National Water-Quality Assessment Program

\title{
Methods to Characterize Environmental Settings of Stream and Groundwater Sampling Sites for National Water-Quality Assessment
}

Scientific Investigations Report 2012-5194 



\section{Methods to Characterize Environmental Settings of Stream and Groundwater Sampling Sites for National Water-Quality Assessment}

By Naomi Nakagaki, Kerie J. Hitt, Curtis V. Price, and James A. Falcone

National Water-Quality Assessment Program

Scientific Investigations Report 2012-5194 


\section{U.S. Department of the Interior \\ KEN SALAZAR, Secretary \\ U.S. Geological Survey \\ Marcia K. McNutt, Director}

U.S. Geological Survey, Reston, Virginia: 2013

For more information on the USGS — the Federal source for science about the Earth, its natural and living resources, natural hazards, and the environment, visit http://www.usgs.gov or call 1-888-ASK-USGS.

For an overview of USGS information products, including maps, imagery, and publications, visit http://www.usgs.gov/pubprod

To order this and other USGS information products, visit http://store.usgs.gov

Any use of trade, product, or firm names is for descriptive purposes only and does not imply endorsement by the U.S. Government.

Although this report is in the public domain, permission must be secured from the individual copyright owners to reproduce any copyrighted materials contained within this report.

Suggested citation:

Nakagaki, Naomi, Hitt, K.J., Price, C.V., and Falcone, J.A., 2013, Methods to characterize environmental settings of stream and groundwater sampling sites for National Water-Quality Assessment: U.S. Geological Survey Scientific Investigations Report 2012-5194, 56 p. 


\section{Foreword}

The U.S. Geological Survey (USGS) is committed to providing the Nation with reliable scientific information that helps to enhance and protect the overall quality of life and that facilitates effective management of water, biological, energy, and mineral resources (http://www.usgs.gov). Information on the Nation's water resources is critical to ensuring long-term availability of water that is safe for drinking and recreation and is suitable for industry, irrigation, and fish and wildlife. Population growth and increasing demands for water make the availability of that water, measured in terms of quantity and quality, even more essential to the long-term sustainability of our communities and ecosystems.

The USGS implemented the National Water-Quality Assessment (NAWQA) Program in 1991 to support national, regional, State, and local information needs and decisions related to water-quality management and policy (http://water.usgs. gov/nawqa). The NAWQA Program is designed to answer" What is the quality of our Nation's streams and groundwater? How are conditions changing over time? How do natural features and human activities affect the quality of streams and groundwater, and where are those effects most pronounced? By combining information on water chemistry, physical characteristics, stream habitat, and aquatic life, the NAWOA Program aims to provide science-based insights for current and emerging water issues and priorities. From 1991 to 2001, the NAWQA Program completed interdisciplinary assessments and established a baseline understanding of water-quality conditions in 51 Nation's river basins and aquifers, referred to as Study Units (http://water.usgs.gov/nawqa/studies/study units.html).

National and regional assessments are ongoing in the second decade (2001-2012) of the NAWQA Program as 42 of the 51 Study Units are selectively reassessed. These assessments extend the findings in the Study Units by determining water-quality status and trends at sites that have been consistently monitored for more than a decade, and filing critical gaps in characterizing the quality of surface water and groundwater. For example, increased emphasis has been placed on assessing the quality of source water and finished water associated with many of the Nation's largest community water systems. During the second decade, NAWQA is addressing five national priority topics that build an understanding of how natural features and human activities affect water quality, and establish links between sources of contaminants, the transport of those contaminants through the hydrologic system, and the potential effects of contaminants on humans and aquatic ecosystems. Included are studies of the fate of agricultural chemicals, effects of urbanization on stream ecosystems, bioaccumulation of mercury in stream ecosystems, effects of nutrient enrichment on aquatic ecosystems, and transport of contaminants to public-supply wells. In addition, national syntheses of information on pesticides, volatile organic compounds (VOCs), nutrients, trace elements, and aquatic ecology are continuing.

The USGS aims to disseminate credible, timely, and relevant science information to address practical and effective water-resource management and strategies that protect and restore water quality. We hope this NAWOA publication will provide you with insights and information to meet your needs, and will foster increased citizen awareness and involvement in the protection and restoration of our Nation's waters.

The USGS recognizes that a national assessment by a single program cannot address all water-resource issues of interest. External coordination at all levels is critical for cost-effective management, regulation, and conservation of our Nation's water resources. The NAWQA Program, therefore, depends on advice and information from other agenciesFederal, State, regional, interstate, Tribal, and local_as well as nongovernmental organizations, industry, academia, and other stakeholder groups. Your assistance and suggestions are greatly appreciated.

William H. Werkheiser Associate Director for Water 


\section{Contents}

Abstract
Introduction.
Puckground

\section{Figures}

1. Maps showing the National Water-Quality Assessment (NAWQA) Program's stream sampling sites and groundwater sampling sites in the conterminous United States

2. Maps showing the stream sampling site and drainage basin boundary for Pudding River at Aurora, Oregon

3. Maps showing the geographic extent of and the location of wells within the Biscayne aquifer in southern Florida.....

4. Example showing the results of simple point overlay of the Pudding River sampling site

5. Example showing the results of simple areal overlay of the Pudding River basin ... 8

6. Simplified examples of estimating quantities and densities by using areal interpolation

7. Example of area-weighted areal interpolation to estimate mean population density for the Pudding River basin

8. Example of area-weighted areal interpolation to estimate population for the Pudding River basin

9. Example of land-cover-weighted areal interpolation to estimate amount of atrazine applied on cultivated crops for the Pudding River basin 


\section{Conversion Factors}

SI to Inch/Pound

\begin{tabular}{lll}
\hline \multicolumn{1}{c}{ Multiply } & \multicolumn{1}{c}{ By } & \multicolumn{1}{c}{ To obtain } \\
\hline centimeter $(\mathrm{cm})$ & Length & \\
meter $(\mathrm{m})$ & 0.3937 & inch (in.) \\
& 3.281 & foot (ft) \\
\hline square kilometer $\left(\mathrm{km}^{2}\right)$ & Area & square mile $\left(\mathrm{mi}^{2}\right)$ \\
\hline & 0.3861 & \\
\hline kilogram $(\mathrm{kg})$ & Mass & pound avoirdupois (lb) \\
\hline
\end{tabular}

Vertical coordinate information is referenced to the North American Vertical Datum of 1988 (NAVD 88).

Horizontal coordinate information is referenced to the North American Datum of 1983 (NAD 83).

Acronyms and Abbreviations

AML Arc Macro Language

GIS geographic information system

LULC Land Use and Land Cover

LUS Land-use study (of shallow ground water)

MAS Major aquifer study

NAWQA National Water-Quality Assessment (program)

NLCD 2001 National Land Cover Database 2001

NLCD 2006 National Land Cover Database 2006

NWIS National Water Information System

RASA Regional Aquifer-System Analysis (study)

STAID station-identification (number)

SSURGO Soil Survey Geographic (database)

STATSGO State Soil Geographic (database)

SUCODE unique identifier for a network of NAWQA sampling sites

Organizations

USGS United States Geological Survey 


\title{
Methods to Characterize Environmental Settings of Stream and Groundwater Sampling Sites for National Water-Quality Assessment
}

\author{
By Naomi Nakagaki, Kerie J. Hitt, Curtis V. Price, and James A. Falcone
}

\section{Abstract}

Characterization of natural and anthropogenic features that define the environmental settings of sampling sites for streams and groundwater, including drainage basins and groundwater study areas, is an essential component of water-quality and ecological investigations being conducted as part of the U.S. Geological Survey's National Water-Quality Assessment program. Quantitative characterization of environmental settings, combined with physical, chemical, and biological data collected at sampling sites, contributes to understanding the status of, and influences on, water-quality and ecological conditions. To support studies for the National Water-Quality Assessment program, a geographic information system (GIS) was used to develop a standard set of methods to consistently characterize the sites, drainage basins, and groundwater study areas across the nation. This report describes three methods used for characterization-simple overlay, area-weighted areal interpolation, and land-cover-weighted areal interpolationand their appropriate applications to geographic analyses that have different objectives and data constraints. In addition, this document records the GIS thematic datasets that are used for the Program's national design and data analyses.

\section{Introduction}

\section{Background}

In 1991, the U.S. Geological Survey (USGS) initiated the National Water-Quality Assessment (NAWQA) Program to assess the quality of our Nation's streams and groundwater. Information analyzed for the NAWQA Program includes chemical concentrations in water, sediment, and aquatic-organism tissues (Gilliom and others, 2001; Gilliom and others, 1995). Over 14 million samples have been collected for the Program at more than 7,700 stream sites and 9,400 wells (U.S. Geological Survey, 2010). The geographic distribution of NAWQA's surface-water and groundwater sites sampled in the conterminous United States is shown in figure 1.
Water-quality findings are used with natural and anthropogenic characteristics for stream and groundwater sampling sites to evaluate how environmental settings affect water quality. For example, high concentrations of atrazine observed at a stream sampling site can correlate with the intense use of atrazine on cropland and poorly drained soils in its drainage basin. Characteristics of sampled sites are not only used to evaluate current water-quality conditions but also in statistical models for predicting concentrations of contaminants in unmonitored areas (Stone and others, 2008; Gilliom and others, 2006; Nolan and Hitt, 2006; Nowell and others, 2006; Stackelberg and others, 2006).

The study design of the NAWQA Program is uniform in its sampling and analytical methods, which makes it equally important to maintain data consistency in compiling site and study-area characteristics. Site and study-area characteristics in the conterminous United States were developed systematically to prevent bias introduced from applying multiple methods and multiple data sources that were compiled differently for a particular characteristic. A GIS was used to construct nationally consistent characteristics by using national geospatial thematic datasets and a standard set of methods.

\section{Purpose and Scope}

The objective of this report is to describe three methods used to characterize the environmental settings of NAWQA's stream and groundwater sampling sites and associated study areas. The three methods are simple overlay, area-weighted areal interpolation, and land-cover-weighted areal interpolation. Fictitious data values are used in most of the examples to simplify the calculations. The methods were incorporated into algorithms by using Esri’s GIS software, originally in Arc Macro Language (AML) for use in the ArcInfo workstation environment, and more recently in Python for use as tools in the ArcGIS Desktop environment. The ArcGIS tools have been published and are documented separately (Price and others, 2010). 


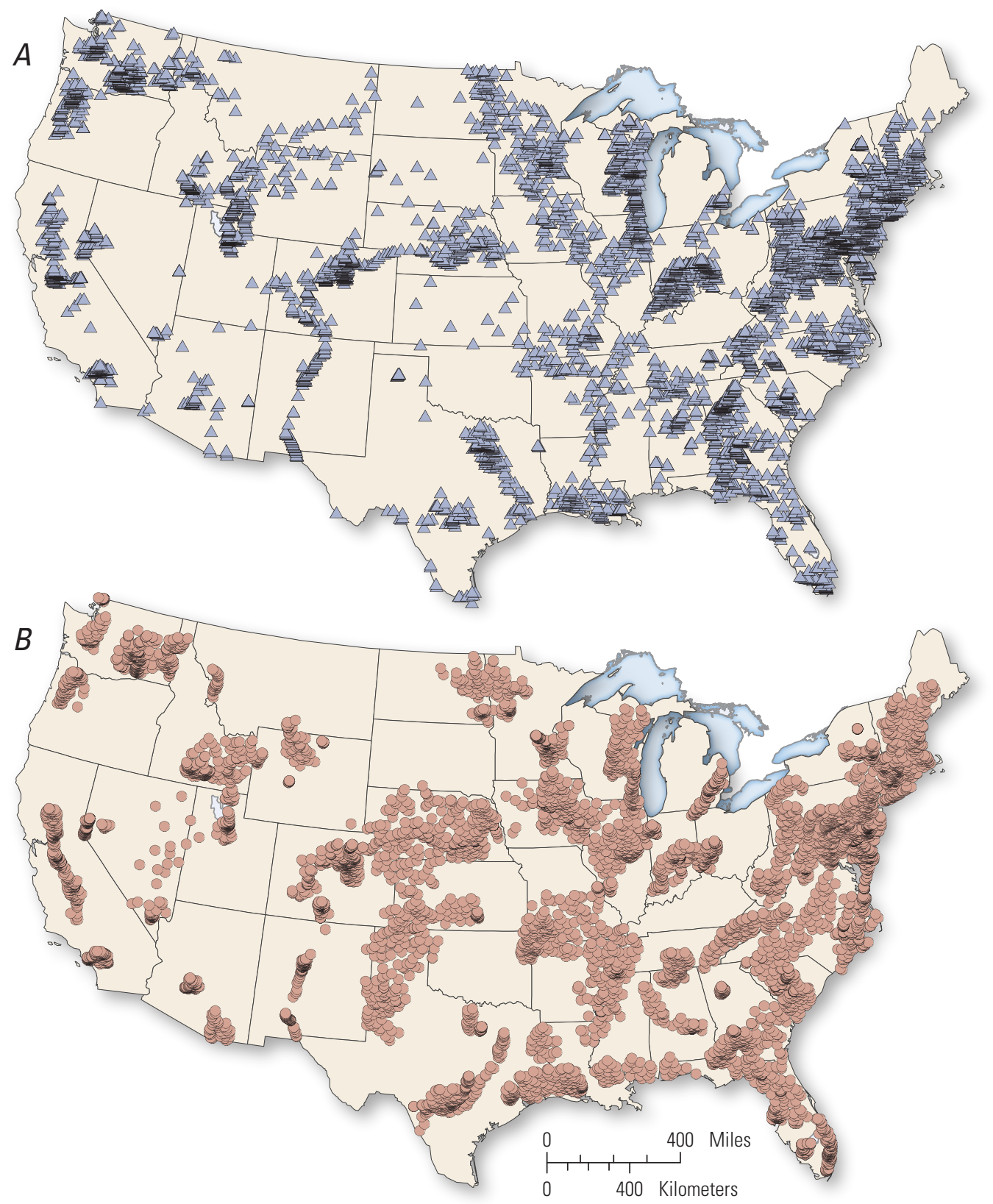

Figure 1. National Water-Quality Assessment (NAWQA) Program's $(A)$ stream sampling sites and $(B)$ groundwater sampling sites in the conterminous United States (U.S. Geological Survey, 2010). These maps are based on the site information data from the NAWQA Data Warehouse (Bell and Williamson, 2006), as of June 3, 2010.

The examples that illustrate the methods use GIS thematic raster data that cover the entire nation. Subsequently, the examples refer to characteristics of raster data, such as grid-cell counts for the conterminous U.S., though the methods can be used with vector data for selected regions. The data format is independent of the method, and the only requirement of the source data is the geographic coverage of the sites and study areas of interest. In the NAWQA Program, it is essential that national thematic datasets be used for characterizing sites and study areas because this helps ensure consistent and comparable characteristics across the country.
The appendix in this report provides descriptions and references for obtaining the national GIS thematic datasets used by NAWQA. It contains over 110 data sources for the conterminous United States and identifies which of the three methods discussed in this report were applied to the dataset. Most of the national GIS thematic datasets were not available for areas outside the lower 48 states; accordingly, NAWQA sampling sites and study areas in Hawaii and Alaska were not characterized. The appendix is a snapshot of the national GIS thematic datasets used by the Program and will likely be updated as newer and enhanced data sources are developed and used for geoprocessing. 


\section{GIS Datasets}

This section describes the GIS datasets used to characterize NAWQA's sampling sites and associated study areas.

\section{Sampling Sites}

NAWQA sampling sites are either specific locations on streams or, in the case of groundwater, specific wells. Each NAWQA sampling site is identified by a station-identification number (STAID), which is the 8-15 digit numeric identifier for the station used within USGS's National Water Information System (NWIS) database (USGS's NWIS web interface is publicly accessible at http://waterdata.usgs.gov/nwis). The latitude and longitude of each NAWQA site, along with other site information stored in NWIS, were used to generate a national GIS point dataset. The environmental characteristics for the stream sampling sites and wells are identified by the USGS STAID.

\section{Drainage Basins}

The drainage basin for a stream sampling site is the topographically defined area of land that potentially contributes runoff to the stream. The stream sampling site and the GIS drainage basin for the USGS station, Pudding River at Aurora, Oregon (STAID 14202000) is shown in figure 2. The drainage basin for this site (hereafter referred to as the "Pudding River basin"), like most other basins, represents the contributing drainage area. Some atypical drainage basins include closed basins — basins that have no natural outlets—or areas that are considered noncontributing except during storms.

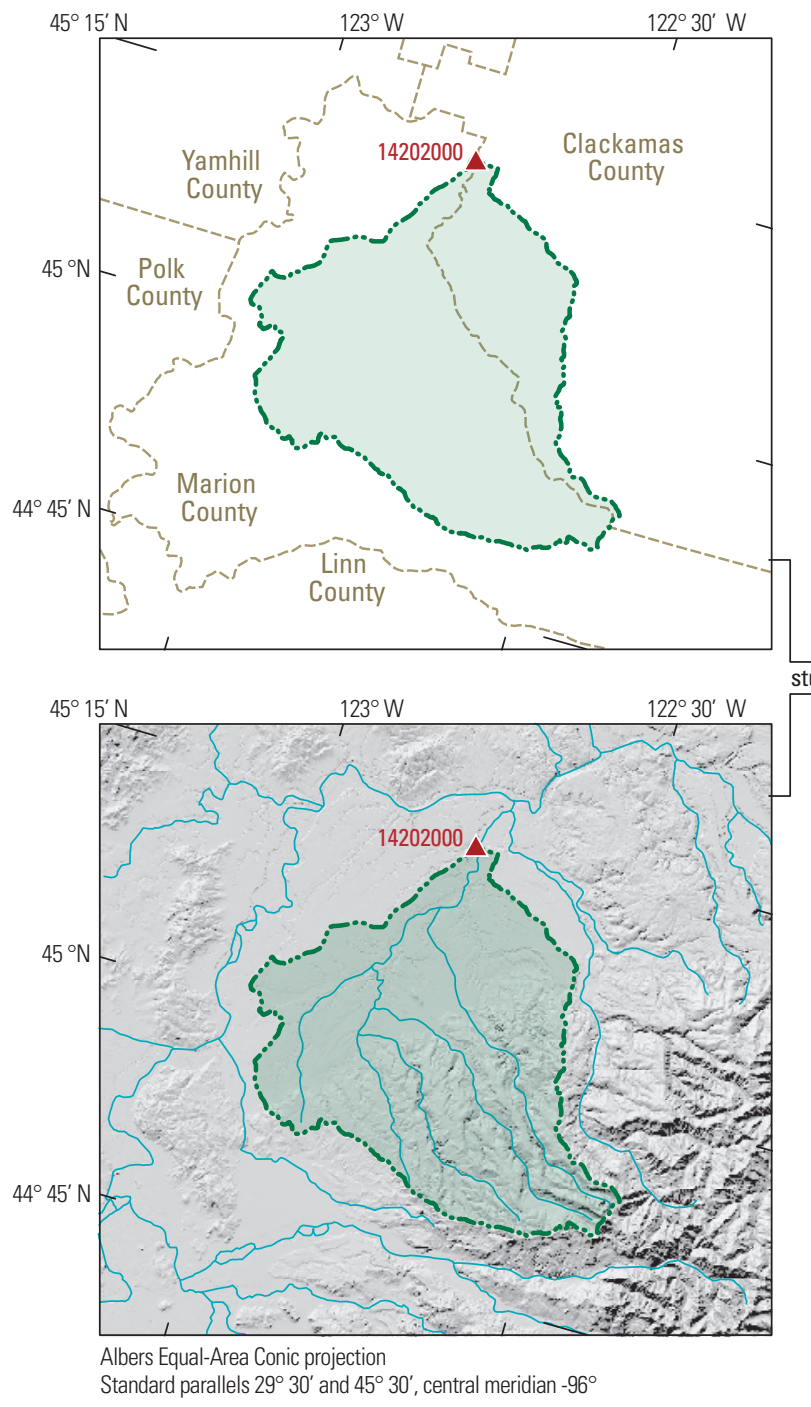

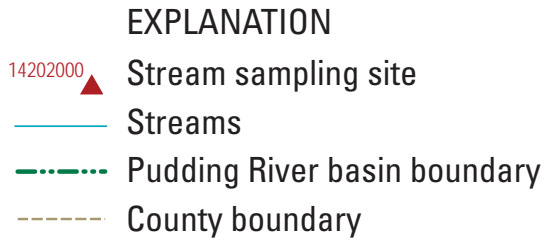

$\overbrace{0}^{0} \quad 10$ Miles

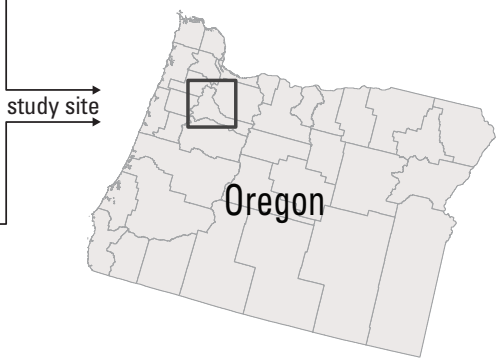

Figure 2. Stream sampling site and drainage basin boundary (Steven Sobieszczyk, U.S. Geological Survey, written commun., 2004) for U.S. Geological Survey's station, 14202000, Pudding River at Aurora, Oregon (U.S. Geological Survey, 2010). Also shown are hydrography (Lanfear, 1991), topography (U.S. Geological Survey, 2003), and county boundaries (National Atlas of the United States, 2005). 
Drainage basins for the NAWQA stream sites were delineated by many USGS hydrologists and geographers from a variety of analog and digital data sources ranging in scale from 1:24,000 to 1:250,000, depending on the size of the basin (Nakagaki, 2010; Nakagaki and Wolock, 2005). The drainage basins, which were originally delineated as vector polygons, were converted to rasters at the 30-meter $(\mathrm{m})$ resolution prior to geoprocessing basin characteristics. Drainage basins for the NAWQA surface-water sampling sites vary greatly in size, ranging from less than one square kilometer $\left(\mathrm{km}^{2}\right)$ to more than $220,000 \mathrm{~km}^{2}$.

A sub-area of the drainage basin, for which a few characteristics are calculated, is defined as the "riparian buffer zone." This sub-area is defined as all areas within 50 or $100 \mathrm{~m}$ of any stream centerline in the basin. The characteristics of the riparian buffer zones as well as the drainage basins are identified by STAID.

\section{Groundwater Study Areas}

NAWQA's groundwater sampling sites (or wells) are characterized in two ways: by buffers around each site and aquifer boundaries linked to groups of wells (or well networks). The circular buffers, which are identified by STAID, are defined by a $500-\mathrm{m}$ radius around the site and have a total area of about $0.78 \mathrm{~km}^{2}$. No provision is made for overlapping buffers; each one is treated separately. NAWQA groundwater sampling sites processed for well networks are characterized by study areas defined by aquifer boundaries or a subarea of the aquifer underlying a targeted land use. Boundaries of aquifers and land-use study areas represent the geographic location of NAWQA's groundwater assessments, and were initially used to constrain the random selection of groundwater sampling sites. NAWQA's groundwater assessments comprise major aquifer studies (MAS) and land-use studies (LUS; Gilliom and others, 1995).

The objective of a MAS is to assess the overall quality of an aquifer that is important for drinking-water supply. The spatial extent of a MAS covers the entire hydrogeologic setting of the aquifer selected for investigation, irrespective of land use. Typically 20-30 wells are randomly selected throughout the aquifer for sampling. For example, the Biscayne aquifer study in southern Florida sampled a network of 30 wells, which provided a broad overview of groundwater quality reflecting a mixture of land uses (fig. 3A). To characterize a MAS, the overall extent of the aquifer selected for study was used as the groundwater study-area boundary (Biscayne aquifer, fig. 3A). The area of a MAS ranged from about $250 \mathrm{~km}^{2}$ to $178,000 \mathrm{~km}^{2}$.

The objective of a LUS is to determine the effects of a certain land use-most frequently agricultural or urban-on predominantly shallow, recently recharged groundwater. This type of study typically involves about 20-30 randomly-selected wells only in areas associated with the land use of interest. For example, a subset of the Biscayne aquifer beneath urban land in Broward County, Florida, was sampled using a network of nearly 40 wells to assess the quality of shallow groundwater within an urban landscape (fig. $3 B$ ). To characterize a LUS, the overall extent of the aquifer selected for study, and the extent of the subset of the aquifer where the targeted land use intersects the aquifer (targeted urban land in Broward County, shown in fig. $3 B$ ), were used as the groundwater study-area boundaries. The area of a LUS ranged from about $20 \mathrm{~km}^{2}$ to $12,700 \mathrm{~km}^{2}$, but most were less than $1,000 \mathrm{~km}^{2}$.

Boundaries of aquifers and land-use study areas within aquifers were delineated by USGS hydrologists and geographers using various geologic, topographic, hydrologic, physiographic, and soils maps (Squillace and Price, 1996). These maps came from many sources, including the Groundwater Atlas of the United States (U.S. Geological Survey, 2000), USGS Regional Aquifer-System Analysis (RASA) studies (Sun and others, 1997), and various land use and land cover datasets. The boundaries of aquifers and land-use study areas, which are often composed of multiple discontinuous areas, were delineated originally as vector polygons then converted to rasters at 30-m resolution prior to geoprocessing for characterization. The characterization of the LUS and MAS well network is identified by an NWIS network name specific to NAWQA networks (SUCODE), which is derived by concatenating the four-letter abbreviation for the NAWQA study area with the code designating a particular groundwater study network.

\section{Thematic Datasets}

The requirements for the GIS thematic datasets for NAWQA are that the data were systematically compiled and are available for the conterminous United States. These requirements are necessary in order to develop consistent characteristics for NAWQA sites and study areas, which span across the nation. To some degree, the exclusive use of national GIS datasets is a limitation because, for some datasets, the national data are less detailed in resolution and attribute information than similar GIS data for regional areas. The geographic extent of all references to "GIS thematic datasets" in this report is the conterminous United States.

The majority of the GIS thematic datasets used by NAWQA are either used in their native form or are slightly modified. The modifications are either changes in the projection and/or conversion from vector to raster format. The format and scale or resolution of the original and revised datasets that are used by NAWQA are included in the appendix. 


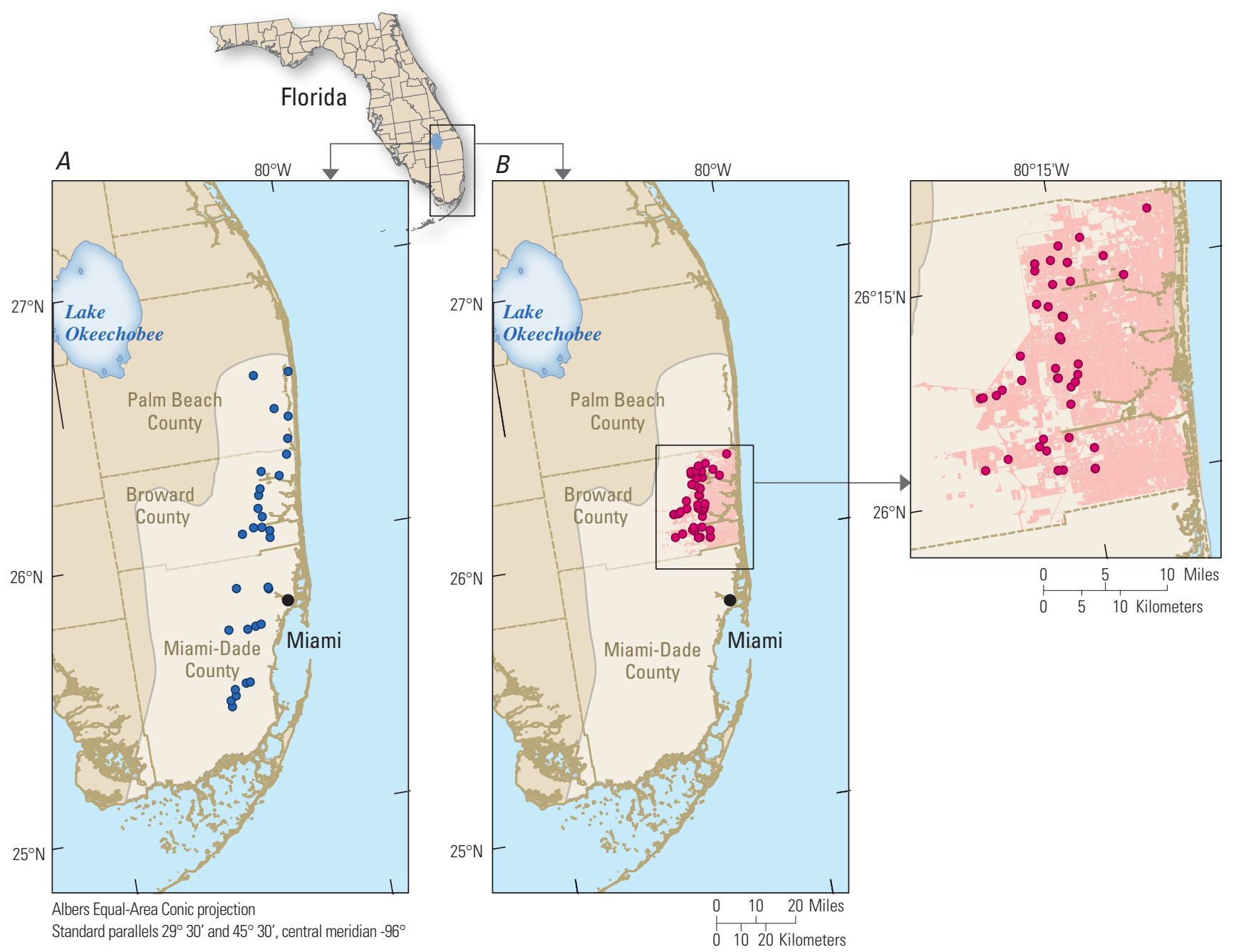

\section{EXPLANATION}

- Well sampled for major aquifer study

Biscayne aquifer

- Well sampled for urban land-use study

County boundary

Biscayne aquifer

Urban (targeted land use)

County boundary

Figure 3. Geographic extent of and the location of wells (U.S. Geological Survey, 2010) sampled in (A) the major aquifer study of the Biscayne aquifer in southern Florida (David S. McCulloch, U.S. Geological Survey, written commun.,1998) and (B) the urban land-use study located within the Biscayne aquifer in southern Florida (David S. McCulloch, U.S. Geological Survey, written commun.,1998). 


\section{Methods}

Geospatial datasets are composed of geographic and attribute information. The geographic component provides the location of the mapped features as point, line, or polygon features ("vector" data) or grid cells ("raster" data), and the attribute component provides characteristics of the mapped features. Mapped features can be represented as "continuous" data—such as elevation represented as continuous surfacesor as "discrete" data—such as land cover represented by definable boundaries.

The attributes of mapped features are stored primarily in two ways: directly in the feature attribute table or indirectly in related data tables. With raster data, the grid cells are identified by their numeric values, which usually represent a single attribute, and the unique values are typically stored in the raster attribute table along with the number of grid cells represented by each value. With vector data, every mapped feature has an associated unique identifier, which is linked to its attributes. The attributes of mapped vector features are commonly stored in the feature attribute table.

For GIS datasets (vector or raster) that consist of a large number of attributes, however, it is generally more efficient to store the attributes in separate, related data tables, or, in other words, multiple tables each linked by a common field or attribute. Often, GIS data structured in this manner consist of mapped areal units that are administrative or political in nature. An example of mapped areal units with attributes stored in related data tables are counties attributed by population and number of housing units.

Multiple methods are used to characterize NAWQA sampling sites and associated study areas depending on the structure of the GIS thematic dataset. In this report, three characterization methods are described: (1) simple overlay, (2) area-weighted areal interpolation, and (3) land-coverweighted areal interpolation. Simple overlay is used with GIS thematic datasets that store attribute information directly associated with each mapped feature (polygon, point, line, or grid cell), whereas areal interpolation is used with GIS thematic datasets in which attribute information is linked to mapped areal units. For all methods, the ArcInfo Workstation GRID commands that set the geoprocessing cell size and "snap grid” were applied to ensure all raster processing was done at 30-m resolution, with all cell locations aligned to the National Land Cover Dataset 1992 (U.S. Geological Survey, 1999; Vogelmann and others, 2001). The method that NAWQA used to process each GIS thematic dataset for NAWQA site and study-area characterization is noted in the appendix.

\section{Simple Overlay}

Simple overlay is the most basic method of characterizing a site or study area. The simple point overlay can be used to overlay (1) point locations, such as the sampling sites with areal features of interest like land cover, or (2) study-area boundaries with point features of interest like dams. The simple line overlay is used to overlay study-area boundaries with linear features of interest, such as roads, whereas the simple areal overlay is used to overlay study-area boundaries with areal features of interest.

Figure 4 shows examples of how a sampling site can be characterized by using simple point overlay. A single overlay of the national NAWQA sampling sites with a national thematic raster results in a table of the categorical or numeric value of the intersecting thematic grid cell for each site. Figure 4A shows the Pudding River at Aurora sampling site superimposed on the 30-m resolution National Land Cover Database 2001 (Homer and others, 2007; U.S. Geological Survey, 2007). The site intersects the land-cover grid cell classified as "woody wetlands," (fig. 4A), and, thus, the site is characterized as such. The same site overlain with the 100-m resolution National Elevation Dataset (U.S. Geological Survey, 2003), is shown in figure $4 B$. The intersecting grid cell has a numeric value of 26 and, thus, is characterized as having an elevation of $26 \mathrm{~m}$.

Simple point overlay can also be used to characterize a study area by the density of point features of interest. The study-area boundary is overlain with the point features, and the results of this overlay provide the tabular data needed to calculate the total number of features within the study area. This number is then divided by the area of the studyarea boundary to determine the feature's density within the study area.

Similarly, simple line overlay can be used to determine the density of linear features of interest within a study area. The process is nearly identical to acquiring the density of point features in a study area: (1) the study-area boundary is overlain with the linear (rather than point) features, (2) the total length (rather than number) of the linear features within the study area is calculated, and (3) the computed total length is divided by the study-area boundary to calculate the feature's density within the study area. 


\section{A Land Cover at Pudding River at Aurora sampling site: Woody wetlands}

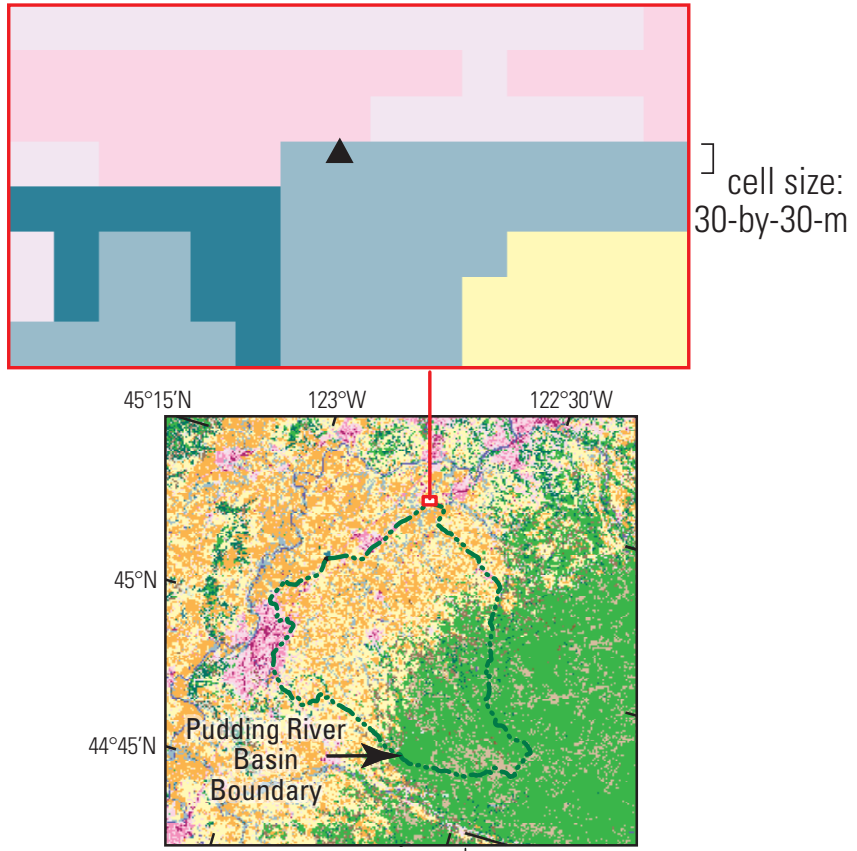

EXPLANATION

\begin{tabular}{l} 
Open water \\
\hline Developed, open space \\
\hline Developed, low intensity \\
Developed, medium intensity \\
Developed, high intensity \\
Barren land \\
Deciduous forest \\
Evergreen forest \\
Mixed forest \\
Shrub/scrub \\
Grasslands/herbaceous \\
Pasture/hay \\
Cultivated crops \\
Woody wetlands \\
Emergent herbaceous wetlands \\
Sampling site
\end{tabular}

\section{$B$ Elevation at Pudding River at Aurora sampling site: 26 m}

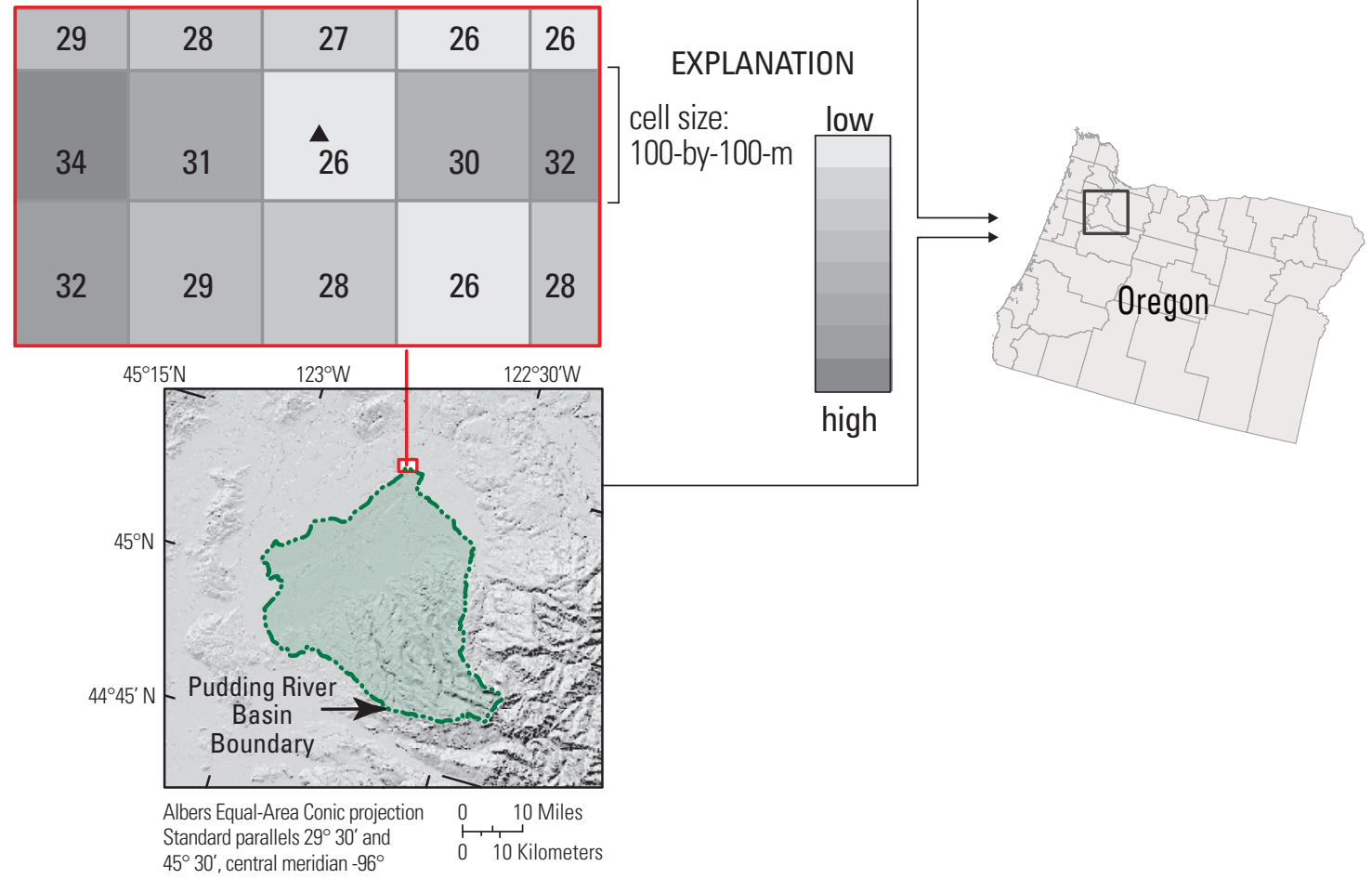

Figure 4. Example showing the results of simple point overlay of the Pudding River sampling site (U.S. Geological Survey, 2010) with $(A)$ a 30-m resolution land-cover raster from the National Land Cover Database 2001 (U.S. Geological Survey, 2007; Homer and others, 2007), and (B) a 100-m resolution elevation raster from the National Elevation Dataset (U.S. Geological Survey, 2003). m, meters. 
To characterize a study area using simple areal overlay, the initial step is to overlay the study-area boundary with area-defined features, and the remaining steps are dependent upon whether the features are discrete or continuous. For discrete data, the study area is characterized as percentages or densities. In contrast, for continuous data, the study area is most often characterized as averages and rarely as total quantities or mass. Simple areal overlay using discrete and continuous data are illustrated in figures $5 \mathrm{~A}$ and $\underline{5 B}$, respectively.

The use of simple areal overlay to characterize land cover in the Pudding River basin is shown in figure $5 \mathrm{~A}$. The 30 -m resolution land-cover raster is overlain with the $30-\mathrm{m}$ resolution raster of the Pudding River basin boundary to generate a land-cover raster for the Pudding River basin. This land-cover raster includes the attribute table of land-cover classification codes (Value) and the number of (30-by-30-m resolution) grid cells (Count) for each land-cover classification in the Pudding River basin. The percentage of the land-cover classifications in the drainage basin is calculated by dividing the number of grid cells represented by each classification by the number of grid cells that define the basin boundary, then multiplying the quotient by 100 . For example, the percentage of “open water" (land-cover code 11) for the Pudding River basin is the number of grid cells in the basin coded as 11 $(7,500)$ divided by the number of grid cells that define the basin $(1,500,000)$, multiplied by 100 , which results in 0.5 .

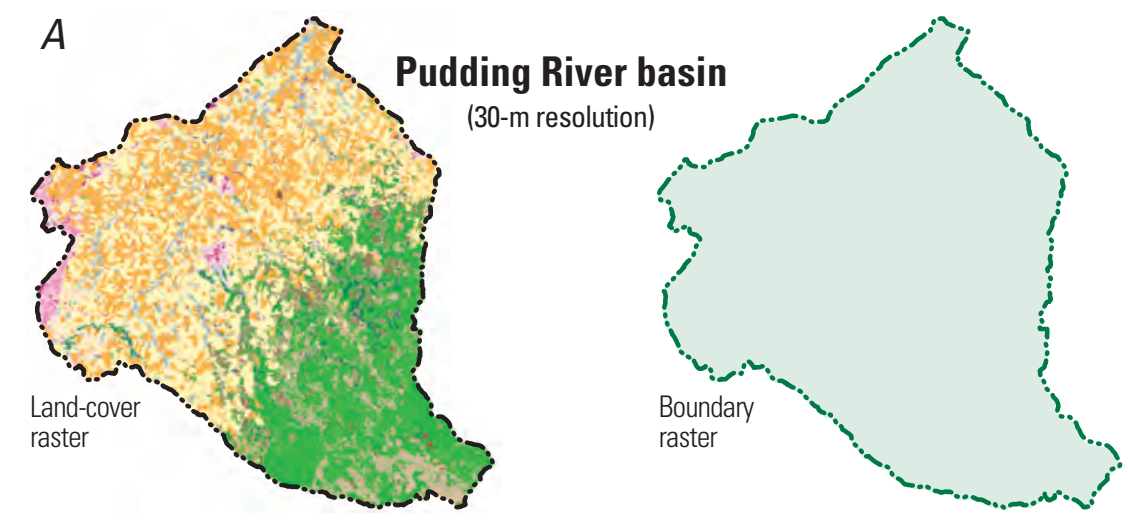

Attribute tables of the land-cover and boundary raster for the Pudding River basin, and derived percentages of land-cover classifications

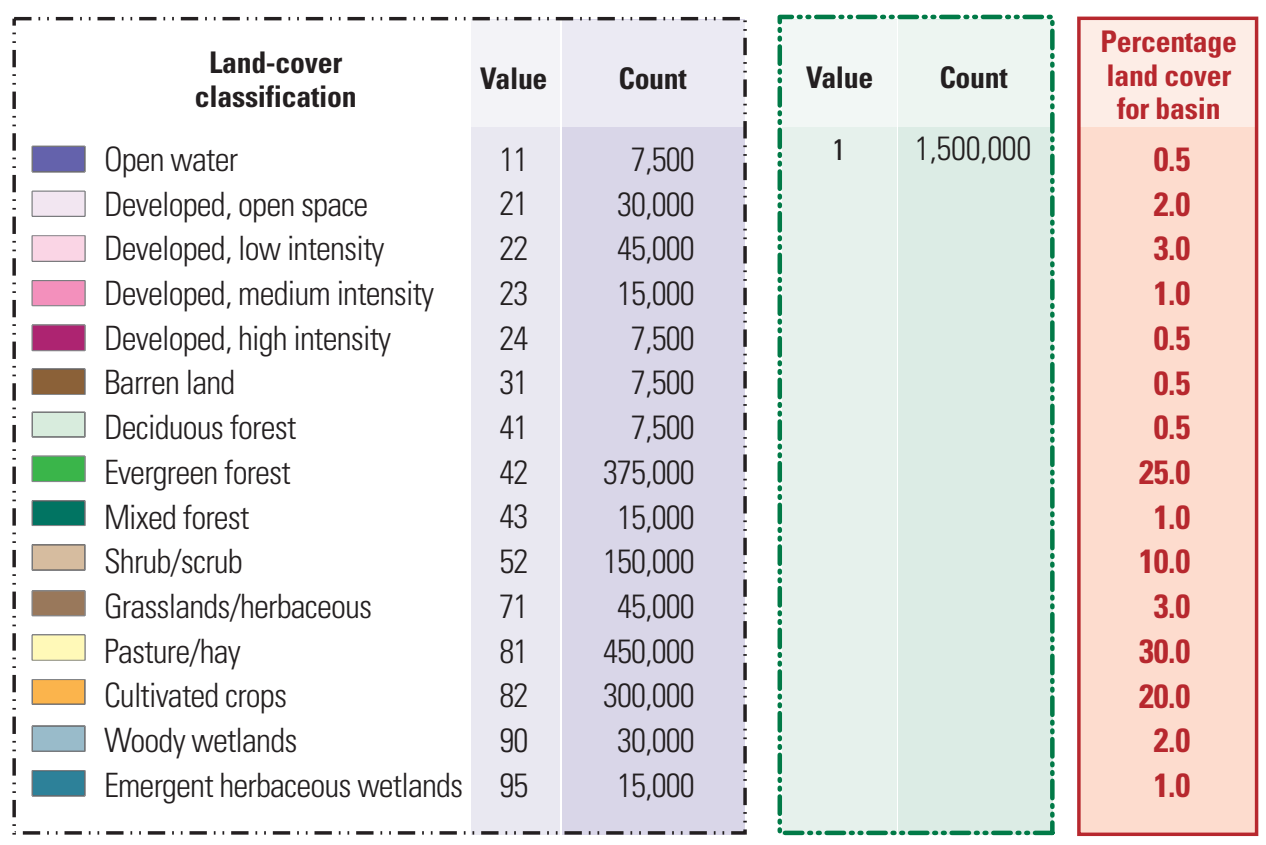

Figure 5. Example showing the results of simple areal overlay of the Pudding River basin with $(A)$ a 30-m resolution land-cover raster from the National Land Cover Database 2001 (U.S. Geological Survey, 2007; Homer and others, 2007) and (B) a 90-m resolution average annual precipitation raster. $\mathrm{cm}$, centimeters; $\mathrm{m}$, meters. 
Pudding River basin boundary raster at the 30-m resolution*

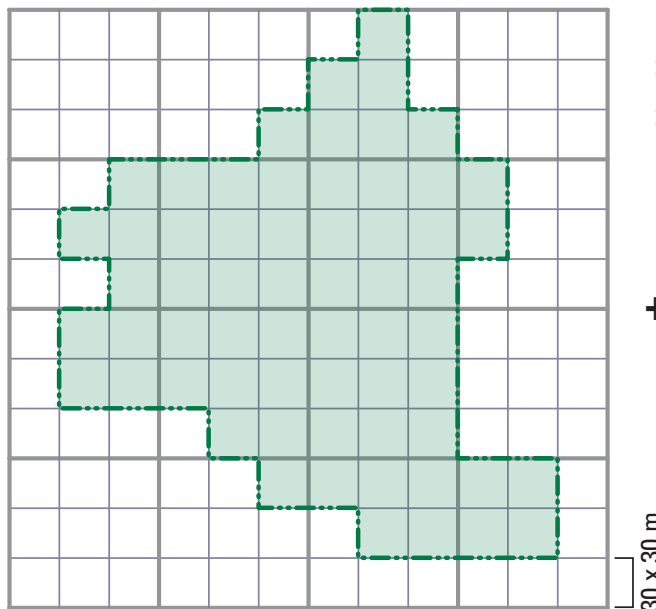

*basin not to scale
Portion of average annual precipitation raster at the $90-\mathrm{m}$ resolution

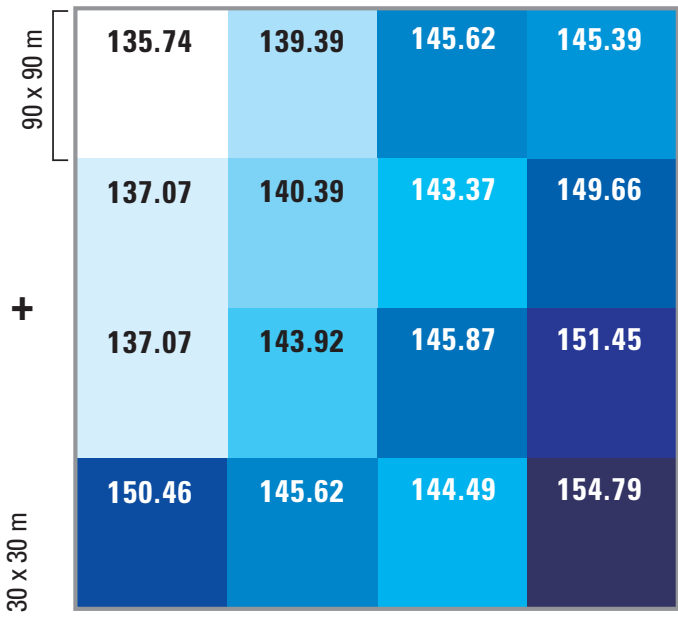

Combined raster of the Pudding River basin boundary raster and the average annual precipitation raster, at the $30-\mathrm{m}$ resolution

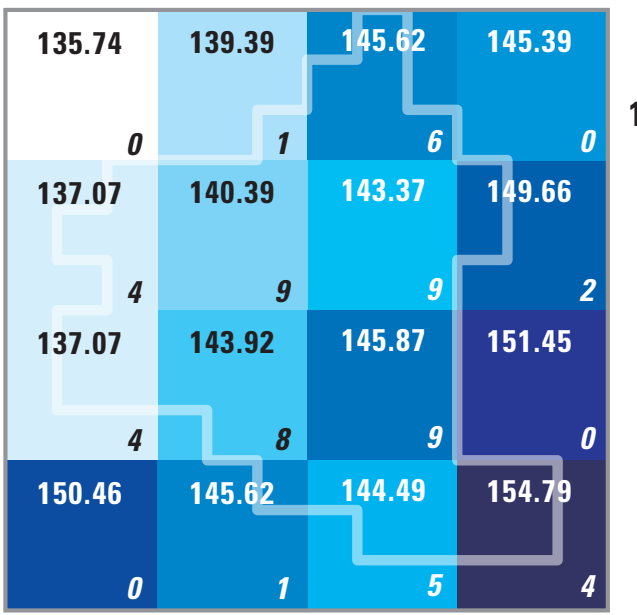

\section{EXPLANATION}

135.74 Precipitation value

0 Number of 30-by-30-m grid cells that contribute to the basin's mean

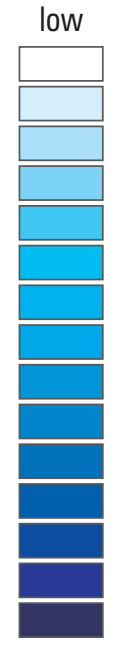

Mean of Average Annual Precipitation for the basin

$=(135.74 \times 0)+(139.39 \times 1)+(145.62 \times 6)+(145.39 \times 0)$

$+(137.07 \times 4)+(140.39 \times 9)+(143.37 \times 9)+(149.66 \times 2)$

$+(137.07 \times 4)+(143.92 \times 8)+(145.87 \times 9)+(151.45 \times 0)$

$\frac{+(150.46 \times 0)+(145.62 \times 1)+(144.49 \times 5)+(154.79 \times 4)}{0+}=\frac{8914.25}{6+}=143.8(\mathrm{~cm})$

$4+9+\quad 9+\quad 2+$

$4+\quad 8+\quad 9+\quad 0+$

$0+1+5+\quad 4$

Figure 5.-Continued 
Figure $5 B$ illustrates simple areal overlay using continuous data, and shows the computations that result when the study area and thematic data rasters have different grid-cell resolutions. In the example, a 90-m resolution (fictitious) precipitation raster is overlain with a $30-\mathrm{m}$ resolution basin boundary raster, and the geoprocessing is set to $30-\mathrm{m}$. Geoprocessing the $90-\mathrm{m}$ resolution precipitation raster at the 30-m resolution results in splitting or

"resampling” each 90-by-90-m grid cell into nine 30-by-30-m grid cells, with each 30-by-30-m grid cell inheriting the value from the (undivided) 90-by-90-m grid cell. Note that only the $30-\mathrm{m}$ resolution precipitation grid cells that overlap the 30-m resolution basin boundary, however, contribute to calculating the mean precipitation for the basin. The top left 90-by-90-m grid cell in figure $5 B$, with a value of 135.74 , does not overlap the 30-m resolution basin boundary, so it does not contribute to computing the mean precipitation for the basin. The 90-by-90-m grid cell below the top left grid cell has four 30-by-30-m (resampled) precipitation grid cells that overlap the basin, so the values of these four grid cells (137.07) contribute to calculating the basin's mean precipitation. This spatial overlay analysis is repeated for each overlapping 30-by-30-m grid cell by the GIS software. The software computes the mean precipitation for the basin by taking the sum of the values of the 30-by-30-m precipitation grid cells that intersect the basin and dividing it by the total number of 30-by-30-m precipitation grid cells that were summed. The computation of the mean average annual precipitation for the Pudding River basin, shown in figure 5B, is 8914.25 divided by 62, or 143.8 (centimeters).

The NAWQA Program processes many 1-km resolution national GIS thematic datasets to calculate study-area means of various features. When the resolution of the thematic dataset (for example, 1-km or 1000-m) does not divide evenly into the processing resolution (such as $30-\mathrm{m}$ ), an uneven resampling of grid cells takes place. In ArcInfo GRID, "nearest-neighbor resampling" occurs by default (which is the setting applied by NAWQA), and the 30-by-30-m resampled thematic data grid cells that partially intersect the basin or study area contribute to its computed mean only if the centroid of these grid cells intersects the 30-by-30-m grid cell of the study area in the same location.

\section{Areal Interpolation}

A common geospatial problem is estimating quantities of an attribute that are defined by mapped areal units that have different boundaries than the study areas of interest. One can acquire crude estimates for the study area by summing the quantities of the attribute corresponding to the mapped areal units, or "source zones," that entirely or partially intersect the study area, or "target zone." While the inclusion of the quantities in their entirety for the partially intersecting source zones would likely produce an overestimation, the exclusion of the quantities for these subdivided source zones would likely produce an underestimation. Instead, the quantities could be refined for the subdivided source zones if areal interpolation were applied to proportion the quantities by the extent of intersection of the source and target zones. In this report, this method is referred to as "area-weighted" areal interpolation.

A simplified example of estimating quantities using area-weighted areal interpolation is shown in figure 6A. There are two fictitious source zones, "X" and "Y," which have a quantity of 6 and 15 units, respectively. Both source zones intersect the target zone (the dotted rectangle), and the quantity that each of these intersecting source zones contributes to the target zone's estimate is dependent upon the fraction of the source zone that intersects the target zone. In this example, the amount of overlap of source zone $\mathrm{X}$ with the target zone is one-sixth, so one-sixth of the quantity associated with source zone X ( 6 units) contributes to the target zone (1 unit). About one-third of source zone $\mathrm{Y}$ intersects the target zone, so one-third of 15, or 5 units of source zone Y contribute to the total quantity for the target zone. The area-weighted total quantity for the target zone then is computed by taking the sum of the contributions from the two source zones ( 1 and 5 units), which is 6 units. Area-weighted areal interpolation assumes that there is homogeneous distribution throughout the source zones.

An approach to improving area-weighted areal interpolation is to use mapped land cover to refine the spatial distribution of the quantified attribute within the source zone. The selected land-cover classification is related to the attribute of interest, for example, mapped residential urban areas and population. Therefore, with land-cover weighted areal interpolation, the spatial distribution of the quantified attribute is confined only to areas that represent the selected land-cover classification. The distribution within these areas is also assumed to be homogeneous.

An example of estimating quantities using land-cover weighted areal interpolation is shown in figure $6 \mathrm{~B}$. The red-colored boxes represent the mapped areas of a specific land-cover classification. The same quantities for source zones $\mathrm{X}$ and $\mathrm{Y}$ depicted in figure $6 \mathrm{~A}$ are now confined to the red boxes in the source zones, such that the red area in source zones $\mathrm{X}$ and $\mathrm{Y}$ has a quantity of 6 and 15 units, respectively ( 7.5 for each red box in source zone Y). One-quarter of the area of the selected land-cover classification in source zone $\mathrm{X}$ intersects with the target zone; therefore, one-fourth of the quantity associated with source zone $\mathrm{X}$ (one-quarter of 6 , or 1.5 units) contributes to the total estimate for the target zone. Because the two areas of the selected land-cover classification in the source zone $\mathrm{Y}$ do not intersect the target zone, the quantities associated with source zone $\mathrm{Y}$ do not contribute to the target zone's estimate. The total quantity for the basin using land-cover weighted interpolation is the sum of the land-cover weighted contributions from source zones $\mathrm{X}$ and $\mathrm{Y}$ $(1.5+0$, or 1.5 units). 

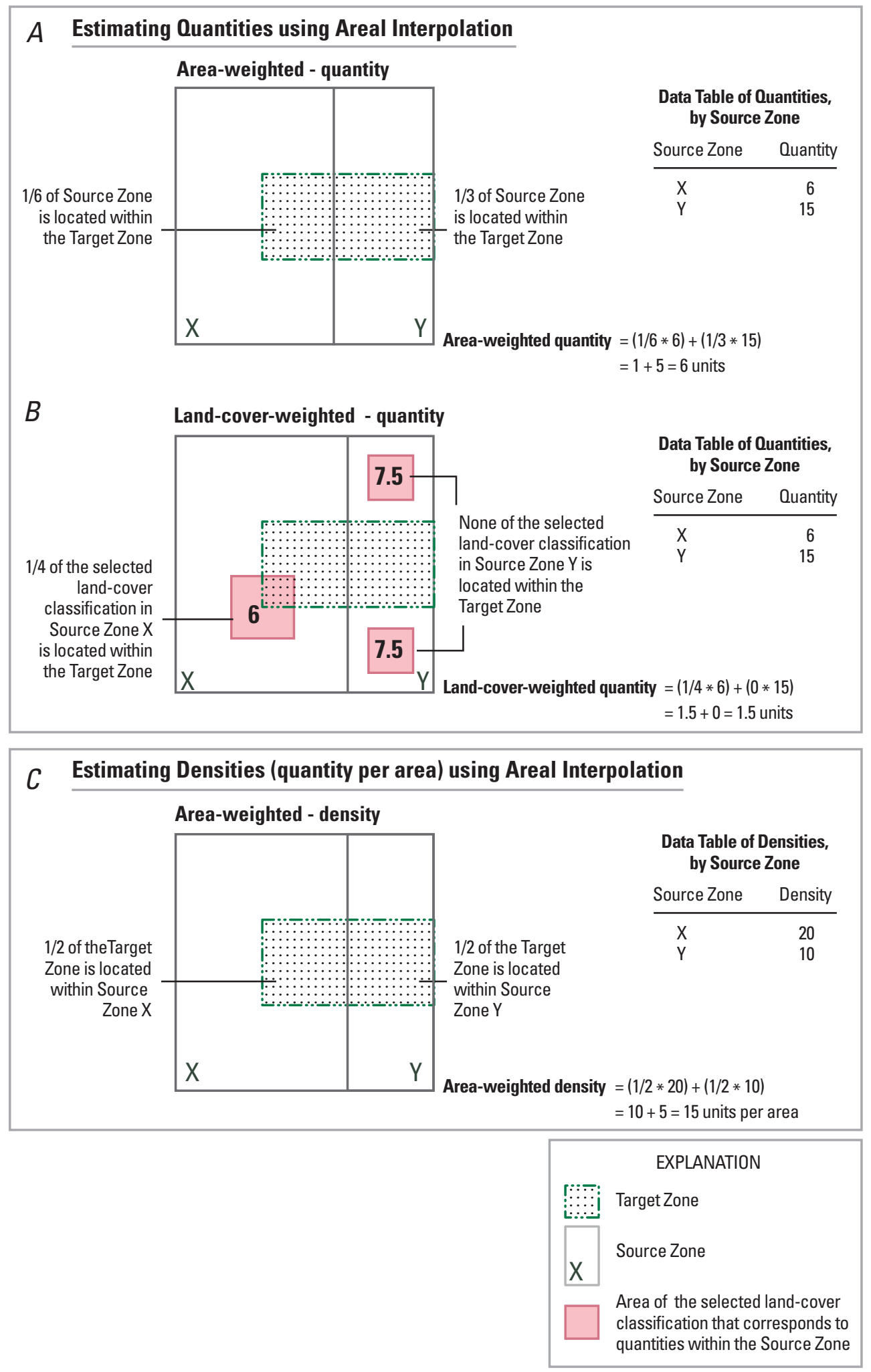

Figure 6. Simplified examples of estimating quantities and densities by using areal interpolation. 
Although the examples in figures $6 \mathrm{~A}$ and $6 \mathrm{~B}$ are fictitious, they show how estimates of quantities can be significantly different depending on the method used to obtain them (by a factor of four). Note that interpolation is unnecessary for a source zone that is entirely within the target zone with either area-weighted or land-cover-weighted areal interpolation because the entire quantity associated with the undivided source zones contributes to the total for the study area. With areal interpolation, in general, the greater amount of overlap that exists between the target and source zones, the higher the probability for more accurate weighted estimates for the subdivided source zones.

For estimating densities, or quantities per unit area, such as mean population density, the intersecting source zone's contribution is based on the percentage of the target zone intersecting each source zone. The percentage is applied to the density associated with the entire source zone to quantify the contribution from each intersecting source zone. Thus, if 80 percent of the target zone overlaps a source zone, then 80 percent of the density associated with this source zone contributes to the density of the target zone. This approach also assumes the density of the attribute is uniform across the source zones.

An example of applying area-weighted interpolation to determine an area-weighted mean density is depicted in figure 6C. As with the examples in figures $6 A$ and $\underline{6 B}$, source zones $\mathrm{X}$ and $\mathrm{Y}$ intersect the target zone; however, in figure $6 \mathrm{C}$, 20 and 10 are the associated attribute densities for the two source zones, respectively. Because half of the target zone lies in each of the two source zones, half of the density associated with source zone X (20) contributes to the weighted mean for the target zone ( 0.5 multiplied by 20 , or 10 ) and half of the density associated with source zone $\mathrm{Y}(10)$ contributes to the weighted mean for the target zone ( 0.5 multiplied by 10 , or 5$)$. The sum of the weighted means (10 and 5, respectively), or 15 units per area, is the resulting weighted mean density for the target zone.

The following two sections walk through step-by-step calculations for estimating mean densities and total quantities of an attribute for a study area using area-weighted areal interpolation, and estimating total quantities (or masses) of an attribute derived from land-cover weighted areal interpolation. Hereafter, the estimates derived for total quantities and mean densities using area-weighted areal interpolation are referred to as "area-weighted quantities" and "area-weighted mean densities," respectively; the estimates computed for quantities using land-cover weighted interpolation are referred to as "landcover weighted quantities."

\section{Area-Weighted Areal Interpolation}

Area-weighted areal interpolation is used to estimate mean densities and quantities of an attribute. The process of estimating the mean density of an attribute for a target zone (Dt) can be summarized as follows:

$$
\sum_{i=1}^{n}\left(\frac{A s t_{i}}{A t} * D s_{i}\right)
$$

where

$n$ is number of source zones (for example, counties) intersecting the target zone (for example, drainage basin),

Ast $_{i}$ is Area of intersection, of source zone $i$ and the target zone,

At is Area of the target zone, and

$D s_{i}$ is Density of an attribute expressed in units per area, for source zone $i$.

The use of area-weighted areal interpolation to estimate the area-weighted mean (or the weighted average) population density for the Pudding River basin using county boundaries and (fictitious) population density values is illustrated in figure 7. Here, the target zone is the Pudding River basin and the source zones are counties, for which there are population density statistics. The method is presented in 4 steps (fig. 7):

1. determine the areas of intersection of the source zones with the target zone (Ast), and determine the area of the target zone $(A t)$;

2. calculate the area-weighted weighting factors for the source zones that intersect the target zone (WF);

3. calculate the area-weighted densities of the attribute for the source zones that intersect the target zone (Dst); and

4. sum the area-weighted densities (Dst) to calculate the area-weighted mean density of the attribute for the target zone $(D t)$.

Step 1 has two parts. The first part of step 1 (fig. 7 , step $1 \mathrm{~A}$ ) is to determine the areas of intersection of the source zones (counties) with the target zone (Pudding River basin). To compute these areas, the raster of the Pudding River basin boundary is overlain with the national raster of county boundaries. The results from this raster overlay yield the number of grid cells (and thus the areas) of the Pudding River basin that intersect each county. In this example, the basin intersects two counties, Clackamas and Marion (referred to as counties " $A$ " and "B," respectively), and the areas of the counties intersecting the basin are 300 and $900 \mathrm{~km}^{2}$, respectively. The second part of step 1 (fig. 7, step $1 B$ ) is to determine the area of the target zone. Derived from the number of grid cells that define the basin boundary, the area of the Pudding River basin is shown to be $1,200 \mathrm{~km}^{2}$.

Next, step 2 (fig. 7, step 2) calculates the area-weighted weighting factors for the source zones that intersect the target zone. This weighting factor is equal to the area of intersection of the source zone with the target zone, divided by the area of the target zone. In this example, the weighting factor for county A is $300 \mathrm{~km}^{2}$ divided by $1200 \mathrm{~km}^{2}$, or 0.25 ; for county $\mathrm{B}$, it is $900 \mathrm{~km}^{2}$ divided by $1,200 \mathrm{~km}^{2}$, or 0.75 . 

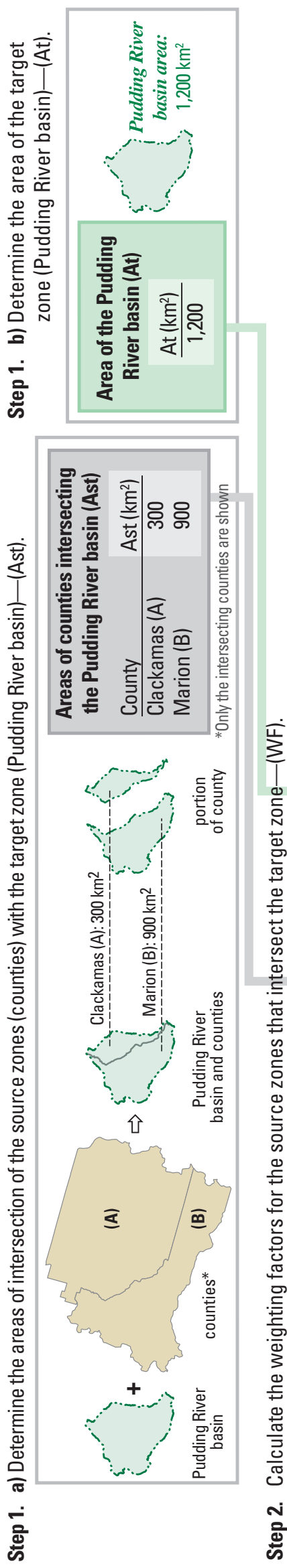
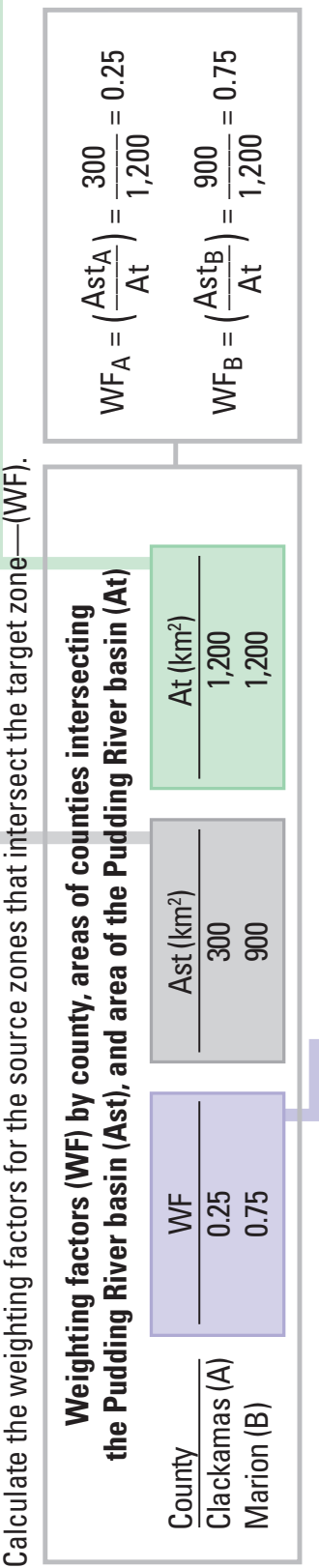

के

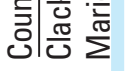

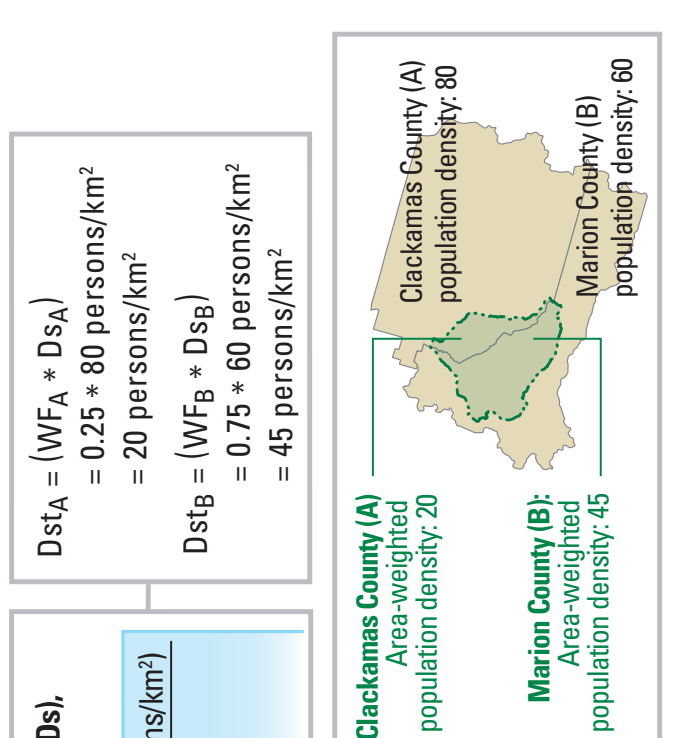

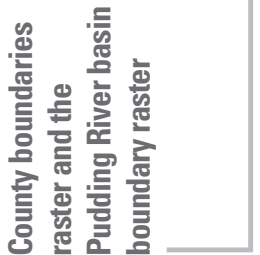

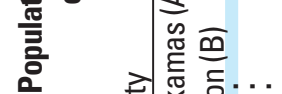

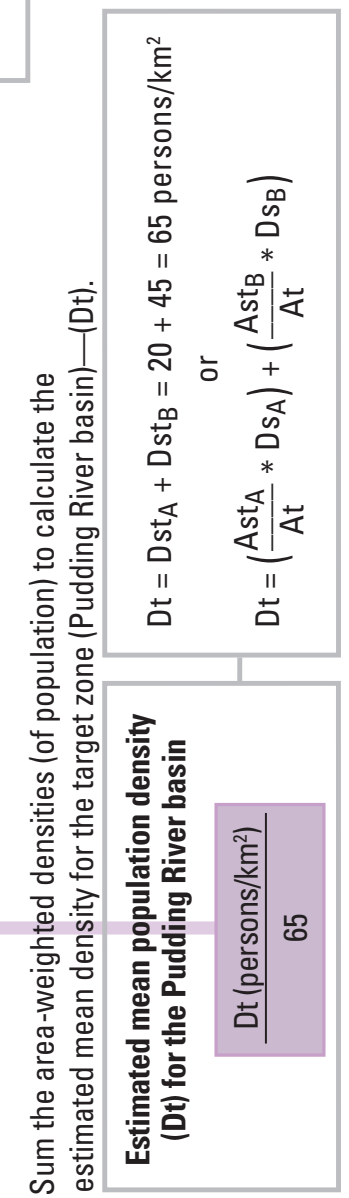

के $\stackrel{0}{\simeq}$

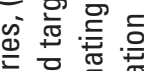

票焉产

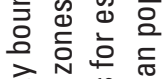

空必

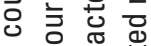

낭 क

ब声言

닌

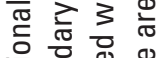

吾喜 卷 증 융 三 覀券产 믿ำ क⿻

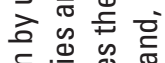

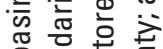
을 㐫定夜 줄

毫言皆

응 $\pi$ 요웡 F六范

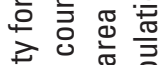

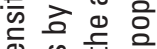
क्षे क्ष

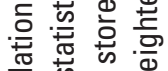
高就交

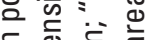

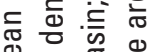

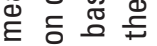
就

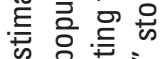
क 웡 을 .들 元婂.

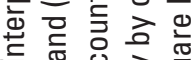

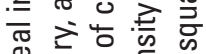

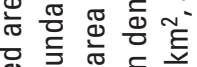

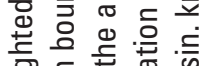

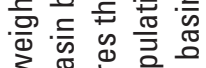

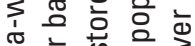
बँ के

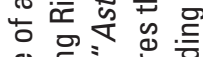
응 흠

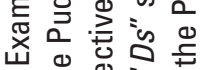

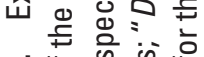
กับ

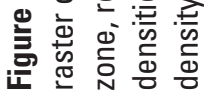


In step 3 (fig. 7, step 3), the area-weighted density of the attribute (population) is determined for the source zones that intersect the target zone by multiplying the weighting factor for the source zone by the density for the source zone. Given that the countywide population densities for counties A and $\mathrm{B}$ are 80 and 60 persons $/ \mathrm{km}^{2}$, respectively, the weighted population density estimates for the portions of these two counties in the Pudding River basin are 0.25 multiplied by 80 persons $/ \mathrm{km}^{2}$, or 20 persons $/ \mathrm{km}^{2}$, and 0.75 multiplied by 60 persons $/ \mathrm{km}^{2}$, or 45 persons $/ \mathrm{km}^{2}$, respectively.

Finally, in step 4 (fig. 7, step 4), the estimated area-weighted density of the attribute (population) for the target zone (Pudding River basin) is computed by summing the weighted densities (of population) calculated in the previous step. The sum of the weighted densities for counties A and B (20 and 45 persons $/ \mathrm{km}^{2}$ ) is 65 persons $/ \mathrm{km}^{2}$.

The process of estimating quantities of an attribute for a target zone by using area-weighted areal interpolation $(Q t)$ can be summarized as follows:

$$
\sum_{i=1}^{n}\left(\frac{A s t_{i}}{A s_{i}} * Q s_{i}\right)
$$

where

$n$ is number of source zones (for example, counties) intersecting the target zone (for example, drainage basin),

Ast $_{i}$ is Area of intersection, of source zone $i$ with the target zone,

$A s_{i}$ is Area of the source zone $i$, and

$Q s_{i}$ is Quantity of an attribute for source zone $i$.

Equations 1 and 2 have important differences: the divisor in equation 1 represents the area of the target zone, whereas the divisor in formula 2 represents the area of the source zone. In other words, the only variation lies in the computation of the weighting factor. Accordingly, the steps to compute area-weighted quantities are nearly identical to the steps to compute area-weighted mean densities. The step-by-step process to estimate population for the Pudding River basin using area-weighted areal interpolation from county boundaries and (fictitious) county areas and population statistics is illustrated in figure 8 .

The initial step in this approach determines the areas of intersection of the source zones with the target zone (fig. 8, step $1 A$ ), which is identical to figure 7 step $1 A$; however, the second part (fig. 8, step $1 B$ determines the area of the source zones (counties) rather than the target zone. Derived from the number of grid cells for each county in the national raster of county boundaries, the areas of Clackamas and Marion counties (counties " $A$ " and "B," respectively) are 5,000 km² and 3,000 $\mathrm{km}^{2}$, respectively. (Note: this step only needs to be carried out a single time to obtain the source-zone areas for the entire nation.)
Next, step 2 (fig. 8, step 2) calculates the weighting factors for estimating quantities for the source zones (counties) that intersect the target zone. The weighting factor is equal to the area of intersection of the source zone with the target zone, divided by the total area of the source zone. In this example, the weighting factor for county A is $300 \mathrm{~km}^{2}$ divided by the countywide area, $5,000 \mathrm{~km}^{2}$, or 0.06 ; and, similarly, the weighting factor for county B is $900 \mathrm{~km}^{2}$ divided $3,000 \mathrm{~km}^{2}$, or 0.30 .

In step 3 (fig. 8, step 3), the weighted quantity of the attribute (population) for a source zone that intersects the target zone is determined by multiplying the weighting factor for a source zone by the quantity (population) for the source zone (county). Given the populations for counties A and B are 250,000 and 210,000 persons, respectively, the weighted populations for these two counties are 0.06 multiplied by 250,000 persons, or 15,000 persons, and 0.3 multiplied by 210,000 persons, or 63,000 persons, respectively.

Finally, in step 4 (fig. 8, step 4), the quantitative estimate of the attribute (population) for the target zone (Pudding River basin) is computed by summing the weighted quantities of the attribute (population) calculated in the previous step. The weighted population for counties A and B, 15,000 and 63,000 persons, respectively, are summed, which is 78,000 persons. Population density could then be calculated by dividing the 78,000 persons by the area of the basin, $1,200 \mathrm{~km}^{2}$, which is 65 persons $/ \mathrm{km}^{2}$.

It is worth noting that if a national raster of population density or population counts was readily available, simple overlay could be used instead of areal interpolation. The population density raster could be superimposed over a basin boundary raster, for example, and the mean of the population density values of the overlapping grid cells would reflect the mean population density for the basin. Similarly, a population (counts) raster could be superimposed over the basin boundary raster, and the sum of the population values of the overlapping grid cells would reflect the total population for the basin. In addition, this total population estimate divided by the basin area would represent the mean population density for the basin.

Two factors are important to consider when deciding whether to use simple overlay or areal interpolation if the option exists: the resolution of the raster data for the attribute of interest, and the size of the source and target zones. A raster of population density or population counts with large grid cells (for example, 5 kilometers by 5 kilometers) would be too coarse to characterize a number of small drainage basins (for example, less than $25 \mathrm{~km}^{2}$ ). Results could be improved by applying area-weighted interpolation using detailed source-zone boundaries rasterized at a higher resolution (smaller grid cells). Furthermore, estimating population density or population (counts) using smaller source zones (such as census blocks rather than counties) would greatly improve estimates for the partially intersecting source zones. If, however, either method could be applied, but there were a large number of source-zone level attributes of interest, it would be more efficient to employ areal interpolation instead of simple overlay to obtain study-area characteristics. 


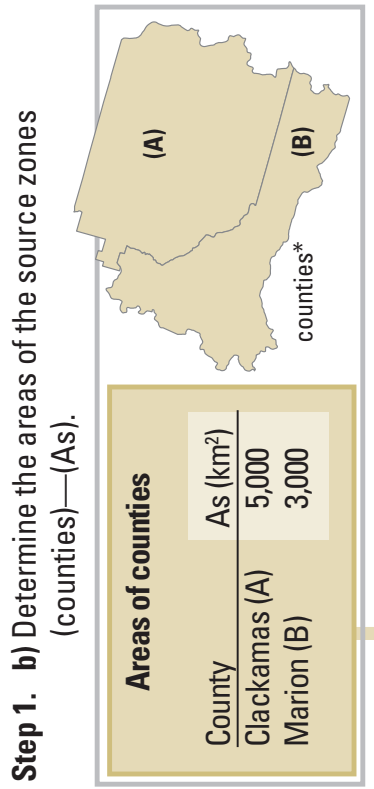

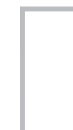
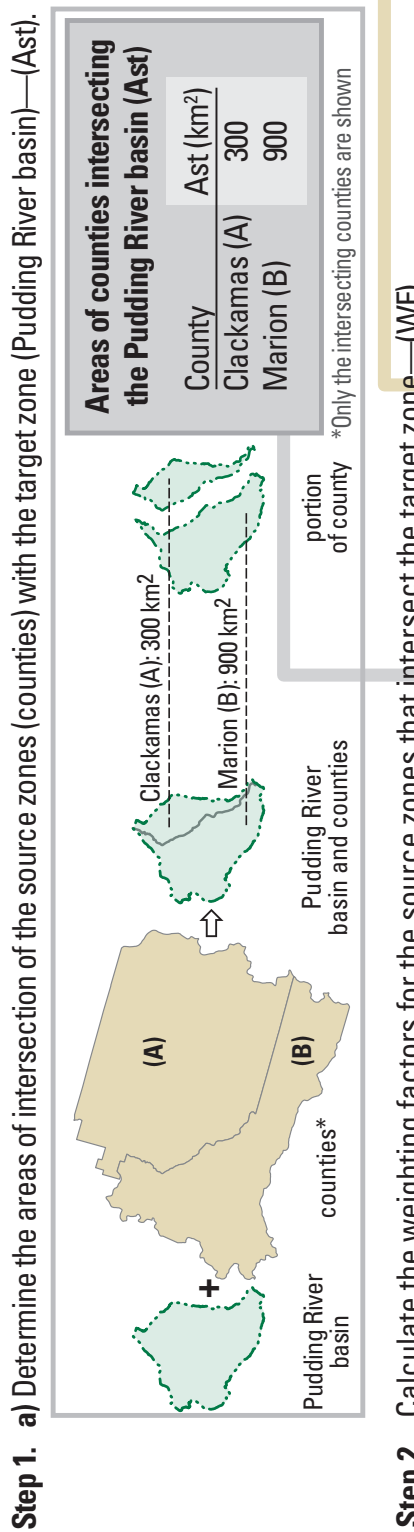

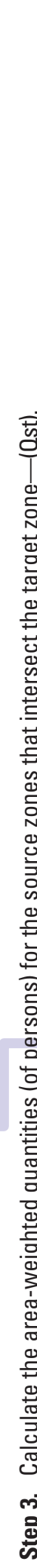

$\stackrel{0}{\rightleftarrows}$

은 这

क

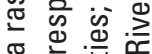

전

过 금

늠

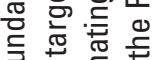

응 흘흘

उ。

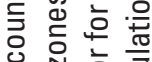

눙

む) 늉

范

닝

흫ㅎㅁ

흐 일 히

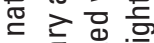

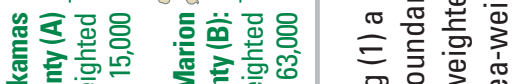

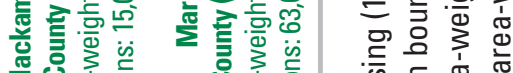

क⿹

그요

등

政

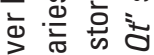

는 든 흘

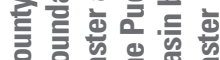

\& $\quad$ i $\frac{\pi}{0} \sum^{\pi}$

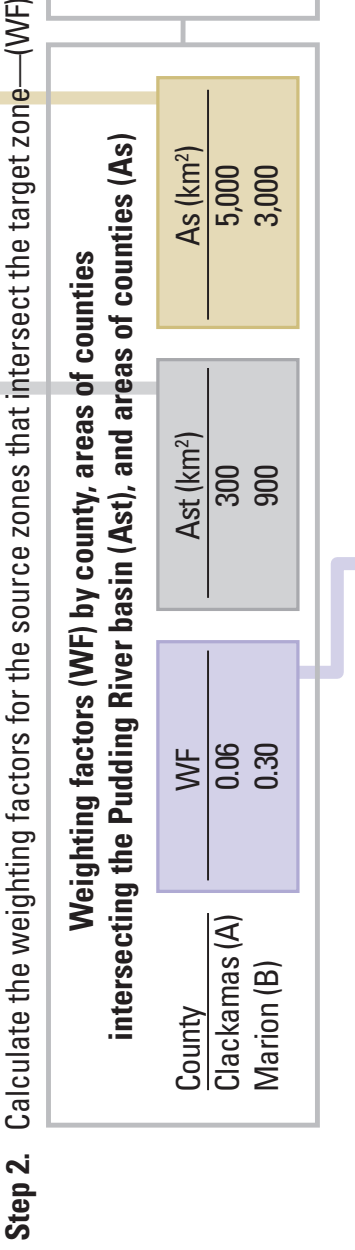

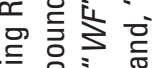

흥 辡

๙

효요

등

은 矛

흥 00 оे

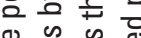

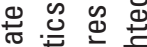

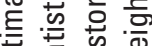

要

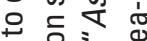

드유

范

응흥응

琼

$\cong$ 음 운

元

夜

产离

휴 등 \&

文莣

đ đ

㐫言范.

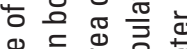

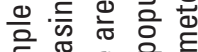

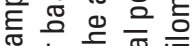

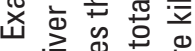

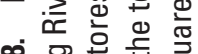

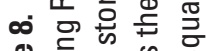

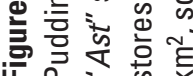


With areal interpolation, in general, the map overlay, which is the most computationally-intensive step, is conducted once to determine the weighting factors, and the remaining processing consists of simple tabular computations of any number of variables. If, for example, characteristics for drainage basins located throughout the U.S. were needed for dozens of census variables, simple overlay would require a map overlay of the basin boundary with each national raster of the census variables. The use of areal interpolation instead of simple overlay for characterizing numerous variables by source zones reduces processing time and avoids data duplication.

\section{Land-Cover-Weighted Areal Interpolation}

Land-cover-weighted areal interpolation is an extension of area-weighted areal interpolation in which land cover is added to refine the spatial interpolation process. Rather than distributing a quantified attribute uniformly throughout the source zone, the attribute is confined to areas representing selected land classifications that have a direct association with the attribute. The addition of ancillary data for areal interpolation, which has been referred to as "dasymetric mapping," has been used to estimate population using census geography and urban land cover from classified satellite imagery (Riebel and Agrawal, 2007; Holt and others, 2004; Fisher and Langford, 1996).

Although any single land classification or groupings of classifications can be used with land-cover-weighted areal interpolation, the following discussion and example illustrate the method applied to cropland. The process of estimating quantities of an attribute for a target zone by using land-coverweighted areal interpolation $(Q L t)$ can be summarized as follows:

$$
\sum_{i=1}^{n}\left(\frac{A L s t_{i}}{A L s_{i}} * Q s_{i}\right)
$$

where

$n$ is number of source zones (for example, counties) intersecting a target zone (for example, drainage basin),

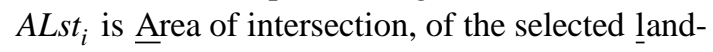
cover classification (for example, cropland) within source zone $i$ and the target zone,

$A L s_{i}$ is Area of the selected land-cover classification in the entire source zone $i$, and

$Q s_{i}$ is Quantity of an attribute for source zone $i$.

Equations 2 and 3 have one difference: in equation 2, the areas $\left(A s t_{i}\right.$ and $\left.A s_{i}\right)$ pertain to the source zones in general and, in equation 3 , the areas $\left(A L s t_{i}\right.$ and $\left.A L s_{i}\right)$ pertain to the areas of land-cover classifications within the source zones.
The implementation of land-cover-weighted areal interpolation is illustrated in figure 9. The example shows how it can be used to estimate the amount of atrazine applied on cultivated crops in the Pudding River basin by using (fictitious) atrazine-use values and areas of cropland. In this example, the Pudding River basin is the target zone, the counties are the source zones, estimated amount of atrazine use on crops by county is the quantitative attribute for the source zones, and "cultivated crops" is the selected land-cover classification. The source for mapped cropland is the National Land Cover Database 2001 or “NLCD 2001” (U.S. Geological Survey, 2007; Homer and others, 2007).

The first part of step 1 (fig. 9 , step $1 A$ ) is to determine, by source zone (county), the total area of the selected land classification, "cultivated crops," located within the target zone (Pudding River basin). These areas are obtained by overlaying the raster of the Pudding River basin boundary with the national rasters of land cover and county boundaries. The results from these overlays yield the county areas of cropland in the basin: for Clackamas county (county " $\mathrm{A}$ "), the total area of land classified as "cultivated crops" within the basin is the $75 \mathrm{~km}^{2}$; for Marion county (county "B"), the total area is $200 \mathrm{~km}^{2}$.

The second part of step 1 (fig. 9, step $1 B$ ) is to determine the source-zone (countywide) areas of the selected land classification ("cultivated crops"). These areas are acquired by overlaying the national land-cover raster with the national county boundaries raster. The countywide area of "cultivated crops" for counties A and B are $300 \mathrm{~km}^{2}$ and $500 \mathrm{~km}^{2}$, respectively. (Note: this step is required only once to obtain the source-zone areas of the selected land cover for the entire nation.)

Figure 9. Example of land-cover-weighted areal interpolation to estimate amount of atrazine applied on cultivated crops for the Pudding River basin by using (1) a 30-m resolution landcover raster from the National Land Cover Database 2001 or "NLCD 2001" (U.S. Geological Survey, 2007; Homer and others, 2007), (2) a national raster of county boundaries, (3) a raster of the Pudding River basin boundary, and (4) fictitious county atrazine use estimates on cultivated crops. The county boundaries and basin boundary are the source zones and target zone, respectively. "ALst" stores the area of land classified as "cultivated crops" in the NLCD 2001 located within the Pudding River basin, by county; "ALs" stores the countywide area of land classified as "cultivated crops" in the NLCD 2001, by county; "WF" stores the land-cover weighted weighting factor for quantifying totals; " $Q s$ " stores the atrazine use value for the county; " $Q s t$ " stores the weighted value of atrazine for the county; and " $Q t$ " stores the land-cover-weighted total mass of atrazine use for the Pudding River basin. $\mathrm{km}^{2}$, square kilometer; $\mathrm{kg}$, kilograms. Shown on next page. 
Step 1 a) Determine by source zone (county), the total areas of the selected land classification ("Cultivated crops") located within the target zone (Pudding River basin)—(ALst).

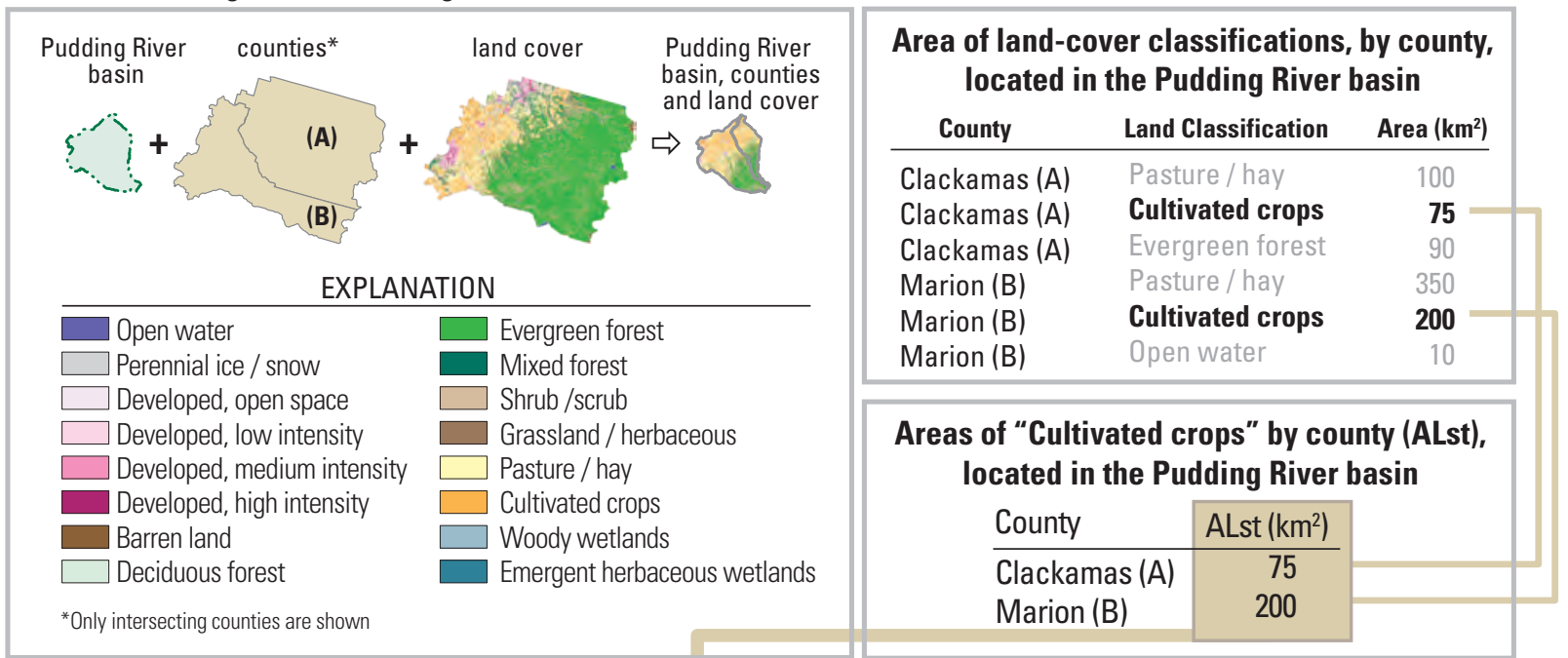

Step 1 b) Determine the source-zone-level (countywide) areas of the selected land classification ("Cultivated crops")—(ALs).

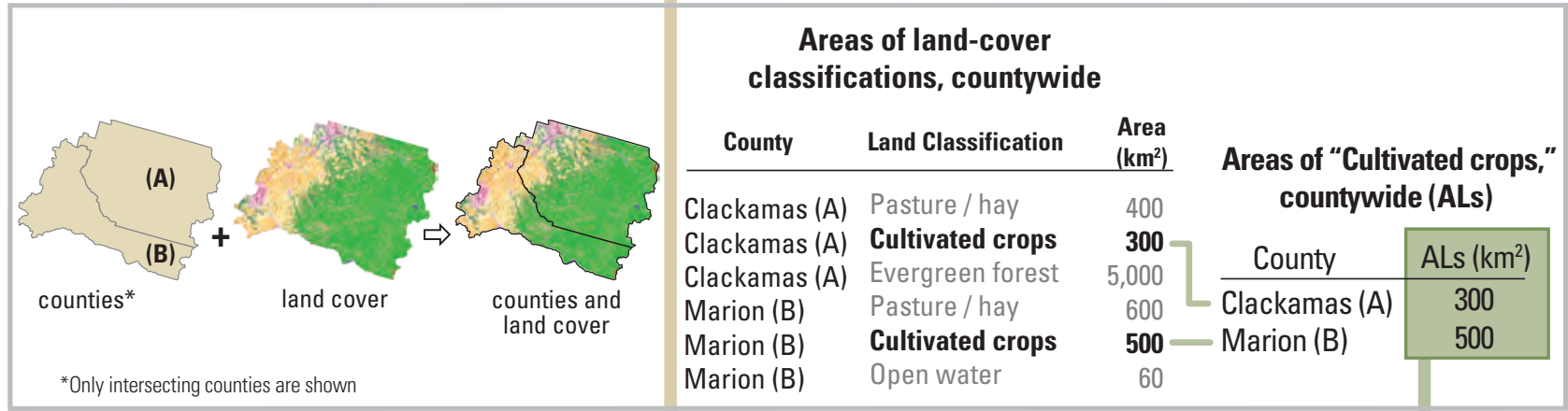

Step 2 Calculate the weighting factors for the source zones that intersect the target zones-(WF).

\begin{tabular}{|c|c|c|c|c|}
\hline \multicolumn{4}{|c|}{$\begin{array}{l}\text { Weighting factors (WF), areas of "Cultivated crops" within the Pudding } \\
\text { River basin (ALst), and areas of "Cultivated crops," countywide (ALs) }\end{array}$} & $W F_{A}=\left(\frac{A L s t_{A}}{A L s_{A}}\right)=\frac{75}{300}=0.25$ \\
\hline County & WF & ALst $\left(\mathrm{km}^{2}\right)$ & $\mathrm{ALs}\left(\mathrm{km}^{2}\right)$ & \\
\hline$\overline{\text { Clackamas (A) }}$ & 0.25 & 75 & 300 & $W F_{B}=\left(A L s t_{B}\right)=\frac{200}{-}=0.40$ \\
\hline Marion (B) & 0.40 & 200 & 500 & $\mathrm{ALs}_{\mathrm{B}}$ \\
\hline
\end{tabular}

Step 3 Calculate the land-cover weighted estimates (of atrazine use on crops) for the source zones that intersect the target zone-(0st).

\begin{tabular}{|c|c|c|c|c|c|c|}
\hline \multicolumn{4}{|c|}{$\begin{array}{l}\text { Weighted atrazine use (0st) , weighting factors } \\
\text { (WF) and atrazine use on crops, countywide (Qs) }\end{array}$} & \multicolumn{2}{|c|}{$\begin{array}{c}\text { Atrazine use }(\mathrm{kg}) \text { on crops, } \\
\text { countywide (Os) }\end{array}$} & \multirow{4}{*}{$\begin{array}{l}0 \mathrm{ust}_{A}=\left(W F_{A} * 0 s_{A}\right) \\
=0.025 * 1,200(\mathrm{~kg})=300 \mathrm{~kg} \\
0 \mathrm{st}_{B}=\left(W F_{B} * 0 s_{B}\right) \\
=0.040 * 8,000(\mathrm{~kg})=3,200 \mathrm{~kg}\end{array}$} \\
\hline County & Ost $(\mathrm{kg})$ & WF & Os (kg) & County & Os (kg) & \\
\hline$\overline{\text { Clackamas (A) }}$ & 300 & 0.25 & 1,200 & $\overline{\text { Clackamas }(\mathrm{A})}$ & 1,200 & \\
\hline Marion (B) & 3,200 & 0.40 & 8,000 & Marion (B) & 8,000 & \\
\hline
\end{tabular}

Step 4 Sum the weighted estimates to calculate the estimated amount (of atrazine use on crops) for the target zone (Pudding River basin)—(OLt).

\begin{tabular}{|c|c|}
\hline $\begin{array}{l}\text { Estimated amount of atrazine use on } \\
\text { crops for the Pudding River basin (QLt) }\end{array}$ & $\begin{array}{c}\mathrm{QLt}=0 \mathrm{st}_{\mathrm{A}}+\mathrm{Qst}_{\mathrm{B}}=300+3,200=3,500 \mathrm{~kg} \\
\text { or }\end{array}$ \\
\hline QLt (kg) & ALst $_{B} * 0 c_{0}$ \\
\hline $3,500 \mathrm{~kg}$ & $U L \mathrm{ALs} A$ \\
\hline
\end{tabular}


Then, step 2 (fig. 9, step 2) calculates the weighting factors for the selected land-cover classification for the source zones (counties) that intersect the target zone (Pudding River basin). In this example, the (cropland-weighted) weighting factor for a county is equal to the area of cultivated crops in the county and basin divided by the countywide area of cultivated crops. Accordingly, the weighting factors for counties A and B are 75 divided by 300, or 0.25 , and 200 divided by 500, or 0.4 , respectively.

In figure 9, step 3, the weighted attribute (of atrazine use) values for the source zones that intersect the target zone (Pudding River basin) are calculated. The weighted atrazine use value for a county is calculated by multiplying the county's weighting factor by the county's atrazine use value. The example shows $1,200 \mathrm{~kg}$ of atrazine is applied in county A and $8,000 \mathrm{~kg}$ in county $\mathrm{B}$; thus, the weighted atrazine use for counties A and B are 0.25 multiplied by $1,200 \mathrm{~kg}$, or $300 \mathrm{~kg}$, and 0.4 multiplied by $8,000 \mathrm{~kg}$, or $3,200 \mathrm{~kg}$, respectively.

The final step (fig. 9, step 4) is to sum the weighted attribute values determined in the previous step to calculate the quantitative estimate of the attribute (atrazine use) for the target zone (Pudding River basin). The $300 \mathrm{~kg}$ estimated for county A and 3,200 kg of atrazine use estimated for county B are added, which results in an estimate of 3,500 kg of atrazine used in the Pudding River basin. If area-weighted areal interpolation was used in this example rather than land-cover weighted areal interpolation, the atrazine use estimate would have been 3,120 kg:

$$
\begin{gathered}
(0.6 \times 1,200 \mathrm{~kg} \text { atrazine })+(0.3 \times 8,000 \mathrm{~kg} \text { atrazine }) \\
=720+2,400=3,120 \mathrm{~kg},
\end{gathered}
$$

or about 11 percent lower than the $(3,500 \mathrm{~kg})$ estimate derived from using land-cover weighted interpolation.

For the most part, applying land-cover-weighted areal interpolation over area-weighted areal interpolation improves estimates of total quantities, but in some cases, the results are identical. In the example above, if the land cover for the two counties, Clackamas and Marion, was entirely cropland, the area-weighted and land-cover-weighted weighting factors would have been the same, thereby producing the same atrazine-use estimates. The same results would be observed if the cropland in both counties comprised multiple polygons, but all fell entirely within the basin. Therefore, the spatial distribution of the selected land classification(s) within the (partially intersecting) source zone in relation to the target zone determines the degree of potential accuracy improvement with the addition of mapped land cover.

Note that if the intention was to acquire atrazine-use intensity over a drainage basin, there are multiple options. One approach would be to divide the pesticide use estimate derived from land-cover-weighted areal interpolation (as illustrated in $\underline{\text { fig. } 9}$ ) by the area of the drainage basin. Two alternate approaches would require the preexistence of a pesticide-use-on-cropland raster that was developed by weighting the (county-based) pesticide use on crops over areas of mapped agricultural land (Nakagaki, 2007a,b). These pesticide use rasters could be used with simple areal overlay to acquire pesticide-use intensity by (1) obtaining the sum of the pesticide-use grid cell values within the basin, then dividing the sum by the basin area, or by (2) obtaining the mean of the pesticide-use grid cell values within the basin. One consideration for deciding whether simple areal overlay would be sufficient is to determine if the resolution of the pesticide-use raster is suitable for the size of the study areas. The size of the study areas alone however, is not a completely reliable indicator for determining the appropriate grid cell resolution (Nakagaki and Wolock, 2005). Although outliers are not common, exceptions do occur. The most suitable method is often decided from the level of precision desired and an acceptable margin of error for the particular application.

\section{Limitations and Related Adjustments}

The characteristics compiled for NAWQA sites and associated study areas are subject to a number of limitations that can be grouped as either data-driven or method-driven. Factors that contribute to potential error from the input data include the accuracy of the sampling site locations, study area boundaries, and the inherent quality of the GIS thematic dataset. In regard to the methods, area-weighted interpolation gives rise to potential error based on the assumption of uniform distribution or density of the attribute; additional error is introduced with land-cover weighted interpolation if the mapped land cover and data table of the attributes by source zones have temporal or other differences that stem from the integration of multiple data sources.

Clearly, the likelihood for erroneous site characteristics is high with the use of inaccurate geographic coordinates for the sampling sites. Such errors generally are more pronounced with discrete data than continuous data. This is due to the nature of continuous data compared to the nature of discrete data: the neighboring cells of continuous data are likely to have either the same, or a slightly higher or lower quantitative value than the grid cell intersecting the station, whereas the neighboring cells of discrete data have a higher likelihood of having a different classification. The difference in value of continuous data typically has much less effect on data analyses. The probability for error is also reduced for sampling stations intersected with either discrete or continuous data with larger grid cells. An incorrect site location, however, can jeopardize not only site characteristics but also well buffer and drainage basin characteristics because these boundaries are developed from the location of the sampling site.

Similarly, inaccurate study-area characteristics are likely to result from the use of inaccurate study-area boundaries. There are different degrees of inaccuracy; for example, a drainage basin boundary derived from topographic and hydrological data at 1:100,000-scale resolution, rather than at the 1:24,000-scale, is insignificant compared to a drainage basin boundary that unintentionally included a noncontributing 
sub-basin that only contributes to the drainage area during major storms. The latter would have a greater effect on basin characteristics because, for instance, the difference in area could alter the percentages of land cover composition enough to alter the basin's major land classification, whereas improving boundaries with higher resolution source data might change only a fraction of the land-cover percentage for the basin.

Additionally, inaccuracies in the GIS thematic dataset will adversely affect the reliability of site and study-area characteristics. Even though the NAWQA program utilized what was believed to be the best quality and most consistent national scale data available, all thematic datasets, in general, have uncertainty associated with them. Furthermore, in many cases the extent of uncertainty is unknown. Whether or not errors introduced are significant depends on the application. For example, if a researcher wishes to know only if land cover in a basin is "green vegetation" or "not green vegetation," then a miscoding in the land cover dataset of "deciduous forest" instead of "orchards/vineyards" is not a problem. However, if the researcher wants an estimate of pesticides applied to orchards and vineyards in the basin, then a miscoding of "deciduous forest” instead of "orchards/vineyards” would be a concern because the error could result in misrepresented agricultural pesticide use for the study area.

Potential errors of study-area characteristics can also be introduced from the methods, such as the assumption of homogeneous distribution of an attribute across source zones with area-weighted interpolation. (Note: this limitation pertains only to partially intersecting source zones within a target zone and not to the source zones entirely within the target zone.) In other words, the reliability of target zone estimates acquired from area-weighted areal interpolation depends on the degree of heterogeneity across the source zones that partially intersect the target zone: the lesser degree of heterogeneity, the lesser likelihood of error.

Errors associated with area-weighted areal interpolation can be minimized by applying the smallest units of source zones possible, such as census blocks in place of counties or census block groups. The census block is the smallest geographic entity for which the U.S. Census Bureau collects; in 1990, there were approximately 7 million census blocks in the conterminous United States compared to about 230,600 census block groups (Hitt, 1994). The constraints to using smaller source zones, however, include the absence of, or difficulty in attaining, readily available mapped and refined source zones, as well as computer-related issues, such as GIS software limitations, additional costs to acquire high performance processors, and large amounts of data storage.

Although land-cover-weighted areal interpolation is a vast improvement over area-weighted interpolation in general, a typical limitation is disagreement in the area of the land categories from mapped land cover (such as area of cropland) compared to tabulated statistics (such as area of cropland on which a pesticide is applied). Unsurprisingly, disagreement arises from the use of multiple data sources because data-collection methods differ and criteria for classifying land differ. The problem is heightened for areas where the mapped land cover is completely missing a land-cover type, whereas the tabulated data indicate otherwise. For example, a drainage basin is located within a county, and the county shows some atrazine use on row crops (say 1,000 acres of cropland), but according to the mapped land cover, there is no cropland in this county. By employing land-cover-weighted interpolation under these conditions, the atrazine use for this county will be completely disregarded and therefore "lost." One approach to avoiding the loss of data (amount of atrazine use, in this case) is to apply area-weighted areal interpolation for these partially intersecting counties in place of landcover weighted interpolation by assuming a homogeneous atrazine-use intensity throughout the county. Unless the entire county consists of agricultural land, however, this approach would more than likely misrepresent the true distribution of agricultural land and, subsequently, misrepresent the allocation of pesticide use.

The process of integrating geographic data compiled from different time spans is an ongoing challenge associated with characteristics calculated from land-cover-weighted areal interpolation. Seamless mapped land cover for the conterminous United States is available for less frequent intervals than statistics by source zone; consequently, national land cover data that correlate closest to the date of the source-zone data are typically used. NAWQA has extensively applied land-cover-weighted areal interpolation by integrating tabulated county data and mapped land cover that match best temporally, but do not coincide completely. Examples include, but are not limited to, (1) county-based estimates of annual agricultural atrazine use from 1998 through 2007 (Thelin, 2010) apportioned on mapped agricultural land from the NLCD 2001 (U.S. Geological Survey, 2007; Homer and others, 2007) and from the NLCD 2006 (Fry and others, 2011; U.S. Geological Survey, 2011) ; (2) county-based areas of agricultural management practices from the 1992 National Resource Inventory (U.S. Department of Agriculture, 1995) and the 1997 Natural Resource Inventory (U.S. Department of Agriculture, 2000), compiled at the county level and distributed on mapped agricultural land (Michael E. Wieczorek, U.S. Geological Survey, written commun., 2004) from the National Land Cover Data 1992 (U.S. Geological Survey, 1999; Vogelmann and others, 2001) and, (3) county-based estimates of historical pesticides, such as dieldrin, DDT, and chlordane, applied on crops (Gail P. Thelin, U.S. Geological Survey, written commun., 2004), alllocated on mapped agricultural land from the Land Use and Land Cover (LULC) dataset, which is based on aerial photographs taken in the 1970s to mid-1980s (U.S. Geological Survey, 1990; Price and others, 2007). 
The reliability of site and study-area characterization will increase as new data sources emerge and existing data sources improve in quality and become available in more frequent intervals. Examples include (1) the refinement of drainagebasin boundaries as higher-quality landscape and mapped hydrography become available; (2) the development of annual pesticide-use estimates by county for the conterminous U.S. from 1992 through 2009 (Gail P. Thelin, written commun., 2012), which will replace the county 1992 and 1997 pesticide-use estimates (Thelin, 2005a,b) and the county 2002 pesticide-use estimates (Gail P. Thelin, written commun., 2007); (3) the completion of the Cropland Data Layer for the conterminous United States (U.S. Department of Agriculture, 2010a; Johnson and Mueller, 2010), which could be used in replacement for the land classified as "cultivated crops" in the National Land Cover Datasets; and (4) the replacement of the 1:250,000-scale State Soil Geographic (STATSGO) database, which was designed for regional and national analyses (U.S. Department of Agriculture, 1994), with 1:12,000-scale to 1:63,360-scale Soil Survey Geographic (SSURGO) database, which was designed for soil analyses at a much smaller scale, such as counties (U.S. Department of Agriculture, 2010b).

\section{Summary}

The physical and anthropogenic characteristics that define the environmental settings of NAWQA's sampling sites and study areas are critical variables that support national water-quality assessment. It is essential that the calculation of these characteristics be performed using methods that result in consistency in data development and geoprocessing. This report described the three major methods for site characterization and provided references and online linkages to the national GIS data sources used by NAWQA.

\section{Acknowledgments}

The authors acknowledge and appreciate David M. Wolock, for his technical assistance with the methods described in this report. The authors would also like to express our sincere appreciation to the numerous hydrologists and geographers of the U.S. Geological Survey who spent countless hours preparing the GIS datasets of drainage basin and groundwater study-area boundaries used to characterize the sampled sites and study areas analyzed in the NAWQA program. Finally, a number of national geospatial datasets used for characterization have been developed by our colleagues, namely, Nancy T. Baker, Jo Ann M. Gronberg, Andrew E. LaMotte, Barbara C. Ruddy, Gail P. Thelin, Michael E. Wieczorek, and David M. Wolock.

\section{References Cited}

Bell, R.W., and Williamson, A.K., 2006, Data delivery and mapping over the web-National Water-Quality Assessment Data Warehouse: U.S. Geological Survey Fact Sheet, 2006-3101, 6 p.

Fisher, P.F., and Langford, M., 1996, Modeling sensitivity to accuracy in classified imagery-A study of areal interpolation by dasymetric mapping: Professional Geographer, v. 48, no. 3, p. 299-309.

Fry, J., Xian, G., Jin, S., Dewitz, J., Homer, C., Yang, L., Barnes, C., Herold, N., and Wickman, J., 2011, Completion of the 2006 national land cover database for the conterminous United States, Photogrammetric Engineering \& Remote Sensing, v. 77, no. 9, p. 858-864.

Gilliom, R.J., Alley, W.M., and Gurtz, M.E., 1995, Design of the National Water-Quality Assessment ProgramOccurrence and distribution of water-quality conditions: U.S. Geological Survey Circular 1112, 33 p.

Gilliom, R.J., Hamilton, P.A., and Miller, T.L., 2001, The National Water-Quality Assessment Program-Entering a new decade of investigations: U.S. Geological Survey Fact Sheet 071-01, 6 p., accessed August 21, 2003, at http:// water.usgs.gov/pubs/FS/fs-071-01/pdf/fs07101.pdf.

Gilliom, R.J., Barbash, J.E., Crawford, C.G., Hamilton, P.E., Martin, J.D., Nakagaki, Naomi, Nowell, L.H., Scott, J.C., Stackelberg, P.E., Thelin, G.P., and Wolock, D.M., 2006, The Quality of Our Nation's Waters-Pesticides in the Nation's Streams and Groundwater, 1992-2001: U.S. Geological Survey Circular 1291, 172 p., accessed August 29, 2007, at http://ca.water.usgs.gov/pnsp/pubs/ circ1291/index.html.

Hitt, K.J., 1994, Refining 1970's land-use data with 1990 population data to indicate new residential development: U.S. Geological Survey Water-Resources Investigations Report, 15 p.

Holt, J.B., Lo, C.P., and Hodler, T.W., 2004, Dasymetric estimation of population density and areal interpolation of census data: Cartography and Geographic Information Science, v. 31, no. 2, p. 103-121.

Homer, C., Dewitz, J., Fry, J., Coan, M., Hossain, N., Larson, C., Herold, N., McKerrow, A., VanDriel, J.N., and Wickman, J., 2007, Completion of the 2001 national land cover database for the conterminous United States: Photogrammetric Engineering and Remote Sensing, v. 73, no. 4, p. 337-341. 
Johnson, D.M. and Mueller, R., 2010, The 2009 cropland data layer: Photogrammetric Engineering and Remote Sensing, v. 76, no. 11, p. 1201-1205.

Lanfear, K.J., 1991, 1:2,000,000-scale Digital Line Graph files of streams: U.S. Geological Survey digital vector data, accessed November 15, 2007, at http://water.usgs.gov/ lookup/getspatial?stream.

Nakagaki, Naomi, 2007a, Grids of agricultural pesticide use in the conterminous United States, 1992: U.S. Geological Survey digital raster data, accessed August 29, 2007, at http://water.usgs.gov/lookup/getspatial?agpest92grd.

Nakagaki, Naomi, 2007b, Grids of agricultural pesticide use in the conterminous United States, 1997: U.S. Geological Survey digital raster data, accessed August 29, 2007, at http://water.usgs.gov/lookup/getspatial?agpest97grd.

Nakagaki, Naomi, 2010, Drainage basins used for development of the watershed regressions for pesticides (WARP) model: U.S. Geological digital vector data, accessed June 4, 2010, at http://water.usgs.gov/lookup/ getspatial?warpbas2010.

Nakagaki, Naomi, and Wolock, D.M., 2005, Estimation of agricultural pesticide use in drainage basins using land cover maps and county pesticide data: U.S. Geological Survey Open-File Report, 2005-1188, 46 p., accessed August 29, 2007, at http://pubs.usgs.gov/of/2005/1188/.

National Atlas of the United States, 2005, 2000 County boundaries of the United States: National Atlas of the United States, Reston, Va., U.S. Geological Survey digital vector data, accessed July 19, 2005, at http://nationalatlas. gov/atlasftp.html.

Nolan, B.T., and Hitt, K.J., 2006, Vulnerability of shallow groundwater and drinking-water wells to nitrate in the United States: Environmental Science and Technology, v. 40, no. 24, p. 7834-7840, accessed December 10, 2007, at http://water.usgs.gov/nawqa/nutrients/pubs/est v40 no24/.

Nowell, L.H., Crawford, C.G., Nakagaki, N., Thelin, G.P., and Wolock, D.M., 2006, Regression model for explaining and predicting concentrations of dieldrin in whole fish from United States streams: U.S. Geological Survey Scientific Investigations Report 2006-5020, 30 p., accessed August 29, 2007, at http://pubs.usgs.gov/sir/2006/5020.

Price, C.V., Nakagaki, Naomi, Hitt, K.J., and Clawges, R.M., 2007, Enhanced historical land-use and land-cover data sets of the U.S. Geological Survey: U.S. Geological Survey Data Series 240, accessed August 29, 2007, at http://pubs.usgs. gov/ds/2006/240.
Price, C.V., Nakagaki, Naomi, and Hitt, K. J., 2010, National Water-Quality Assessment (NAWQA) AreaCharacterization Toolbox, Release 1.0, U.S. Geological Survey Open-File Report 2010-1268 [online-only], accessed November 5, 2012, at http://pubs.usgs.gov/ ofr/2010/1268.

Riebel, M., and Agrawal, A., 2007, Areal interpolation of population counts using pre-classified land cover data: Population Research and Policy Review, v. 26, p. 619-33.

Squillace, P.J., and Price, C.V., 1996, Urban land-use study plan for the National Water-Quality Assessment Program: U.S. Geological Survey Open-File Report 96-217, 19 p., accessed November 5, 2012, at http://pubs.usgs.gov/ of/1996/0217/report.pdf.

Stackelberg, P.E., Gilliom, R.J., Wolock, D.M., and Hitt, K.J., 2006, Development and application of a regression equation for estimating the occurrence of atrazine in shallow groundwater beneath agricultural areas of the United States: U.S. Geological Survey Scientific Investigations Report 2005-5287, 27 p., accessed August 29, 2007, at http://pubs. usgs.gov/sir/2005/5287.

Stone, W.W., Gilliom, R.J., and Crawford, C.G., 2008, Watershed Regressions for Pesticides (WARP) for Predicting Annual Maximum and Maximum MovingAverage Concentrations of Atrazine in Streams: U.S. Geological Survey Open-File Report 08-1186, 19 p.

Sun, R.J., Weeks, J.B., and Hayes, F.G., 1997, Bibliography of Regional Aquifer-System Analysis Program of the U.S. Geological Survey, 1978-96: U.S. Geological Survey Water-Resources Investigations Report 97-4074, accessed November 29, 2007, at http://water.usgs.gov/ogw/rasa/html/ introduction.html.

Thelin, G.P., 2005a, 1992 County pesticide use estimates for 200 compounds (ver. 2.0), U.S. Geological Survey digital file, accessed October 27, 2005, at http://water.usgs.gov/ lookup/getspatial?pesticide use92.

Thelin, G.P., 2005b, 1997 County pesticide use estimates for 220 compounds (ver. 2.0), U.S. Geological Survey digital file, accessed October 27, 2005, at http://water.usgs.gov/ lookup/getspatial?pesticide use97.

Thelin, G.P., 2010, Annual county atrazine use estimates for agriculture (ver. 1.1), digital tabular file, accessed September 22, 2010, at http://water.usgs.gov/lookup/ getspatial?sir2010-5034.

U.S. Department of Agriculture, 1994, State soil geographic (STATSGO) database - data use information: Miscellaneous publication no. 1492, (rev. ed.): Fort Worth, Texas, Natural Resources Conservation Service [variously paged]. 


\section{Methods to Characterize Environmental Settings of Stream and Groundwater Sampling Sites}

U.S. Department of Agriculture, 1995, 1992 National Resources Inventory: Natural Resources Conservation Service, Washington, D.C., and Statistical Laboratory, Iowa State University, Ames, Iowa, [CD-ROM].

U.S. Department of Agriculture, 2000 (Reissued 2001), 1997 National Resources Inventory: Natural Resources Conservation Service, Washington, DC, and Statistical Laboratory, Iowa State University, Ames, Iowa, [CD-ROM].

U.S. Department of Agriculture, 2010a, 2009 Cropland data layer: National Agricultural Statistics Service, accessed December 30, 2011, at http://www.nass.usda.gov/research/ Cropland/SARS1a.htm.

U.S. Department of Agriculture, 2010b, Soil Survey Geographic (SSURGO) Database: Soil Survey Staff, Natural Resources Conservation Service, accessed October 18, 2010, at http://soildatamart.nrcs.usda.gov.

U.S. Geological Survey, 1990, Land use and land cover digital data from 1:250,000- and 1:100,000-scale maps: U.S. Geological Survey Data User Guide, no. 4, 25 p.

U.S. Geological Survey, 1999, National land cover data 1992, accessed June 16, 2005, at http://www.mrlc.gov/nlcd92 data.php.
U.S. Geological Survey, 2000, Groundwater atlas of the United States: U.S. Geological Survey Hydrologic Atlas 730, accessed November 29, 2007, at http://capp.water.usgs. gov/gwa/gwa.html.

U.S. Geological Survey, 2003, National elevation dataset (NED), accessed April 2003, currently at http://nationalmap. gov/elevation.html.

U.S. Geological Survey, 2007, National land cover database 2001, accessed May 25, 2007, at http://www.mrlc.gov/ mrlc2k nlcd.asp.

U.S. Geological Survey, 2010, USGS National Water Quality Assessment Data Warehouse, accessed February 25, 2010, at http://water.usgs.gov/nawqa/data.

U.S. Geological Survey, 2011, National land cover database 2006 (NLCD 2006), accessed April 2011, at http://www. mrlc.gov/nlcd06 data.php.

Vogelmann, J.E., Howard, S.M., Yang, L., Larson, C.R., Wylie, B.K., and Van Driel, N., 2001, Completion of the 1990's national land cover data set for the conterminous United States from Landsat Environmental Mapper data and ancillary data sources: Photogrammetric Engineering and Remote Sensing, v. 67, p. 650-662. 


\section{Appendix A. The National GIS Thematic Datasets Used by the National Water-Quality Assessment (NAWQA) Program to Characterize Sampling Sites for Streams and Groundwater}


This page intentionally left blank. 


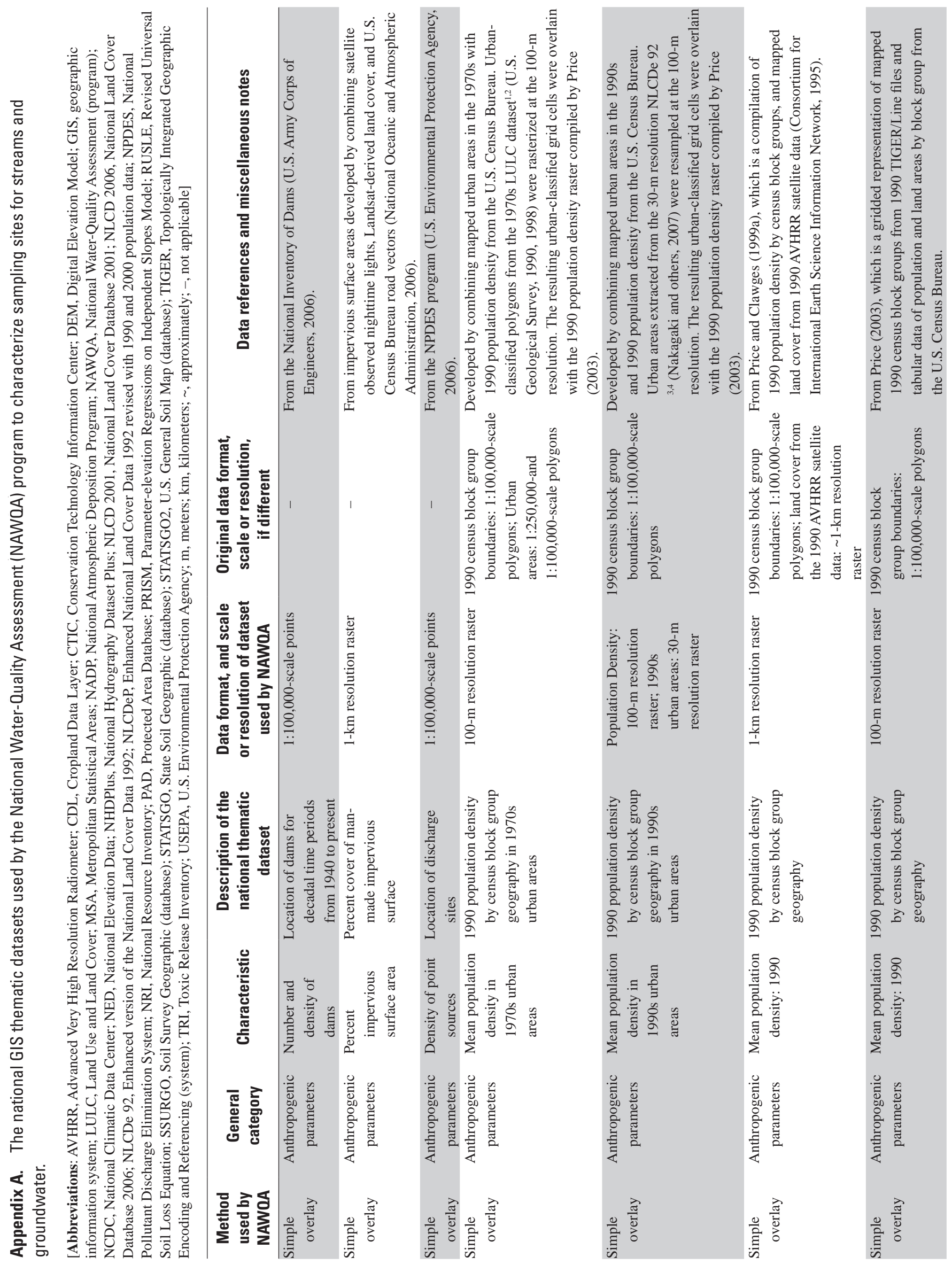




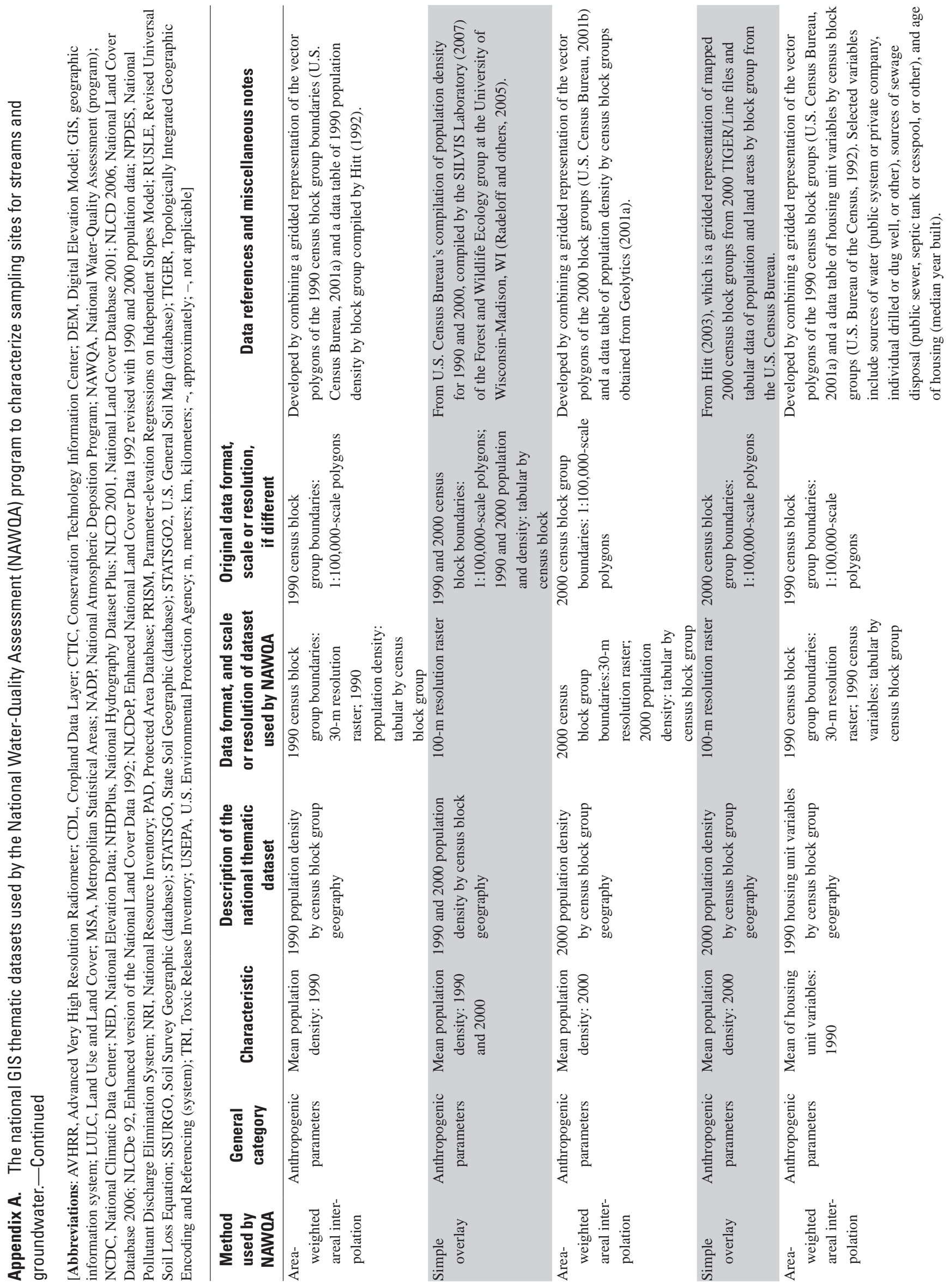



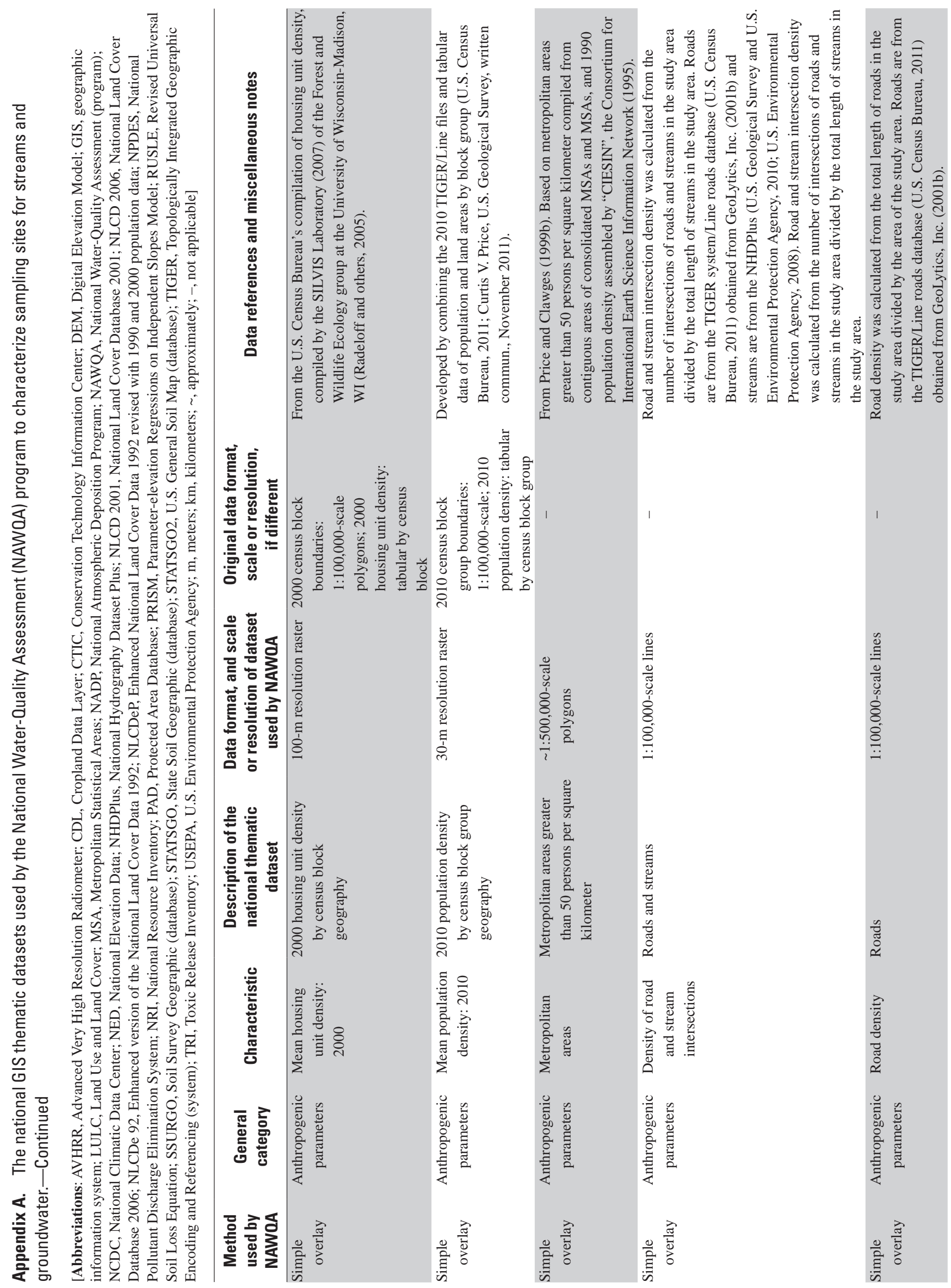


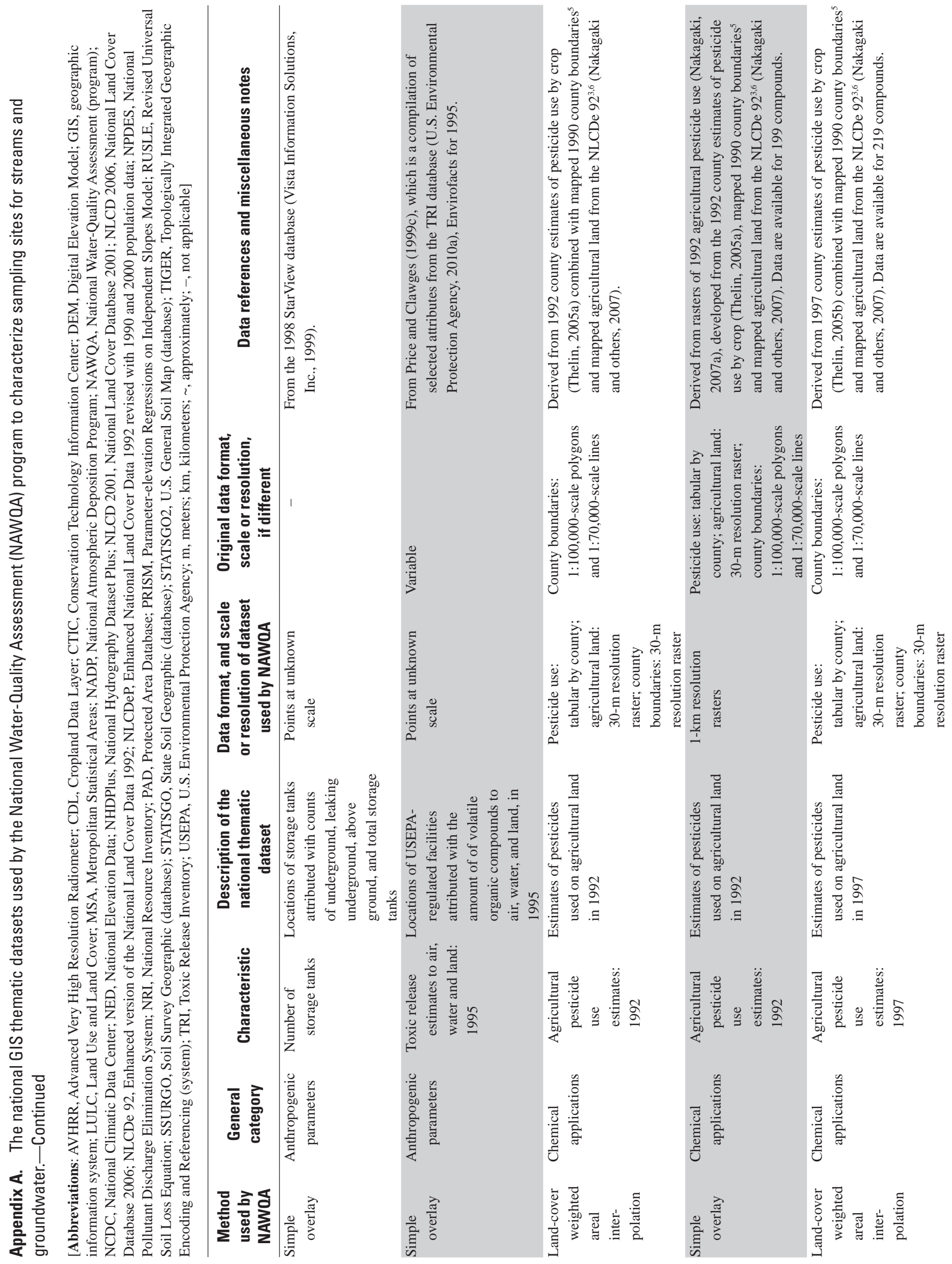



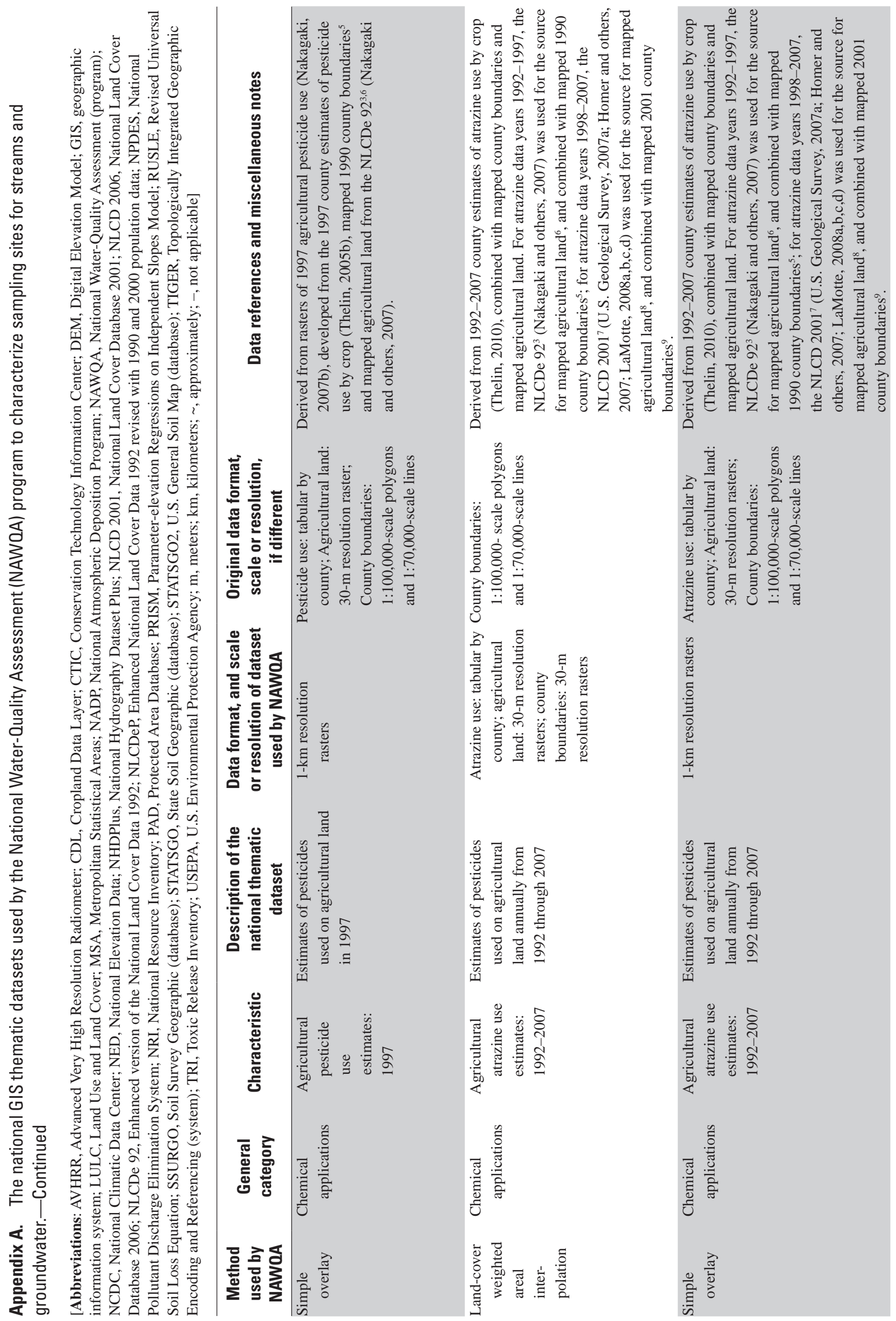


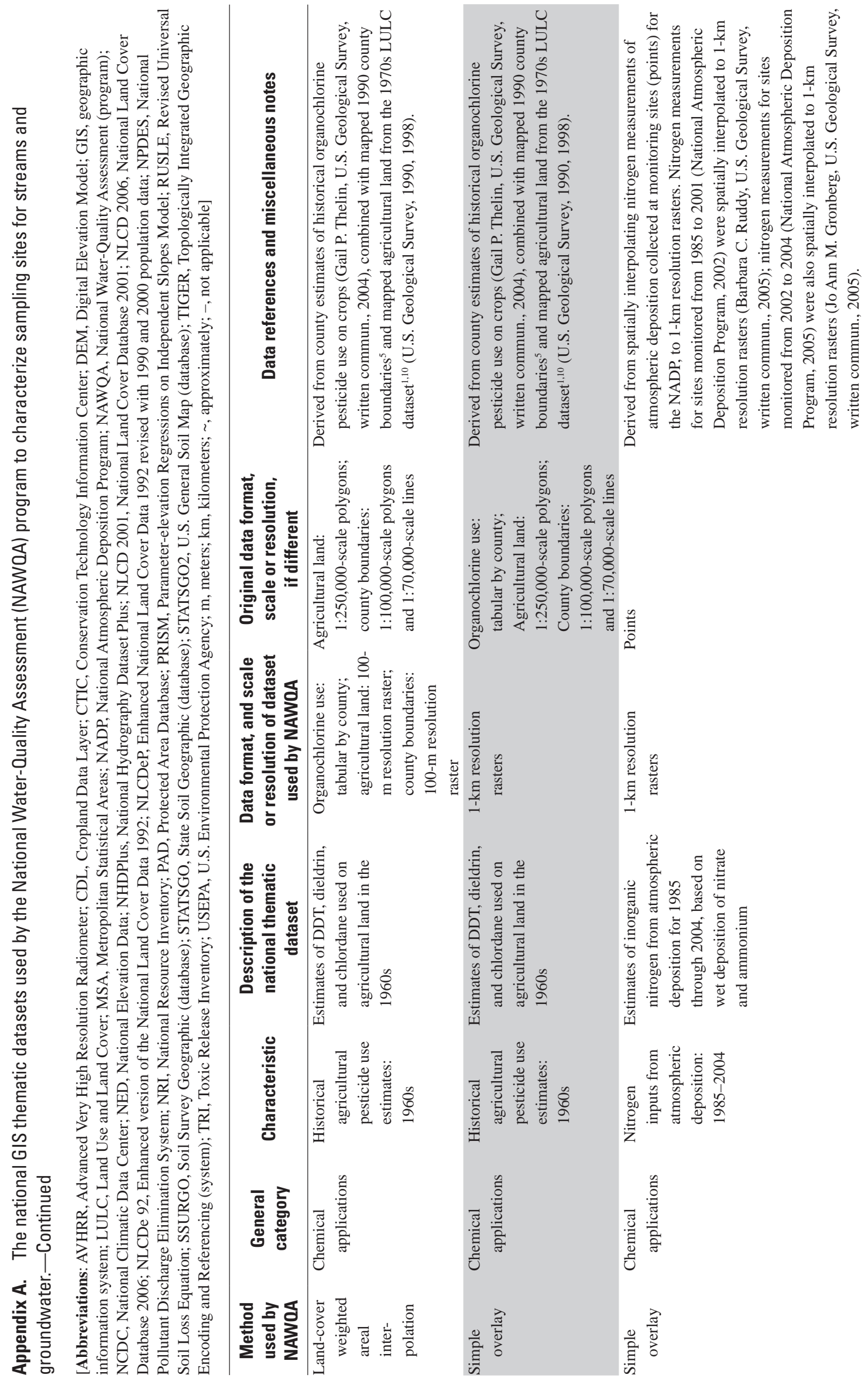



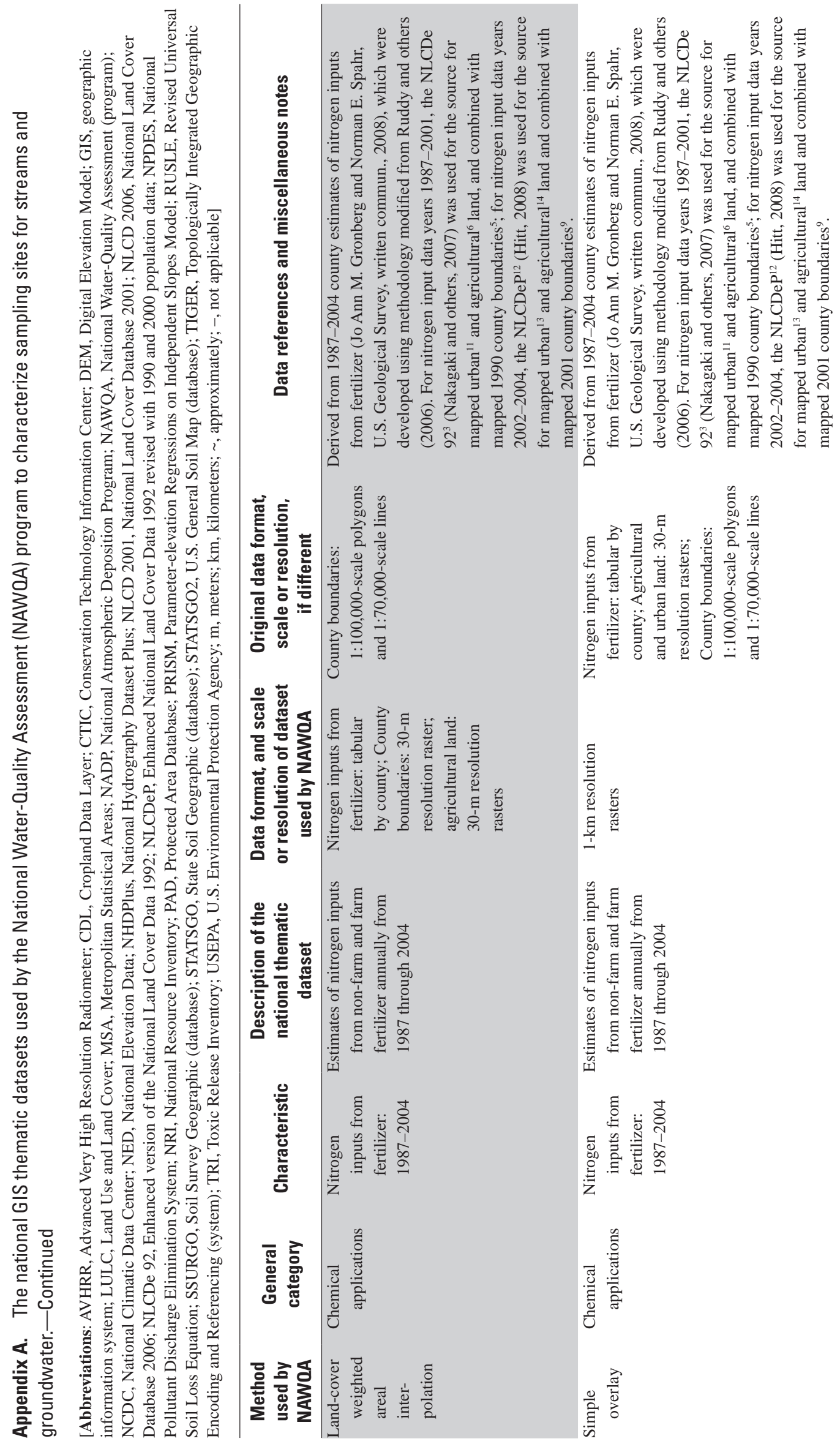


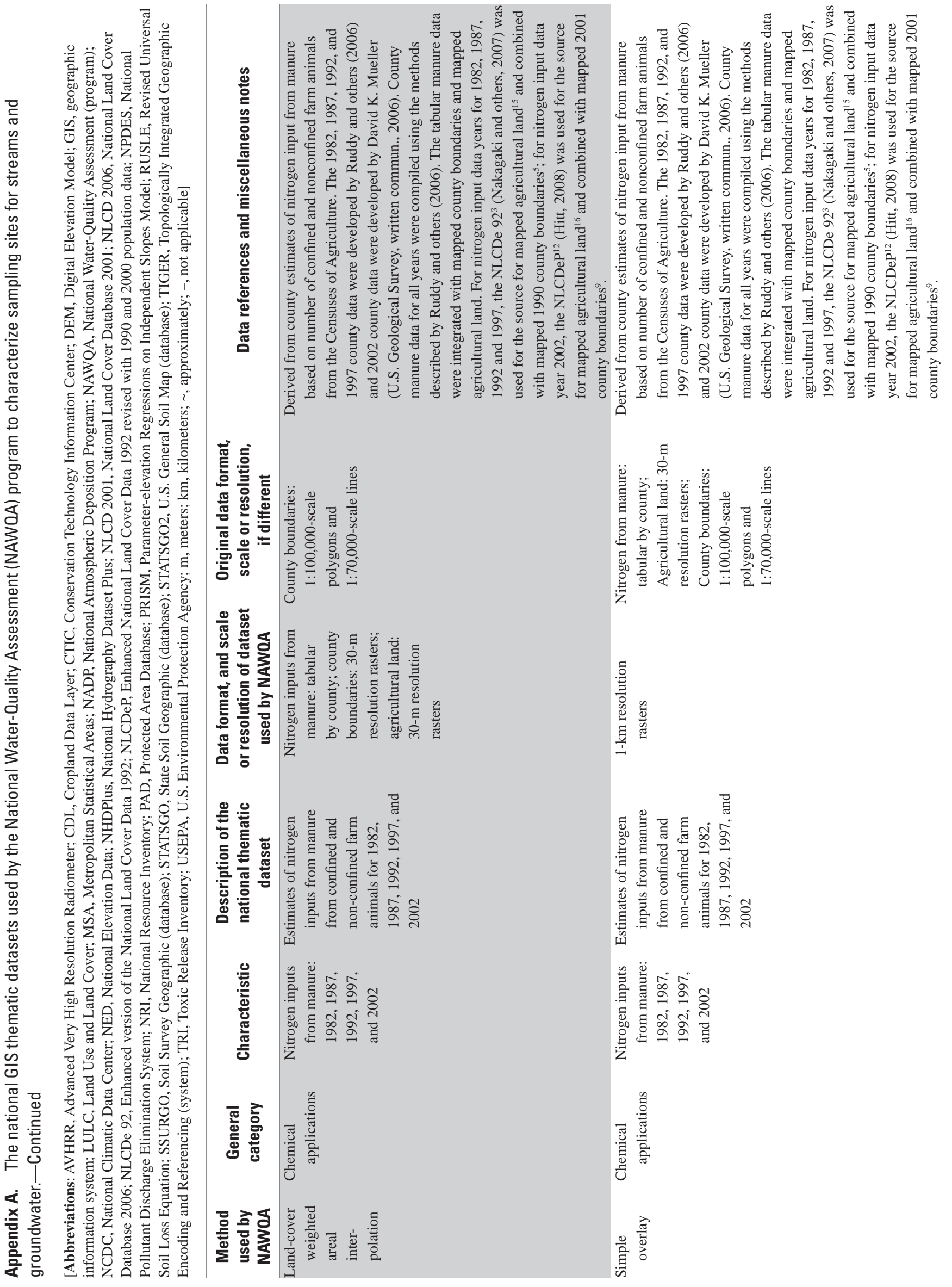



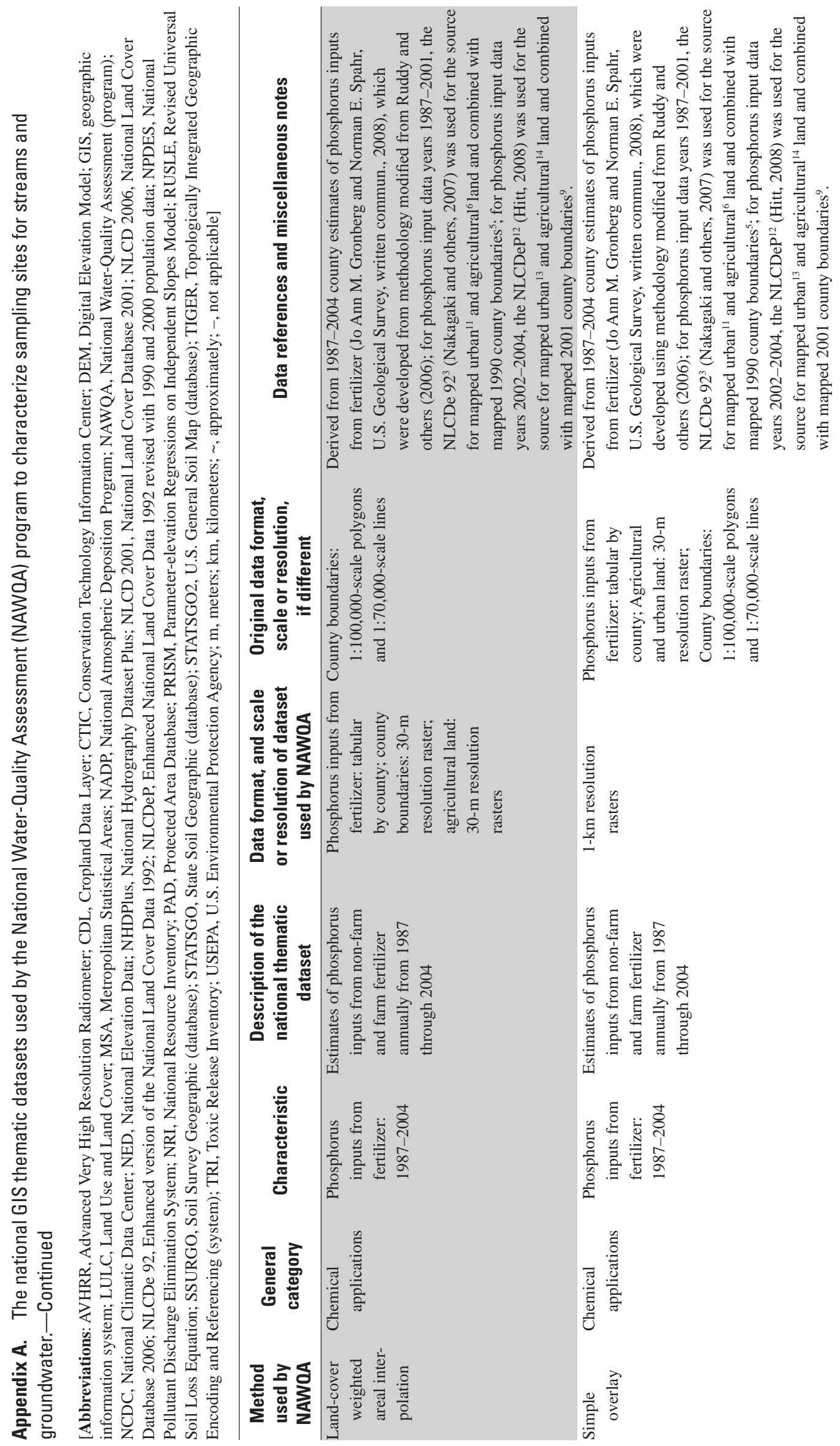


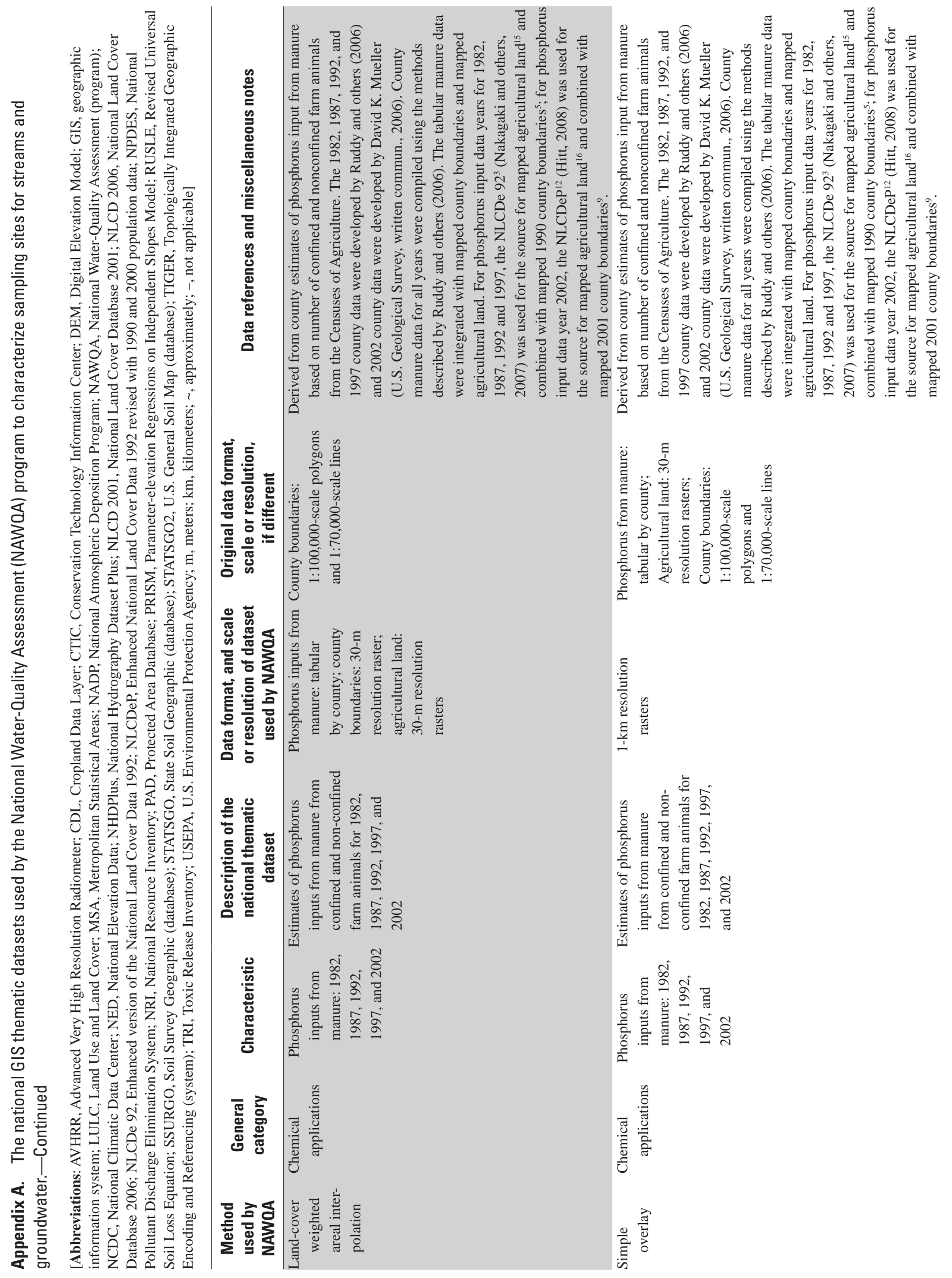




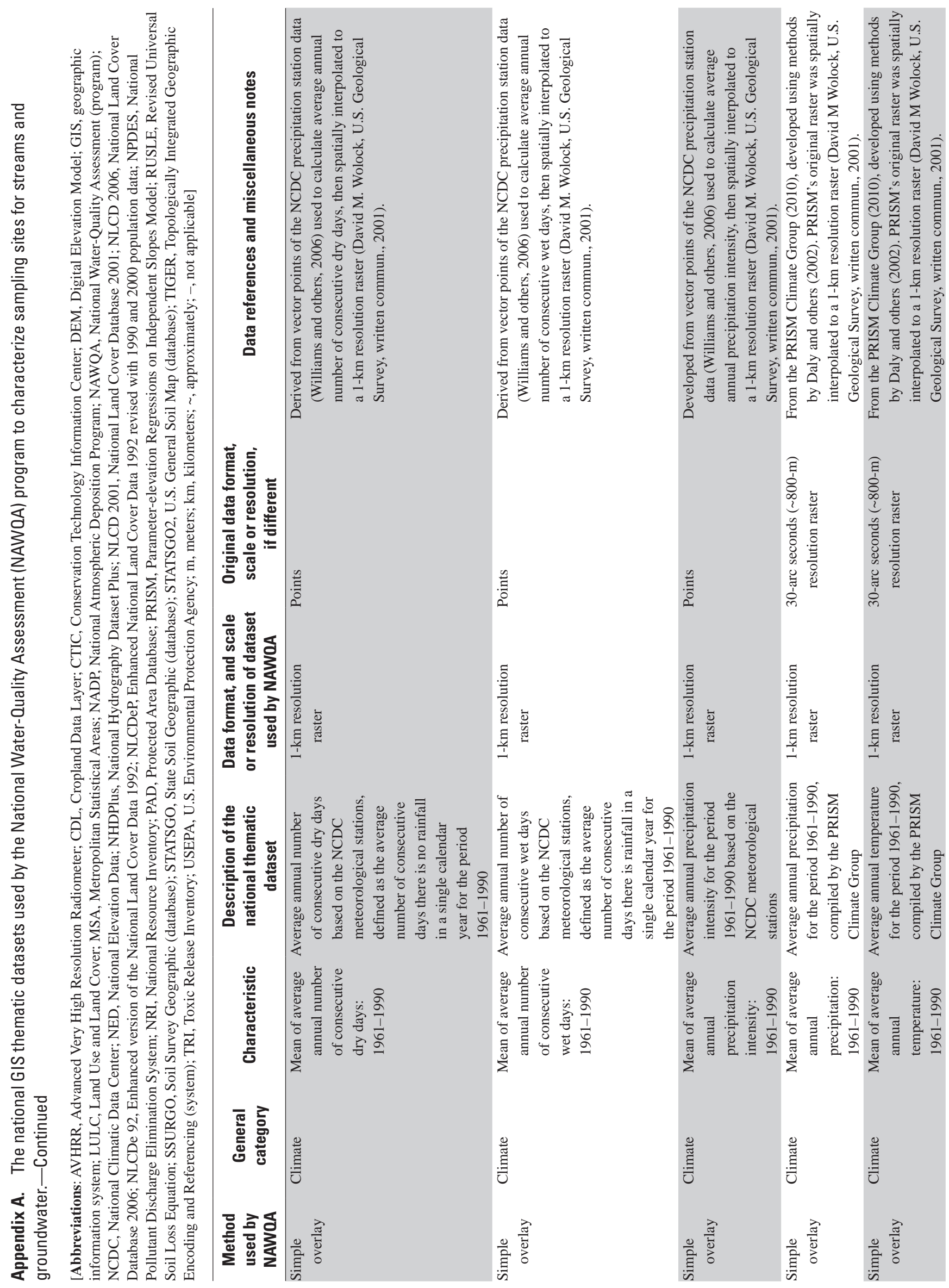




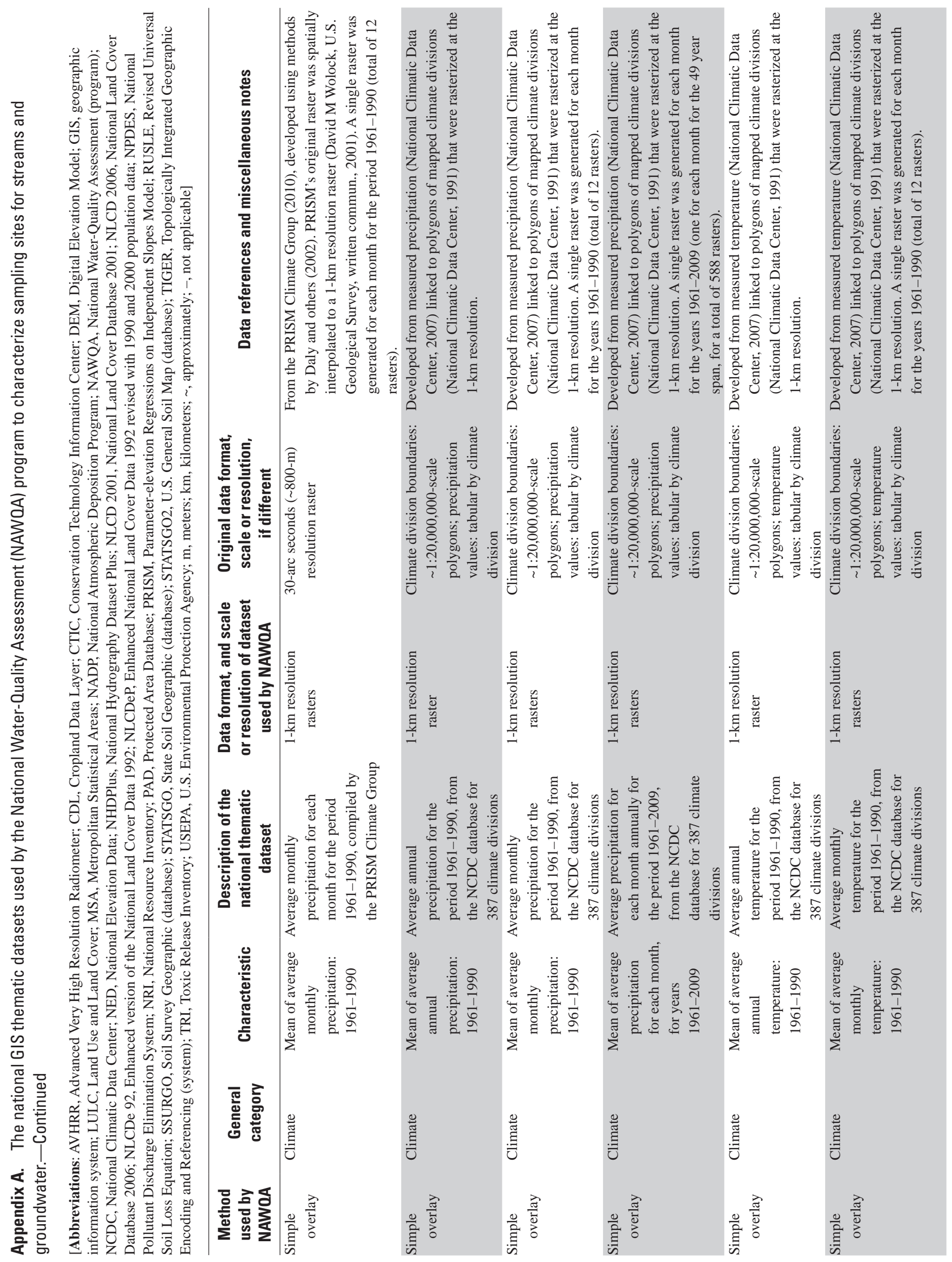



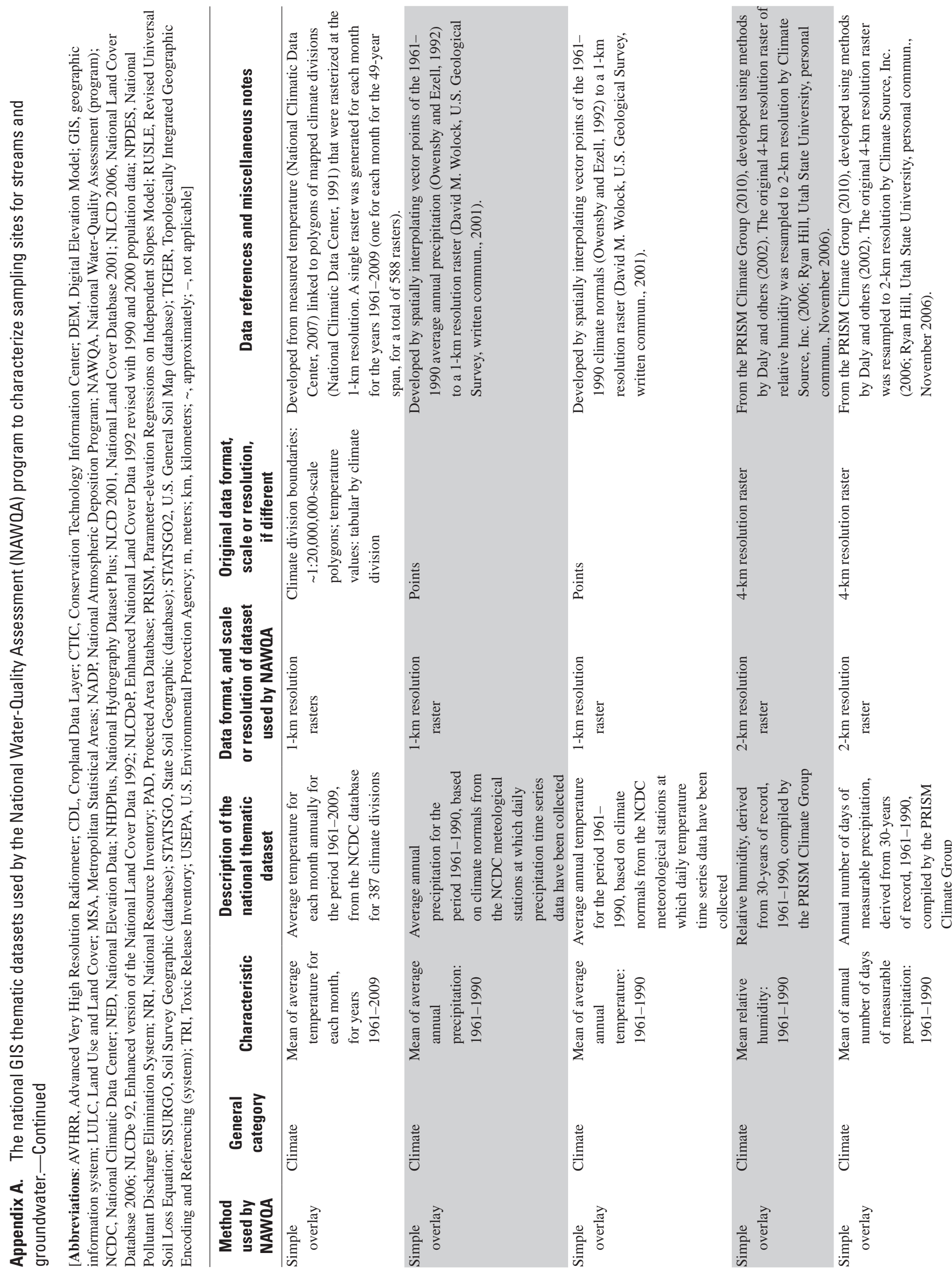


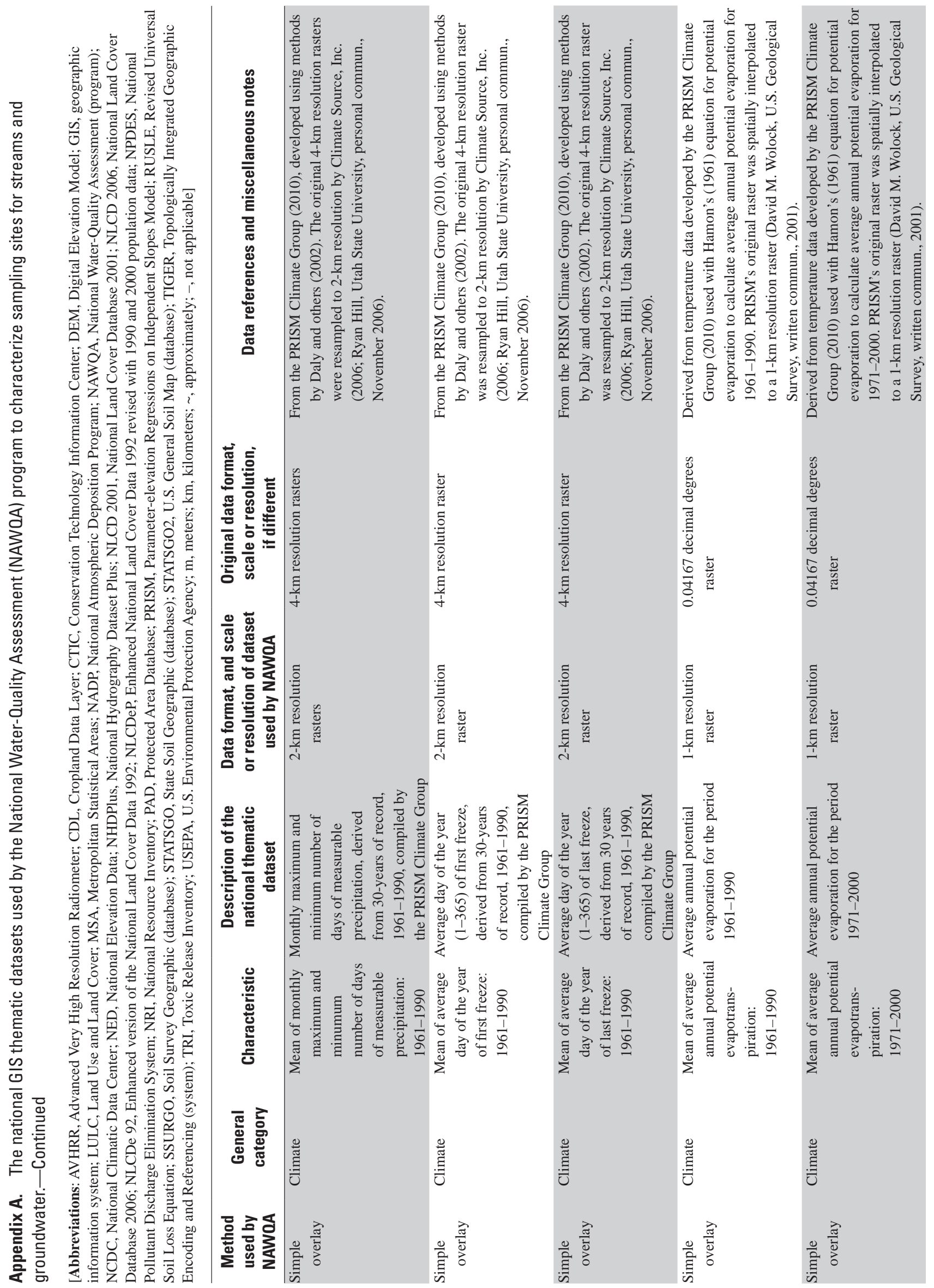




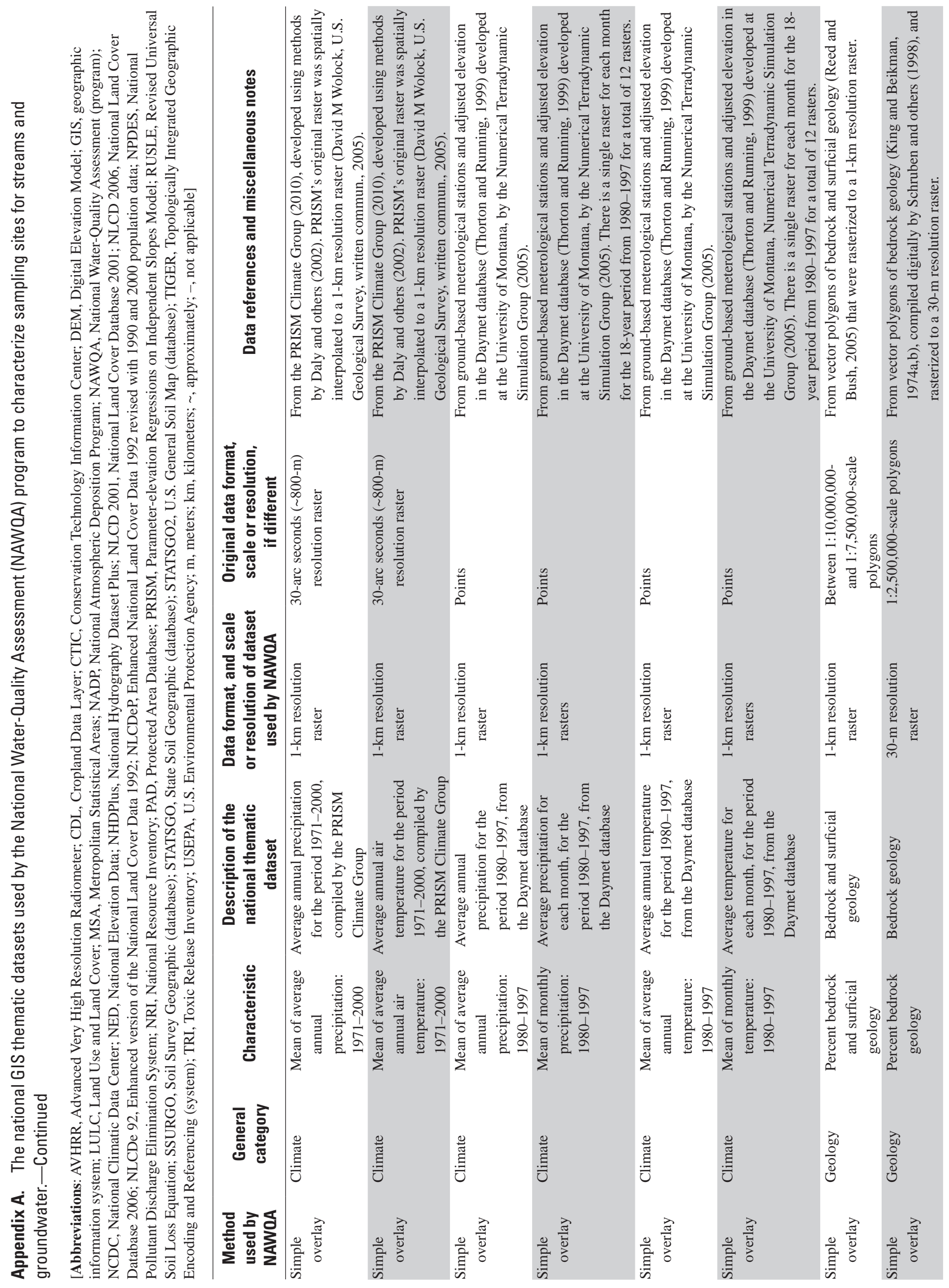




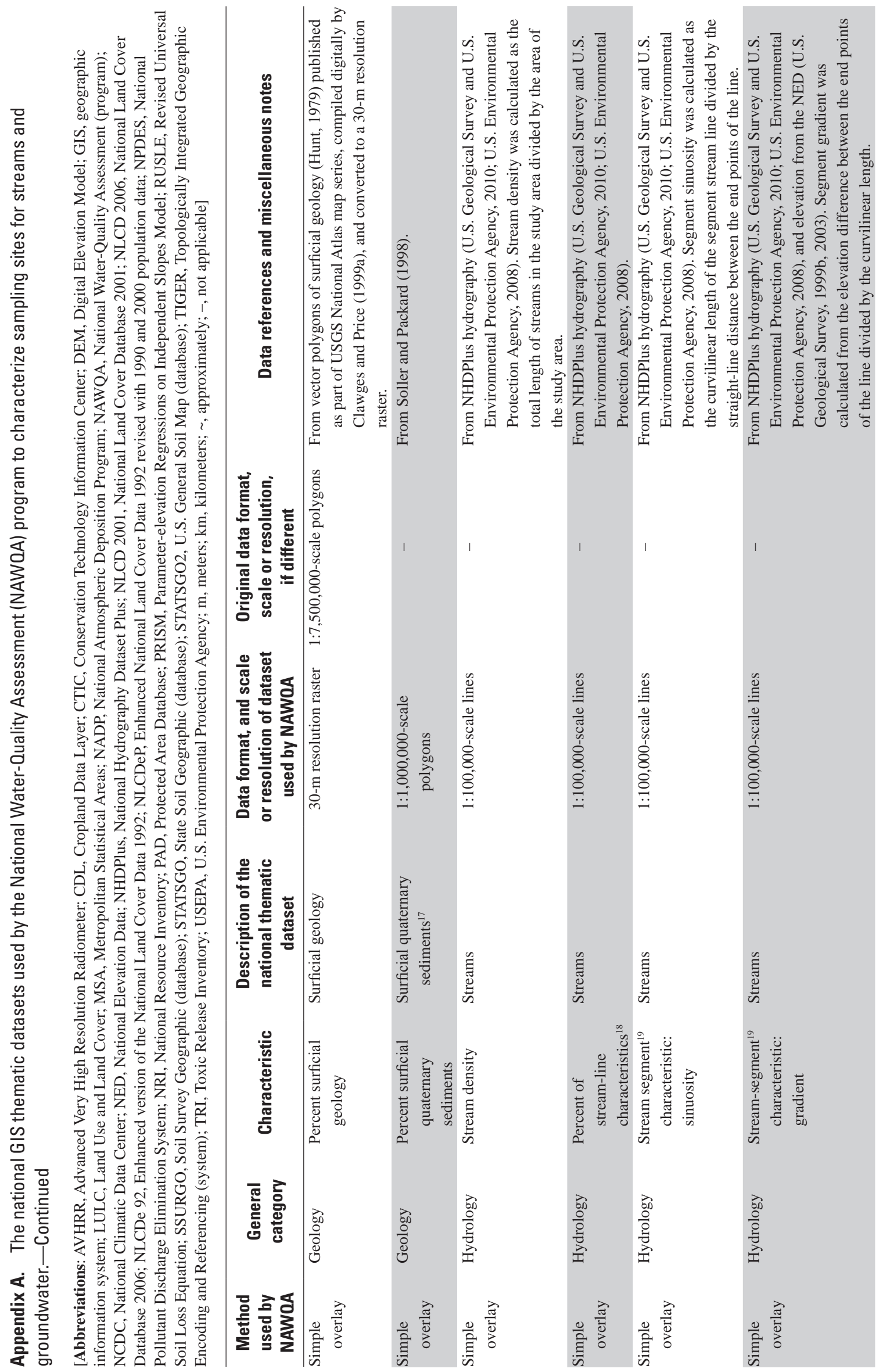




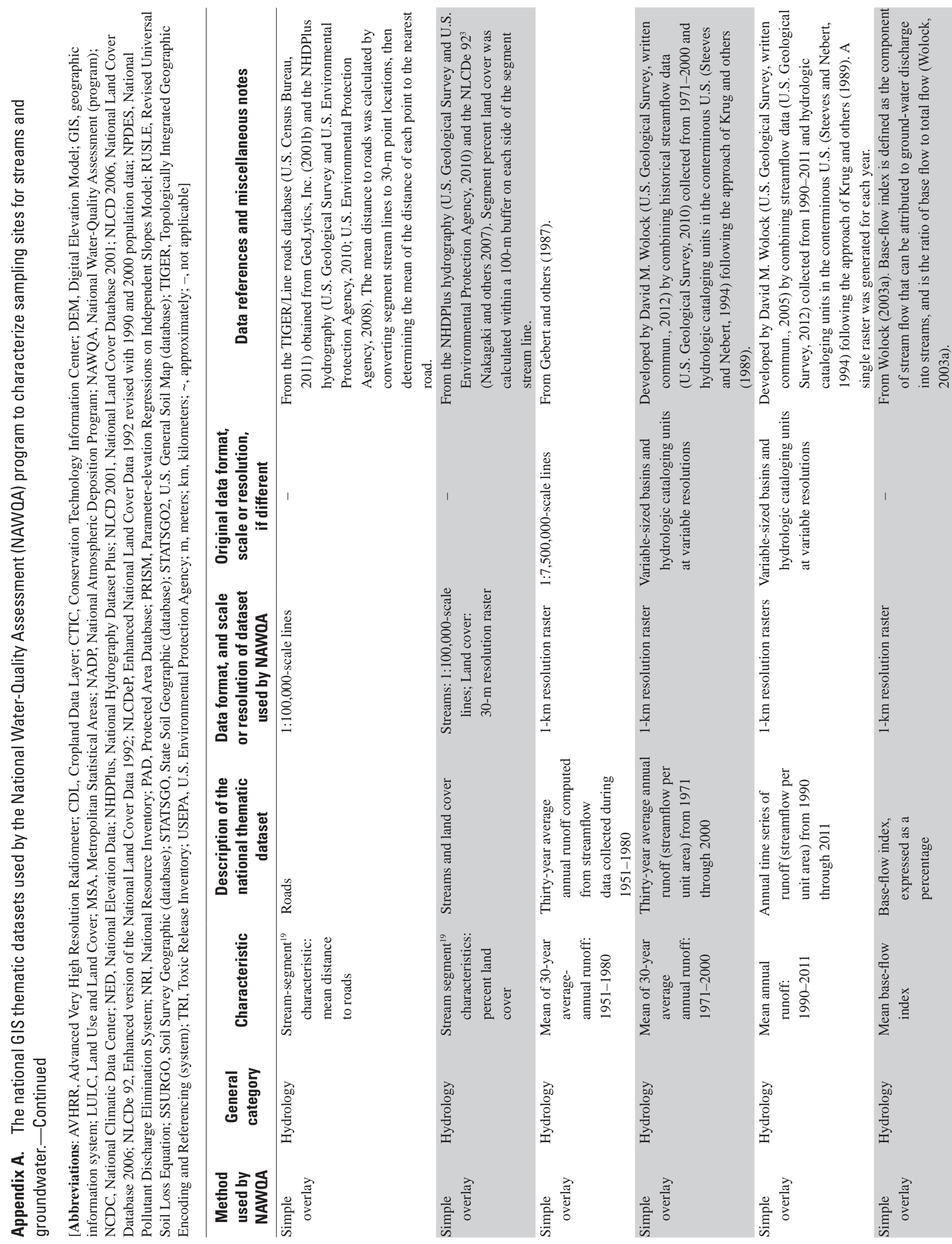




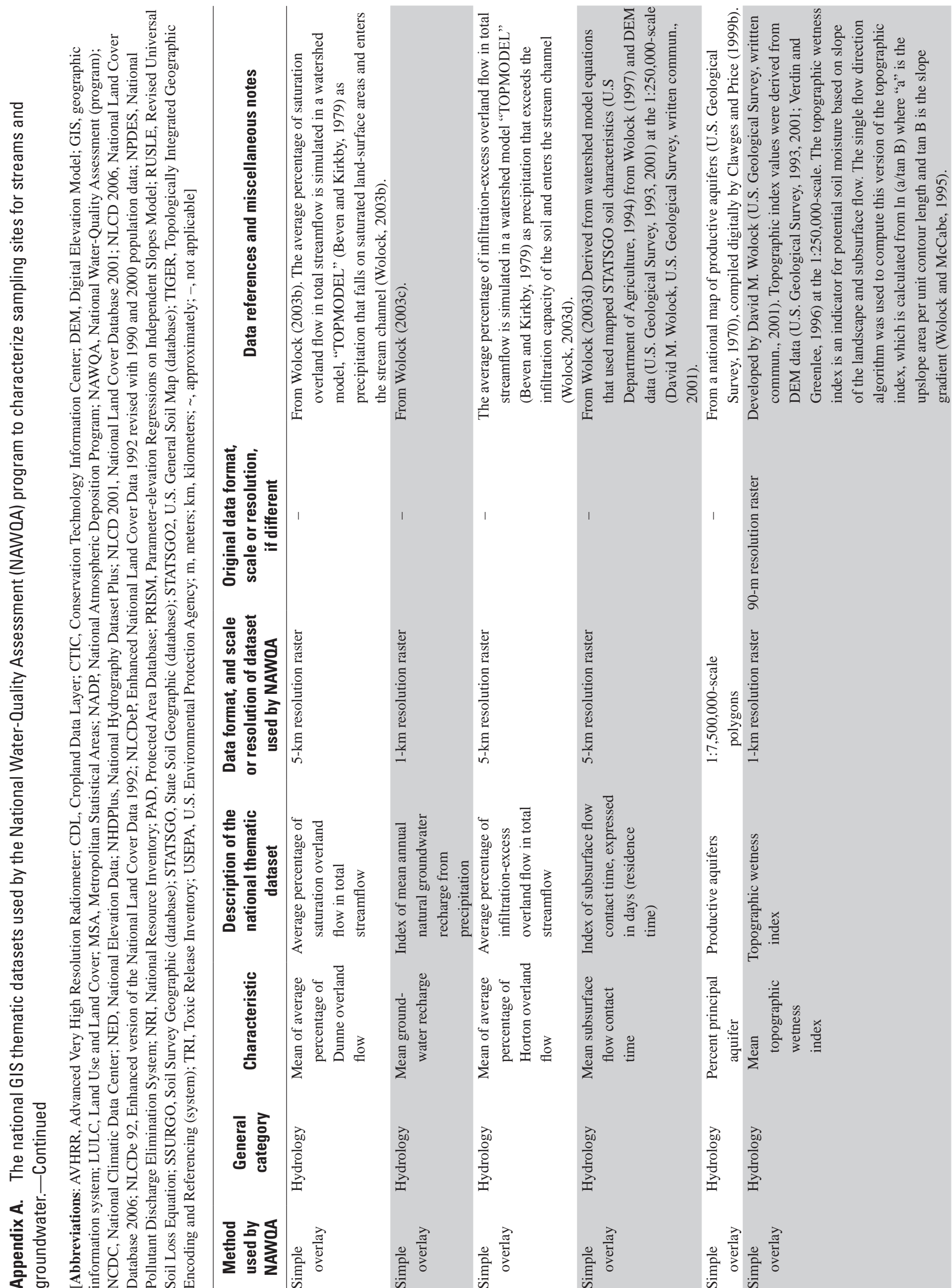



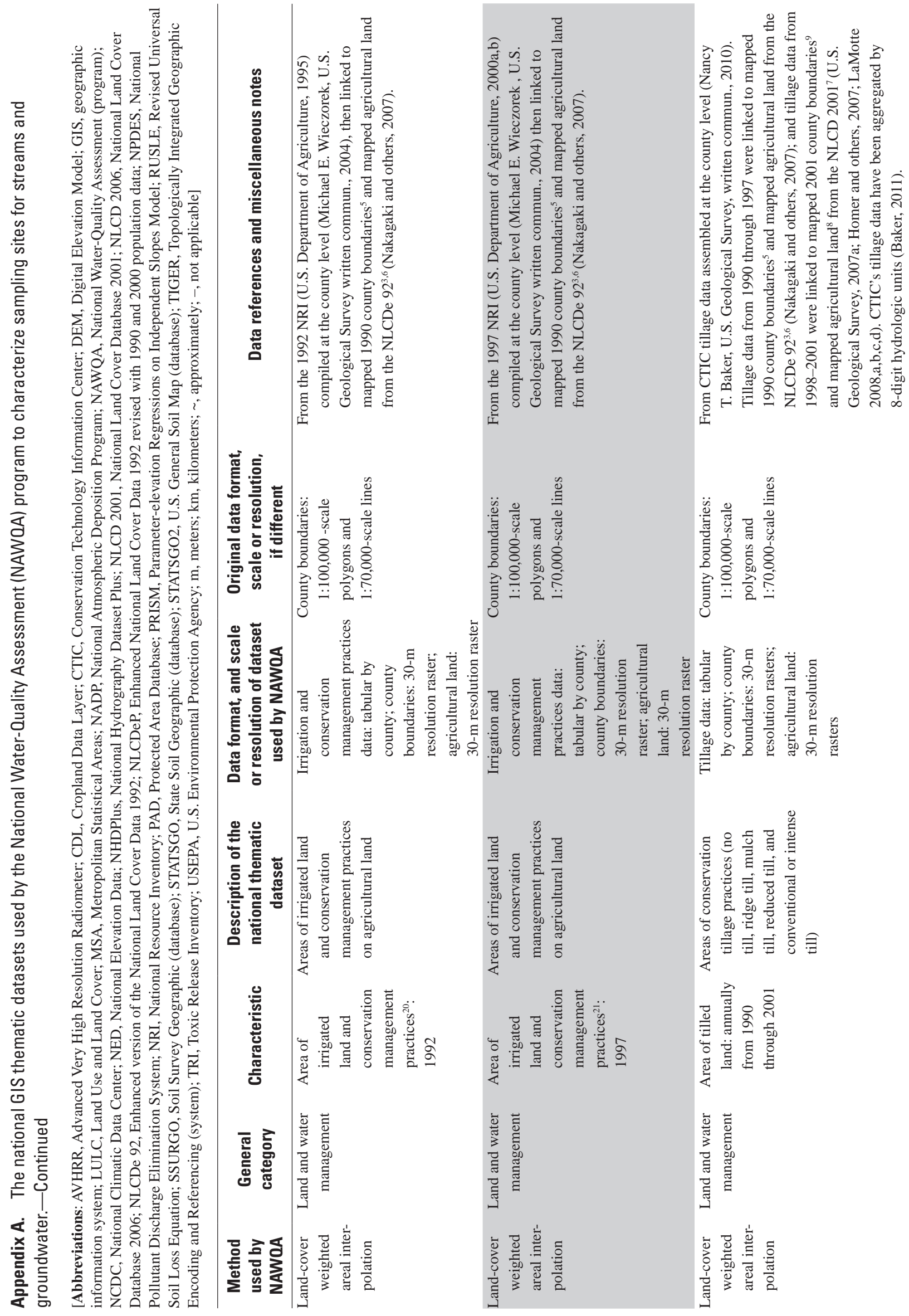


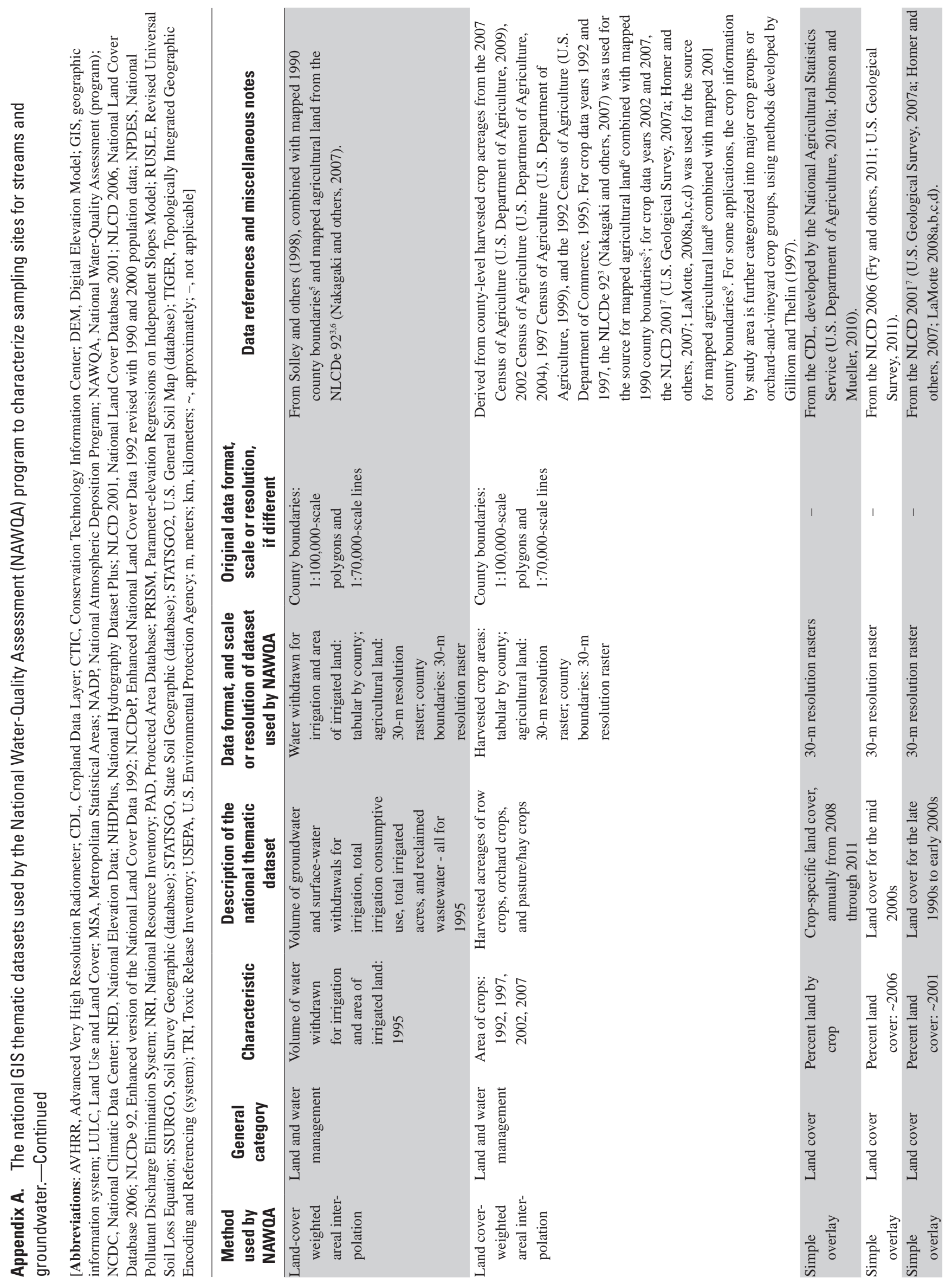




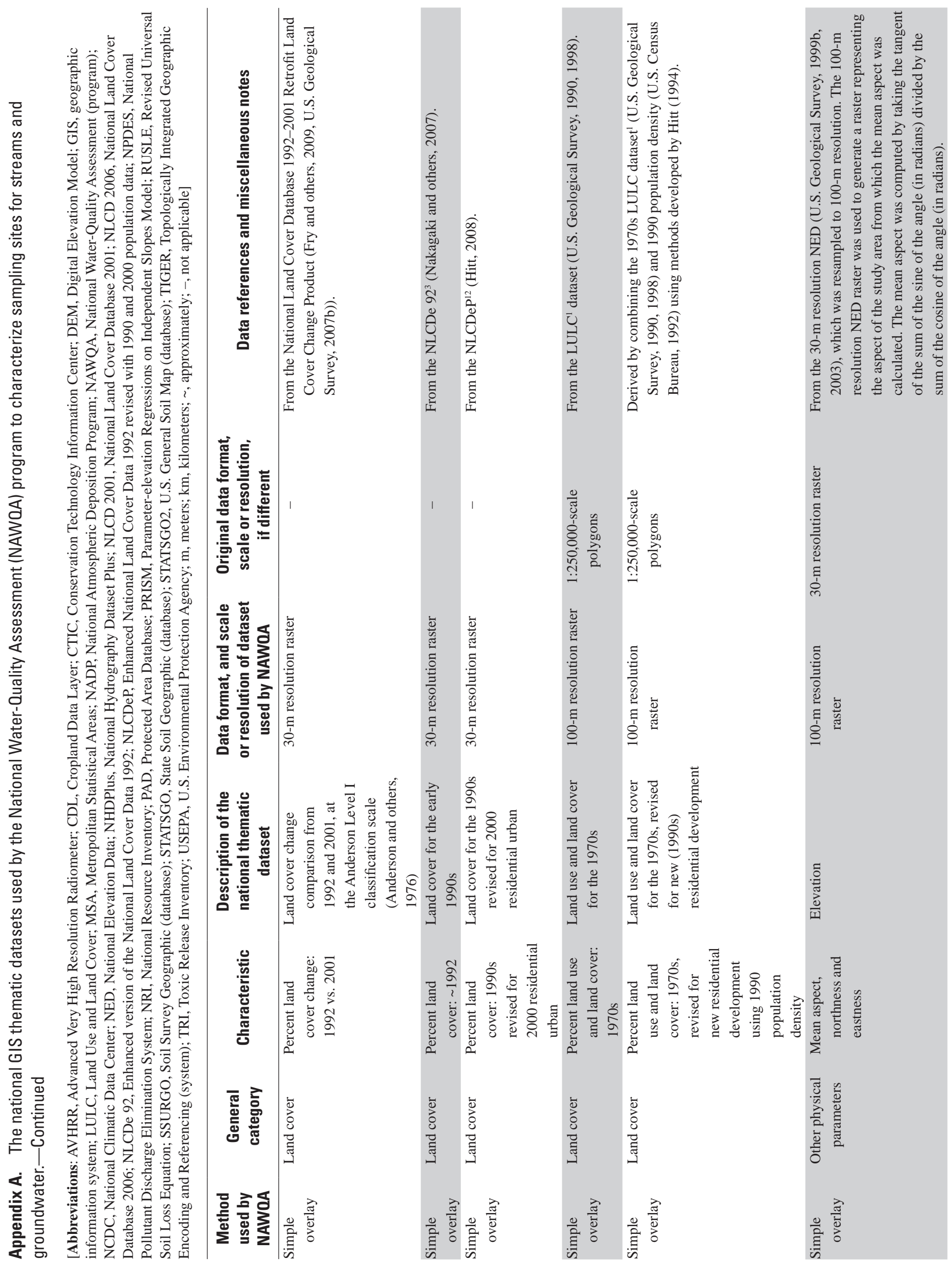




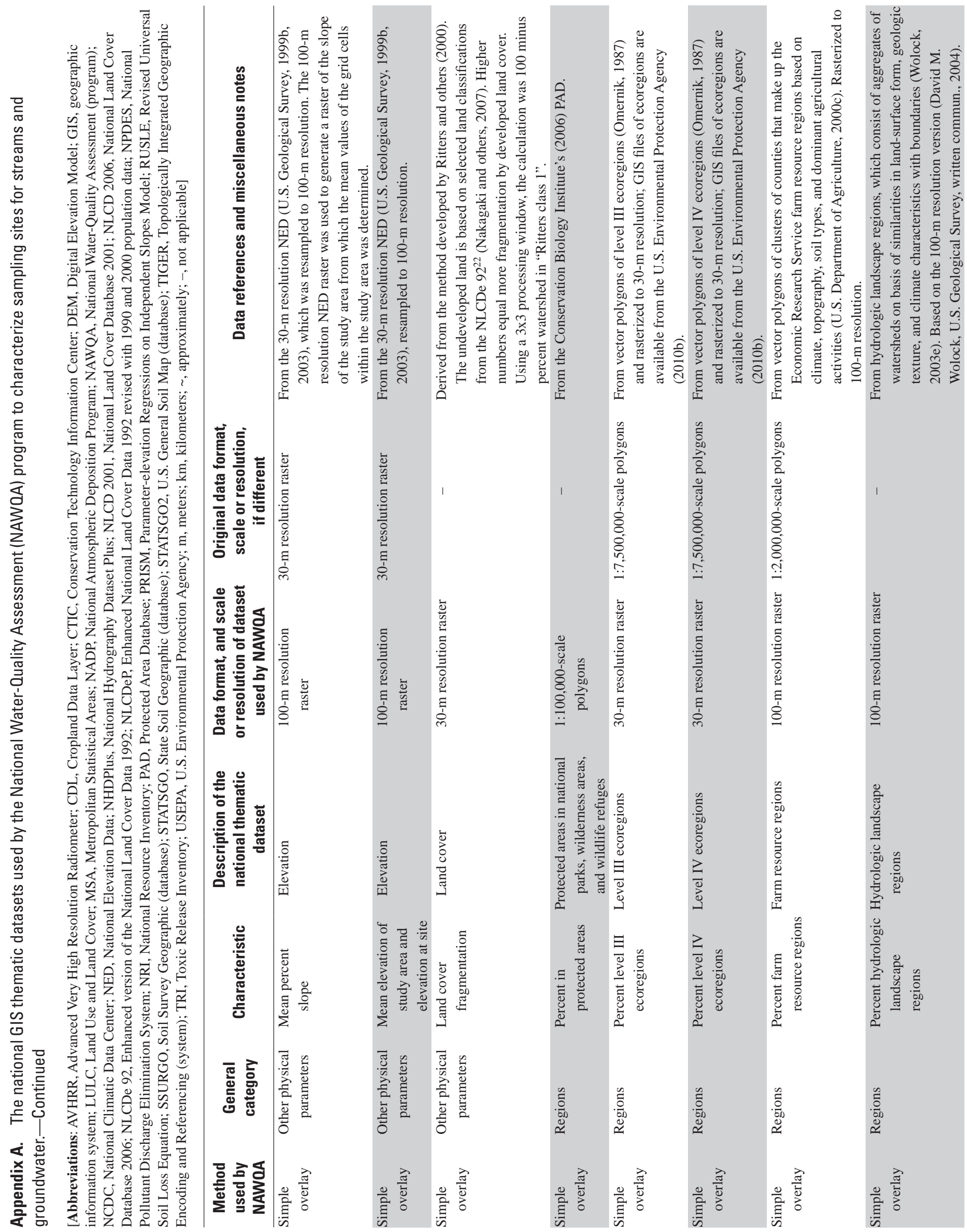




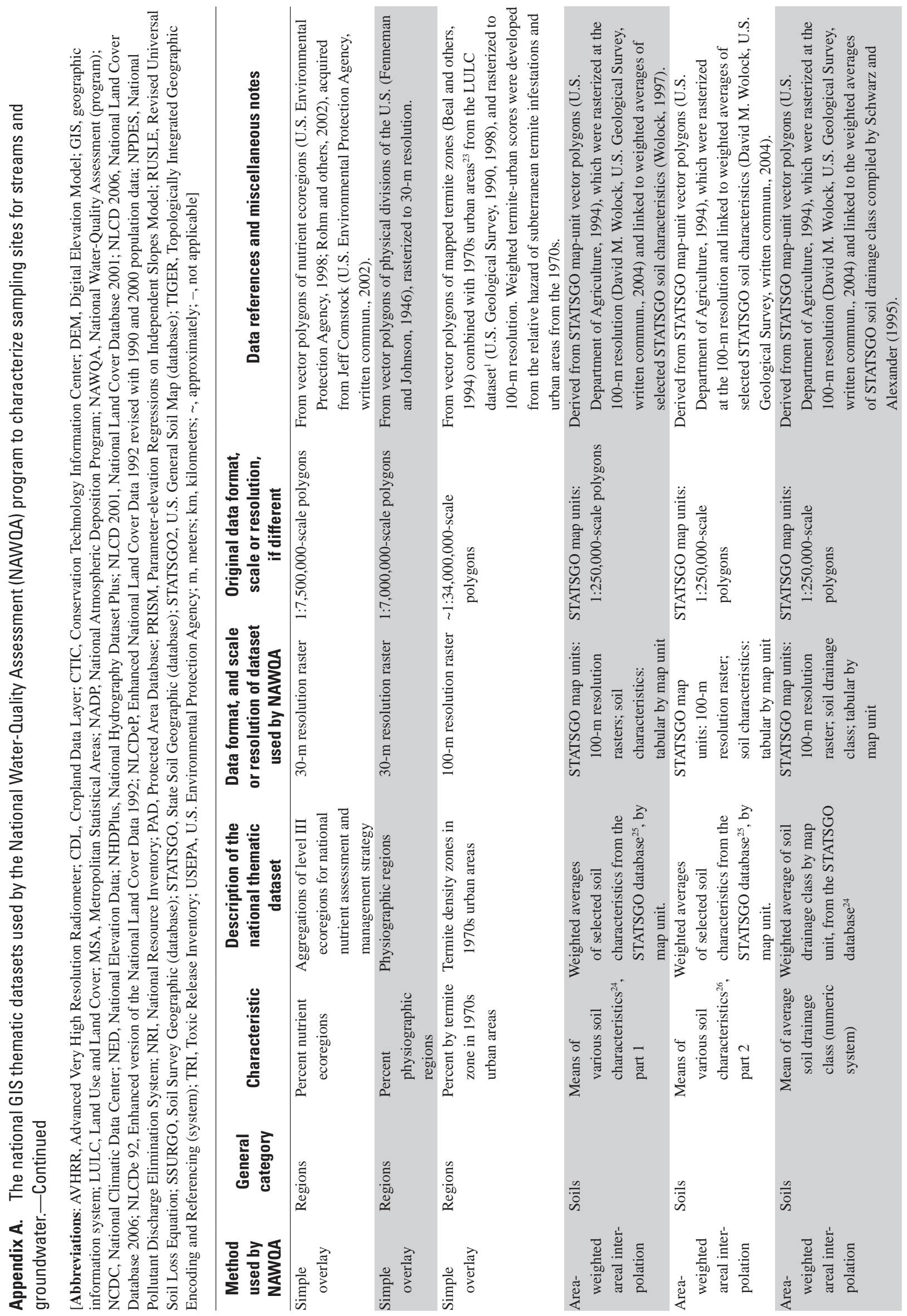




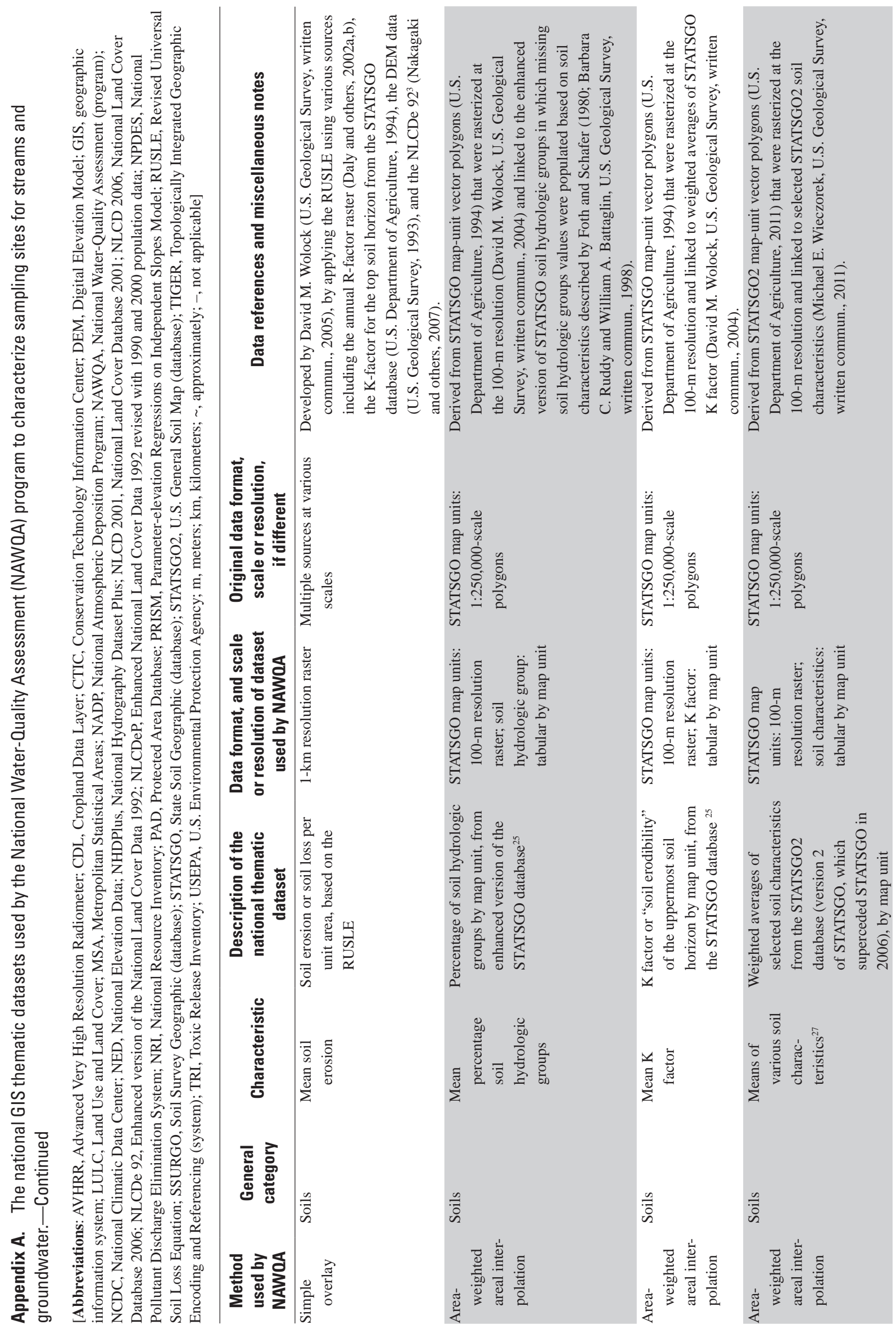



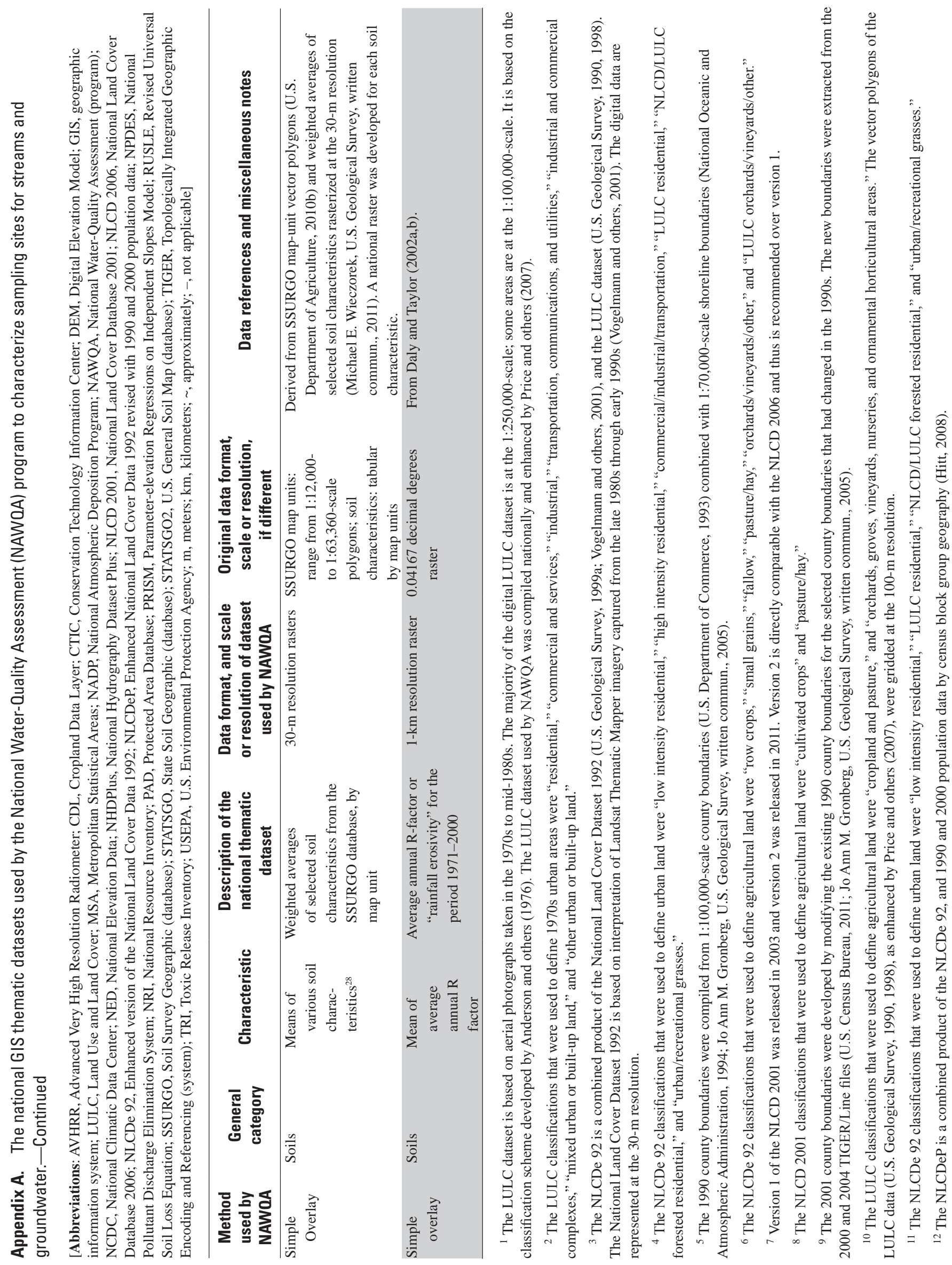


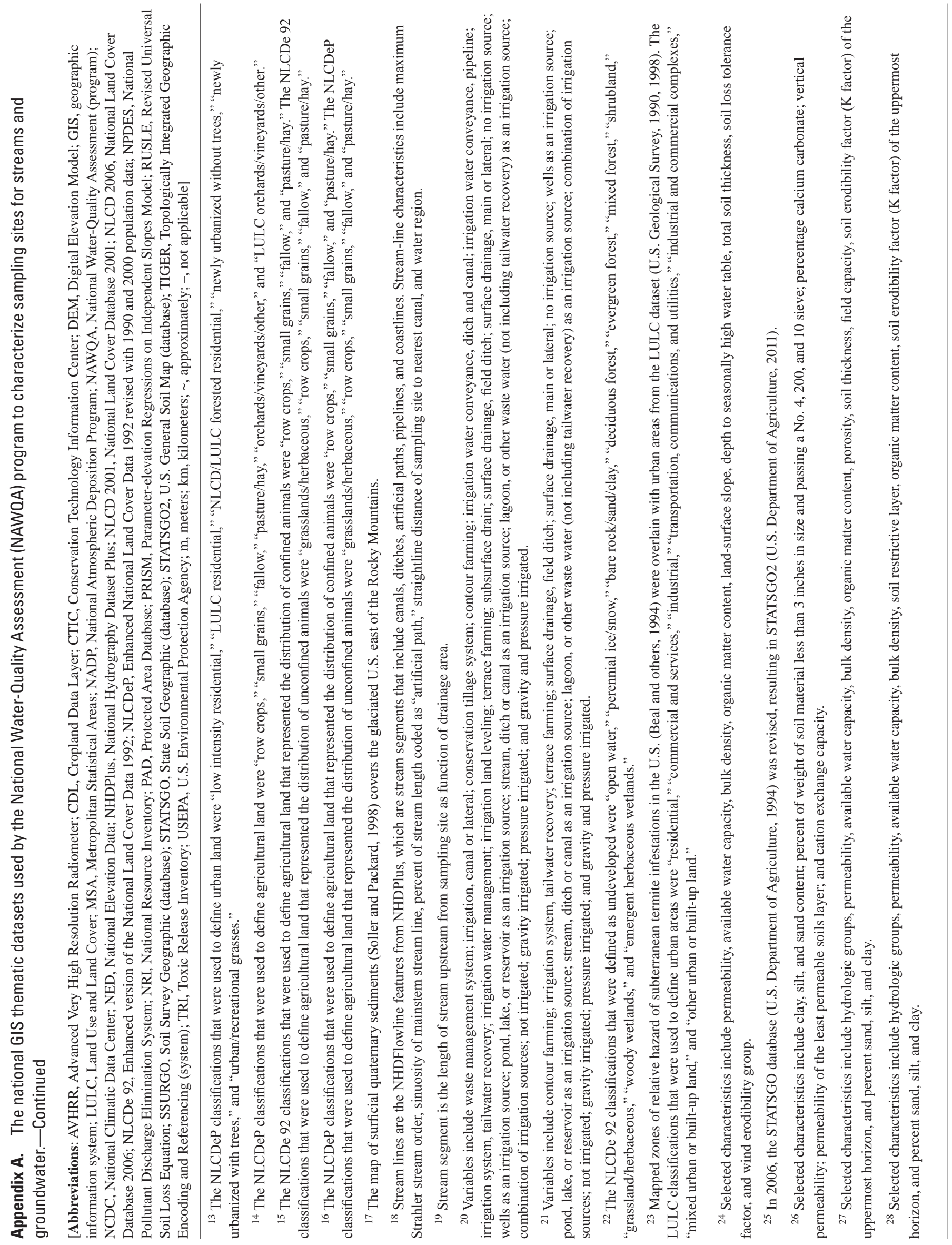




\section{References Cited}

Anderson, J.R., Hardy, E.E., Roach J.T., and Witmer R.E., 1976, A land use and land cover classification system for use with remote sensor data: U.S. Geological Survey Professional Paper 964, 28 p.

Baker, N.T., 2011, Tillage practices in the conterminous United States, 1989-2004_Datasets aggregated by watershed: U.S. Geological Survey Data Series 573, 13 p.

Beal, R.H., Mauldin, J.K., and Jones, S.C., 1994, Subterranean termites-their prevention and control in buildings: U.S. Department of Agriculture, Home and Garden Bulletin no. 64.

Beven, K.J., and Kirkby, M.J., 1979, A physically based, variable contributing area model of basin hydrology: Hydrological Sciences Bulletin, v. 24, p. 43-69.

Clawges, R.M., and Price, C.V., 1999a, Digital data set describing surficial geology in the conterminous United States: U.S. Geological Survey Open-File Report 99-77, accessed April 2003, at http://water.usgs.gov/lookup/ getspatial?ofr99-77 geol75m.

Clawges, R.M., and Price, C.V., 1999b, Digital data set describing principal aquifers in the conterminous United States: U.S. Geological Survey Open-File Report 99-77, accessed April 2003, at http://water.usgs.gov/lookup/ getspatial?ofr99-77 aquif75m.

Climate Source, Inc., 2006, Spatial climate products: Climate Source, accessed November 2006, at http://www. climatesource.com/products.html.

Conservation Biology Institute, 2006, Protected areas database: Conservation Biology Institute, accessed February 2006, currently at http://consbio.org.

Consortium for International Earth Science Information Network (CIESIN), 1995, Socioeconomic Data and Applications Center (SEDAC) archive of census related products: National Aeronautics and Space Administration (NASA) SEDAC, accessed July 21, 1998, at http://sedac. ciesin.org/plue/cenguide.html.

Daly, C., Gibson, W.P., Taylor, G.H., Johnson, G.L., and Pasteris, P., 2002, A knowledge-based approach to the statistical mapping of climate: Climate Research, v. 22, p. 99-113.

Daly, C., and Taylor, G.H., 2002a, Development of new spatial grids of R-factor and 10-yr EI30 for the conterminous United States-Final Report: U.S. Environmental Protection Agency, Las Vegas, Nev., 38 p.
Daly, C., and Taylor, G.H., 2002b, United States mean annual R-factor, 1971-2000: Oregon State University digital raster data, accessed November 2010, at http://prism.nacse.org/ pub/prism/maps/Precipitation/rfactor/U.S./us maps.html.

Fenneman, N.M., and Johnson, D.W., 1946, Physiographic divisions of the conterminous United States: U.S. Geological Survey Map, scale 1:7,000,000, digital vector data accessed January 2002, at http://water.usgs.gov/lookup/ getspatial?physio.

Foth, H.D., and Schafer J.W., 1980, Soil geography and land use: John Wiley and Sons, Inc., New York, N.Y., 484 p.

Fry, J.A., Coan, M.J., Homer, C.G., Meyer, D.K., and Wickham, J.D., 2009, Completion of the national land cover database (NLCD) 1992-2001 land cover change retrofit product: U.S. Geological Survey Open-File Report 2008-1379, 18 p.

Fry, J.A., Xian, G., Jin, S., Dewitz, J.A., Homer, C.G., Yang, L., Barnes, C.A., Herold, N.D., and Wickham, J.D., 2011, Completion of the 2006 national land cover database for the conterminous United States: Photogrammetric Engineering and Remote Sensing, v. 77, no. 9, p. 858-864.

Gebert, W.A., Graczyk, D. J., and Krug, W. R., 1987, Average annual runoff in the United States, 1951-80: U.S. Geological Survey Hydrologic Investigations Atlas HA-710, scale 1:7,500,000, accessed February 2003, at http://water.usgs.gov/lookup/getspatial?runoff.

GeoLytics, Inc., 2001a, CensusCD 2000/Short form blocks: GeoLytics, East Brunswick, N.J. [digital data on CD-ROM].

GeoLytics, Inc., 2001b, Census 2000 and street 2000: GeoLytics, East Brunswick, N.J. [digital data on 2 CD-ROMs].

Gilliom, R.J., and Thelin, G.P., 1997, Classification and mapping of agricultural land for National Water-Quality Assessment: U.S. Geological Survey Circular 1131, 70 p.

Hamon, W.R., 1961, Estimating potential evapotranspiration: Journal of the Hydraulics Division, Proceedings of the American Society of Civil Engineers, v. 87, p. 107-120.

Hitt, K.J., 1992, 1990 point population coverage for the conterminous United States: U.S. Geological Survey digital vector data, accessed February 15, 2005, at http://water. usgs.gov/lookup/getspatial?uspop90.

Hitt, K.J., 2003, 2000 population density by block group for the conterminous United States: U.S. Geological Survey digital raster data, accessed December 2005, at http://water. usgs.gov/lookup/getspatial?uspopd00x10g. 
Hitt, K.J., 2008, Enhanced national land cover data 1992 revised with 1990 and 2000 population data to indicate urban development between 1992 and 2000 (NLCDep0306): U.S. Geological Survey digital raster data, accessed December 2009, at http://water.usgs.gov/lookup/ getspatial?nlcdep0306.

Homer, C.G., Dewitz, J., Fry, J.A., Coan, M.J., Hossain, N.D., Larson, C.R., Herold, N., McKerrow, A., VanDriel, J.N., and Wickman, J.D., 2007, Completion of the 2001 national land cover database for the conterminous United States: Photogrammetric Engineering and Remote Sensing, v. 73, no. 4, p. 337-341.

Hunt, C. D., 1979, National atlas of the United States of America-Surficial geology: U.S. Geological Survey, NAC-P-0204-75M-O [map].

Johnson, D.M., and Mueller, R., 2010, The 2009 cropland data layer: Photogrammetric Engineering and Remote Sensing, v. 76, no. 11, pp. 1201-1205.

King, P. B., and Beikman, H.M., 1974a, Explanatory text to accompany the geologic map of the United States: U.S. Geological Survey Professional Paper 901, 40 p.

King, P. B., and Beikman, H.M., 1974b, Geologic map of the United States (exclusive of Alaska and Hawaii) on a scale of 1:2,500,000: U.S. Geological Survey, 3 color plates.

Krug, W.R., Gebert, W.A., and Graczyk, D.J., 1989, Preparation of average annual runoff map of the United States, 1951-80: U.S. Geological Survey Open-File Report 87-535, 414 p.

LaMotte, A.E., 2008a, National land cover database 2001 (NLCD01) tile 1, northwest United States: NLCD01_1: U.S. Geological Survey Data Series 383A, accessed October 2008, at http://water.usgs.gov/lookup/ getspatial?nlcd01 1.

LaMotte, A.E., 2008b, National land cover database 2001 (NLCD01) tile 2, northeast United States: NLCD01_2: U.S. Geological Survey Data Series 383B, accessed October 2008, at http://water.usgs.gov/lookup/ getspatial?nlcd01_2.

LaMotte, A.E., 2008c, National land cover database 2001 (NLCD01) tile 3, southwest United States: NLCD01_3: U.S. Geological Survey Data Series 383C, accessed October 2008, at http://water.usgs.gov/lookup/ getspatial?nlcd01 3.

LaMotte, A.E., 2008d, National land cover database 2001 (NLCD01) tile 4, southeast United States: NLCD01_4: U.S. Geological Survey Data Series 383D, accessed October 2008, at http://water.usgs.gov/lookup/ getspatial?nlcd01 4.
Nakagaki, Naomi, 2007a, Grids of agricultural pesticide use in the conterminous United States, 1992: U.S. Geological Survey digital raster data, accessed August 29, 2007, at http://water.usgs.gov/lookup/getspatial?agpest92grd.

Nakagaki, Naomi, 2007b, Grids of agricultural pesticide use in the conterminous United States, 1997: U.S. Geological Survey digital raster data, accessed August 29, 2007, at http://water.usgs.gov/lookup/getspatial?agpest97grd.

Nakagaki, Naomi, Price, C.P., Falcone, J.A., Hitt, K.J., and Ruddy, B.C., 2007, Enhanced national land cover data 1992 (NLCDe 92): U.S. Geological Survey digital raster data, accessed December 1, 2007, at http://water.usgs.gov/ lookup/getspatial?nlcde92.

National Atmospheric Deposition Program, 2002, National Atmospheric Deposition Program 2001 annual summaryNADP Data Report 2002-01: Illinois State Water Survey, Champaign, Ill.

National Atmospheric Deposition Program, 2005, National Atmospheric Deposition Program 2004 annual summaryNADP Data Report 2005-01: Illinois State Water Survey, Champaign, Ill.

National Climatic Data Center, 1991, Climate divisions (ed. 1.1): U.S. Geological Survey digital vector data, accessed December 11, 2002, at http://water.usgs.gov/ lookup/getspatial?climate_div.

National Climatic Data Center, 2007, Time bias corrected divisional temperature-precipitation-drought index (TD9640) [digital data files], currently at http://www.ncdc.noaa. gov/oa/climate/climateinventories.html.

National Oceanic and Atmospheric Administration, 1994, NOS80K/ALLUS80K medium-resolution digital vector U.S. shoreline shapefile: National Oceanic and Atmospheric Administration (NOAA), National Ocean Service, Office of Coast Survey and the Strategic Environmental Assessments Division of the Office of Ocean Resources Conservation and Assessment, accessed August 2005, currently at http:// woodshole.er.usgs.gov/pubs/of2005-1048/data/basemaps/ usa/nos $80 \mathrm{k} /$ nos $80 \mathrm{k} . \mathrm{htm}$.

National Oceanic and Atmospheric Administration, 2006, Impervious surface area of the United States: National Oceanic and Atmospheric Administration, National Geophysical Data Center, accessed July 2006 at http://dmsp. ngdc.noaa.gov/html/download isa2000 2001.html.

Omernik, J.M., 1987, Ecoregions of the conterminous United States. Map (scale 1:7,500,000): Annals of the Association of American Geographers v. 77, no. 1, p.118-125. 
Owensby, J.R., and Ezell, D.S., 1992, Climatography of the United States, No. 81-Monthly station normals of temperature, precipitation, and heating and cooling degree days, 1961-90: U.S. Department of Commerce, National Oceanic and Atmospheric Administration, National Climatic Data Center, Ashville, N.C.

Price, C.V., 2003, 1990 Population density by block group for the conterminous United States: U.S. Geological Survey digital raster data, accessed January 24, 2005, at http:// water.usgs.gov/lookup/getspatial?uspopd90x10g.

Price, C.V., and Clawges, R.M., 1999a, Digital data sets describing population density in the conterminous United States: U.S. Geological Survey Open-File Report 99-78, accessed May 5, 1999, at http://water.usgs.gov/lookup/ getspatial?ofr99-78_popdeng.

Price, C.V., and Clawges, R.M., 1999b, Digital data sets describing metropolitan areas in the conterminous United States: U.S. Geological Survey Open-File Report 99-78, accessed May 4, 1999, at http://water.usgs.gov/lookup/ getspatial?ofr99-78 metropop.

Price, C.V., and Clawges, R.M., 1999c, Digital data sets describing toxics release inventory locations with 1995 VOC releases in the conterminous United States: U.S. Geological Survey Open-File Report 99-78, accessed September 27, 2010, at http://water.usgs.gov/lookup/ getspatial?ofr99-78 eftri.

Price, C.V., Nakagaki, N., Hitt, K.J., and Clawges, R.M., 2007, Enhanced historical land-use and land-cover data sets of the U.S. Geological Survey: U.S. Geological Survey Data Series 240, accessed August 29, 2007, at http://pubs.usgs. gov/ds/2006/240.

PRISM Climate Group, 2010, Parameter-elevation regressions on independent slopes model (PRISM): PRISM Climate Group, Oregon State University, accessed November 16, 2010, at http://www.prism.oregonstate.edu/.

Radeloff, V. C., Hammer, R. B., Stewart, S. I., Fried, J.S., Holcomb, S. S., and McKeefry, J. F., 2005, The wildland urban interface in the United States: Ecological Applications, v. 15, p. 799-805.

Reed, J.C., and Bush, C.A., 2005, Generalized geologic map of the United States, Puerto Rico, and the U.S. Virgin Islands (ver. 2.0), posted December 2005, accessed September 28, 2010, at http://pubs.usgs.gov/atlas/geologic/.

Ritters, K., Wickham, J., O'Neill, R., Jones, B., and Smith, E., 2000, Global-scale patterns of forest fragmentation: Conservation Ecology, v. 4, no. 2, art. 3.
Rohm, C.M., Omernik, J.M., Woods, A.J., and Stoddard, J.L., 2002, Regional characteristics of nutrient concentrations in streams and their application to nutrient criteria development: Journal of the American Water Resources Association, v. 38, no. 1, p. 1-27.

Ruddy, B.C., Lorenz, D.L., and Mueller, D.K., 2006, Countylevel estimates of nutrient inputs to the land surface of the conterminous United States, 1982-2001: U.S. Geological Survey Scientific Investigations Report 2006-5012, 17 p.

Schruben, P. G., Arndt, R.E., and Bawiec, W.J., 1998 (release 2), Geology of the conterminous United States at 1:2,500,000 scale-A digital representation of the 1974 P.B. King and H.M. Beikman Map: U.S. Geological Survey Digital Data Series, DDS-11, accessed June 1999, at http:// pubs.usgs.gov/dds/dds11.

Schwarz, G.E., and Alexander, R.B., 1995, Soils data for the conterminous United States derived from the NRCS state soil geographic (STATSGO) data base [Original title: State soil geographic (STATSGO) data base for the conterminous United States.]: U.S. Geological Survey Open-File Report 95-449, accessed June 2002, at http://water.usgs.gov/ lookup/getspatial?ussoils.

SILVIS Laboratory, 2007, Spatial analysis of conservation and sustainability: SILVIS Laboratory, University of Wisconsin at Madison, Wis., accessed March 2007, at http://www. silvis.forest.wisc.edu/old/maps.php.

Soller, D.R., and Packard, P.H., 1998, Digital representation of a map showing the thickness and character of quaternary sediments in the glaciated United States east of the Rocky Mountains: U.S. Geological Survey Digital Data Series DDS-38, accessed April 16, 2007, at http://pubs.usgs.gov/ dds/dds38.

Solley, W.B., Pierce, R.R., and Perlman, H.A., 1998, Estimated use of water in the United States in 1995: U.S. Geological Survey Circular 1200, 71 p., accessed December 10, 2007, at http://water.usgs.gov/watuse/ pdf1995/html/.

Steeves, P.A., and Nebert, D.D., 1994, Hydrologic unit maps of the conterminous United States: U.S. Geological Survey digital vector data, accessed January 27, 2005, at http:// water.usgs.gov/lookup/getspatial?huc $250 \mathrm{k}$.

Thelin, G.P., 2005a, 1992 County pesticide use estimates for 200 compounds (ver. 2.0): U.S. Geological Survey digital file, accessed October 27, 2005, at http://water.usgs.gov/ lookup/getspatial?pesticide use92.

Thelin, G.P., 2005b, 1997 County pesticide use estimates for 220 compounds (ver. 2.0): U.S. Geological Survey digital file, accessed October 27, 2005, at http://water.usgs.gov/ lookup/getspatial?pesticide use97. 
Thelin, G.P., 2010, Annual county atrazine use estimates for agriculture (ver. 1.1): U.S. Geological Survey digital tabular data, accessed September 22, 2010, at http://water.usgs.gov/ lookup/getspatial?sir2010-5034.

Thorton, P.E., and Running, S.W., 1999, An improved algorithm for estimating incident daily solar radiation from measurements of temperature, humidity, and precipitation: Agricultural and Forest Meteorology, v. 93, p. 211-228.

University of Montana, 2005, Daymet, Daily surface weather and climatological summaries: Numerical Terradynamic Simulation Group, Daymet database, accessed August 2005, currently at http://daymet.ornl.gov.

U.S. Army Corps of Engineers, 2006, National inventory of dams: U.S. Army Corps of Engineers, digital data retrieved July 2006, currently at http://nid.usace.army.mil.

U.S. Bureau of the Census, 1992, Census of population and housing, 1990 - Summary Tape file 3A: U.S. Bureau of the Census, Washington, D.C.

U.S. Bureau of the Census, 2001a, 1990 Census block group cartographic boundary files (rev. 4/22/05): U.S. Census Bureau, Geography Division, digital vector data, accessed October 25, 2007, at http://www.census.gov/geo/www/cob/ bg1990.html.

U.S. Bureau of the Census, 2001b, 2000 Census block group cartographic boundary files (rev. 4/22/05): U.S. Census Bureau, Geography Division, digital vector data, accessed October 25, 2007, at http://www.census.gov/geo/www/cob/ bg2000.html.

U.S. Census Bureau, 2011, TIGER/Line Shapefiles and TIGER/Line Files: U.S. Census Bureau, Geography Division, digital vector data, accessed November 14, 2011, at http://www.census.gov/geo/www/tiger/shp.html.

U.S. Department of Agriculture, 1994, State soil geographic (STATSGO) database - data use informationMiscellaneous publication no. 1492 (rev. ed.): Fort Worth, Texas, Natural Resources Conservation Service [variously paged].

U.S. Department of Agriculture, 1995, 1992 National Resources Inventory: Natural Resources Conservation Service, Washington, D.C., and Statistical Laboratory, Iowa State University, Ames, Iowa [CDROM].

U.S. Department of Agriculture, 1999, 1997 Census of agriculture, Geographic area series 1A, 1B, 1C, Washington, DC., U.S. summary and county level data file: U.S. Department of Agriculture (USDA), National Agricultural Statistics Service (NASS) [producer and distributor, CD$\mathrm{ROM}]$.
U.S. Department of Agriculture, 2000a (Reissued 2001), 1997 National Resources Inventory: Natural Resources Conservation Service, Washington, DC, and Statistical Laboratory, Iowa State University, Ames, Iowa [CD-ROM].

U.S. Department of Agriculture, 2000b, Summary Report: 1997 National Resources Inventory (rev. December 2000): Natural Resources Conservation Service, Washington, DC, and Statistical Laboratory, Iowa State University, Ames, Iowa, $89 \mathrm{p}$.

U.S. Department of Agriculture, 2000c, Farm resource regions: U.S. Department of Agriculture, Economic Research Service, Agricultural Information Bulletin Number 760, accessed January 11, 2002, currently at http://webarchives.cdlib.org/wayback.public/UERS ag_1/20111128195215/http:/www.ers.usda.gov/Briefing/ ARMS/resourceregions/resourceregions.htm.

U.S. Department of Agriculture, 2004, 2002 Census of Agriculture, Geographic area series, 1A and 1B, Washington, DC, U.S. summary and county level data file: U.S. Department of Agriculture, National Agricultural Statistics Service (NASS) [producer and distributor, CDROM].

U.S. Department of Agriculture, 2009, 2007 Census of Agriculture: National Agricultural Statistics Service, accessed January 7, 2009, at http://www.agcensus.usda. gov/.

U.S. Department of Agriculture, 2010a, 2009 Cropland Data Layer: National Agricultural Statistics Service, accessed December 30, 2011, at http:// www.nass.usda.gov/research/ Cropland/SARS1a.htm.

U.S. Department of Agriculture, 2010b, Soil survey geographic (SSURGO) database: Soil Survey Staff, Natural Resources Conservation Service, accessed October 18, 2010, at http://soildatamart.nrcs.usda.gov.

U.S. Department of Agriculture, 2011, U.S. general soil map (STATSGO2) database: Soil Survey Staff, Natural Resources Conservation Service, accessed February 24, 2012, at http://soils.usda.gov/survey/geography/statsgo.

U.S. Department of Commerce, 1993, Bureau of the Census, 1:100,000-scale counties of the United States (ed. 1.1): U.S. Geological Survey digital vector data, accessed August 21, 2003, at http://water.usgs.gov/lookup/getspatial?county100.

U.S. Department of Commerce, 1995, 1992 Census of agriculture, geographic area series $1 \mathrm{~A}$ and $1 \mathrm{~B}$, U.S. summary and county level state data: Bureau of the Census, Washington, DC [CD-ROM]. 
U.S. Environmental Protection Agency, 1998, National strategy for the development of regional nutrient criteria: U.S. Environmental Protection Agency Office of Water, Washington, D.C., 882-R-98-002, 47 p.

U.S. Environmental Protection Agency, 2006, National pollutant discharge elimination system (NPDES): U.S. Environmental Protection Agency, accessed June 2006, at http://cfpub.epa.gov/npdes/.

U.S. Environmental Protection Agency, 2008, National hydrography dataset plus (NHDPlus): U.S. Environmental Protection Agency, U.S. Geological Survey, and Horizon Systems Corporation, accessed October 2008, at http:// www.horizon-systems.com/nhdplus.

U.S. Environmental Protection Agency, 2010a, Toxic release inventory (TRI) program fact sheet: U.S. Environmental Protection Agency, accessed October 2010, currently at http://www.epa.gov/tri/triprogram/TRI factsheeet Jan 2012.pdf.

U.S. Environmental Protection Agency, 2010b, Level III and IV ecoregions of the continental United States: U.S. Environmental Protection Agency, Western Ecology Division, accessed November 15, 2010, at http://www.epa. gov/wed/pages/ecoregions/level iii.htm.

U.S. Geological Survey, 1970, The national atlas of the United States of America, Washington, D.C., U.S. Government Printing Office, $417 \mathrm{p}$.

U.S. Geological Survey, 1990, Land use and land cover digital data from 1:250,000- and 1:100,000-scale maps: U.S. Geological Survey Data User Guide, no. 4, 25 p.

U.S. Geological Survey, 1993, Digital elevation models—data users guide 5: Reston, Va., U.S. Geological Survey, 48 p.

U.S. Geological Survey, 1998, Land use and land cover digital data from 1:250,000- and 1:100,000-scale maps: U.S. Geological Survey, Earth Resources Observation and Science Center, accessed January 1, 2003, at http://edcwww. cr.usgs.gov/products/landcover/lulc.html.

U.S. Geological Survey, 1999a, National land cover data 1992, accessed June 16, 2005, currently at http://www.mrlc.gov/ nlcd92 data.php.

U.S. Geological Survey, 1999b, National elevation dataset (NED): U.S. Geological Survey Fact Sheet 148-99, accessed November 16, 2007, at http://erg.usgs.gov/isb/ pubs/factsheets/fs14899.pdf.

U.S. Geological Survey, 2001, Elevation Program: U.S. Geological Survey Rocky Mountain Mapping Center, accessed September 28, 2010, at http://rmmcweb.cr.usgs. gov/.
U.S. Geological Survey, 2003, National elevation data set (NED), accessed April 2003, currently at http://nationalmap. gov/elevation.html.

U.S. Geological Survey, 2007a, National land cover database 2001, accessed May 25, 2007, at http://www.mrlc.gov/ mrlc2k nlcd.asp.

U.S. Geological Survey, 2007b, National land cover database (NLCD) 1992/2001 retrofit land cover change product multi-zone download, accessed December 11, 2007, at http://www.mrlc.gov/mrlc2k multizone.asp.

U.S. Geological Survey, 2011, National land cover database 2006 (NLCD 2006), accessed April 2011, at http://www. mrlc.gov/nlcd06 data.php.

U.S. Geological Survey, 2012, Water Watch --Past streamflow conditions, accessed November 6, 2012, at http:// waterwatch.usgs.gov/?id-romap3.

U.S. Geological Survey and U.S. Environmental Protection Agency, 2010, NHDPlus user guide (ver. September 1, 2010): Horizon Systems, accessed September 24, 2010, currently at ftp://ftp.horizon-systems.com/NHDPlusV1/ Documentation/NHDPLUSV1 UserGuide.pdf.

Verdin, K.L., and Greenlee, S.K., 1996, Development of continental scale digital elevation models and extraction of hydrographic features. In: Proceedings, Third International Conference/Workshop on Integrating GIS and Environmental Modeling, Santa Fe, New Mexico, January 21-26,1996, National Center for Geographic Information and Analysis, Santa Barbara, Calif. [CD-ROM].

Vista Information Solutions, 1999, StarView real estate user's guide (ver. 2.6.1): Vista Information Solutions, San Diego, Calif., 228 p.

Vogelmann, J.E., Howard, S.M., Yang, L., Larson, C.R., Wylie, B.K., and Van Driel, N., 2001, Completion of the 1990's national land cover data set for the conterminous United States from Landsat Environmental Mapper data and ancillary data sources: Photogrammetric Engineering and Remote Sensing, v. 67, p. 650-662.

Williams, C. N., Menne, M. J., Vose, R. S., and Easterling, D.R., 2006, United States historical climatology network daily temperature, precipitation, and snow data, ORNL/ CDIAC-118, NDP-070: Carbon Dioxide Information Analysis Center, Oak Ridge National Laboratory, Oak Ridge, Tennessee, accessed November 16, 2010, at http:// cdiac.ornl.gov/epubs/ndp/ushcn/ndp070.html.

Wolock, D.W., 1997, STATSGO soil characteristics for the conterminous United States: U.S. Geological Survey OpenFile Report 97-656, accessed March 14, 2001, at http:// water.usgs.gov/lookup/getspatial?muid. 
Wolock, D.M., 2003a, Base-flow index grid for the United States: U.S. Geological Survey Open-File Report 03-263, accessed September 9, 2005, at http://water.usgs.gov/ lookup/getspatial?bfi48grd.

Wolock, D.M., 2003b, Saturation overland flow estimated by TOPMODEL for the conterminous United States: U.S. Geological Survey Open-File Report 03-264, accessed April 16, 2007, at http://water.usgs.gov/lookup/ getspatial?satof48.

Wolock, D.M., 2003c, Estimated mean annual natural groundwater recharge in the conterminous United States: U.S. Geological Survey Open-File Report 03-311, accessed April 16, 2007, at http://water.usgs.gov/lookup/ getspatial?rech48grd.
Wolock, D.M., 2003d, Infiltration-excess overland flow estimated by TOPMODEL for the conterminous United States: U.S. Geological Survey Open-File Report 03-310, accessed April 16, 2007, at http://water.usgs.gov/lookup/ getspatial?ieof48.

Wolock, D.M., 2003e, Hydrologic landscape regions of the United States: U.S. Geological Survey Open-File Report 03-145, accessed December 3, 2004, at http://water.usgs. gov/lookup/getspatial?hlrus.

Wolock, D.M., and McCabe, G.J., 1995, Comparison of single and multiple flow direction algorithms for computing topographic parameters in TOPMODEL: Water Resources Research, v. 31, p.1315-1324. 
Publishing support provided by the U.S. Geological Survey Science Publishing Network, Menlo Park, Sacramento and Tacoma Publishing Service Centers

For more information concerning the research in this report, contact the Director, California Water Science Center

U.S. Geological Survey

6000 J Street, Placer Hall

Sacramento, California 95819

http://ca.water.usgs.gov 


\section{趈}

